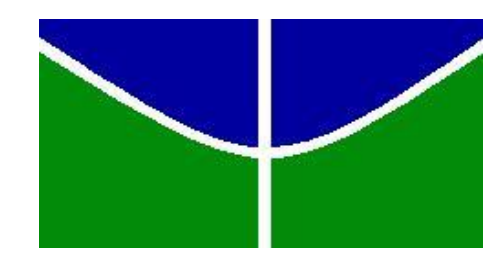
Universidade de Brasília - UnB
Instituto de Letras - IL

Departamento de Linguística, Português e Línguas Clássicas - LIP

Programa de Pós-Graduação em Linguística - PPGL

\title{
A funcionalidade do sufixo - a em línguas Tupí-Guaraní
}

Karine Dourado Silva

Orientadora: Prof ${ }^{\mathrm{a}}$. Dra. Walkíria Neiva Praça

Brasília-DF 


$$
\begin{gathered}
\text { Universidade de Brasília - UnB } \\
\text { Instituto de Letras - IL }
\end{gathered}
$$

Departamento de Linguística, Português e Línguas Clássicas - LIP

Programa de Pós-Graduação em Linguística - PPGL

\section{A funcionalidade do sufixo -a em línguas Tupí-Guaraní}

Karine Dourado Silva

Dissertação apresentada ao Programa de PósGraduação em Linguística, Departamento de Linguística, Português e Línguas Clássicas, Instituto de Letras, Universidade de Brasília, como requisito parcial para obtenção do título de Mestra em Linguística, área de concentração Teoria e Análise Linguística.

Brasília - DF 
Universidade de Brasília - UnB

Instituto de Letras - IL

Departamento de Linguística, Português e Línguas Clássicas - LIP

Programa de Pós-Graduação em Linguística - PPGL

Dissertação de mestrado

\section{A funcionalidade do sufixo - a em línguas Tupí-Guaraní}

Karine Dourado Silva

Orientadora: Prof ${ }^{a}$. Dra. Walkíria Neiva Praça

Banca examinadora:

Prof ${ }^{a}$. Dr ${ }^{\mathrm{a}}$. Walkíria Neiva Praça (UnB) (presidente)

Prof $^{a}$. Dr ${ }^{\mathrm{a}}$. Marina Maria Silva Magalhães (UnB)

Prof $^{\mathrm{a}}$. Dr ${ }^{\mathrm{a}}$. Mônica Veloso Borges (UFG)

Prof $^{\mathrm{a}}$. Dr ${ }^{\mathrm{a}}$. Flávia de Castro Alves (UnB) (suplente) 
Ficha catalográfica elaborada automaticamente, com os dados fornecidos pela autora.

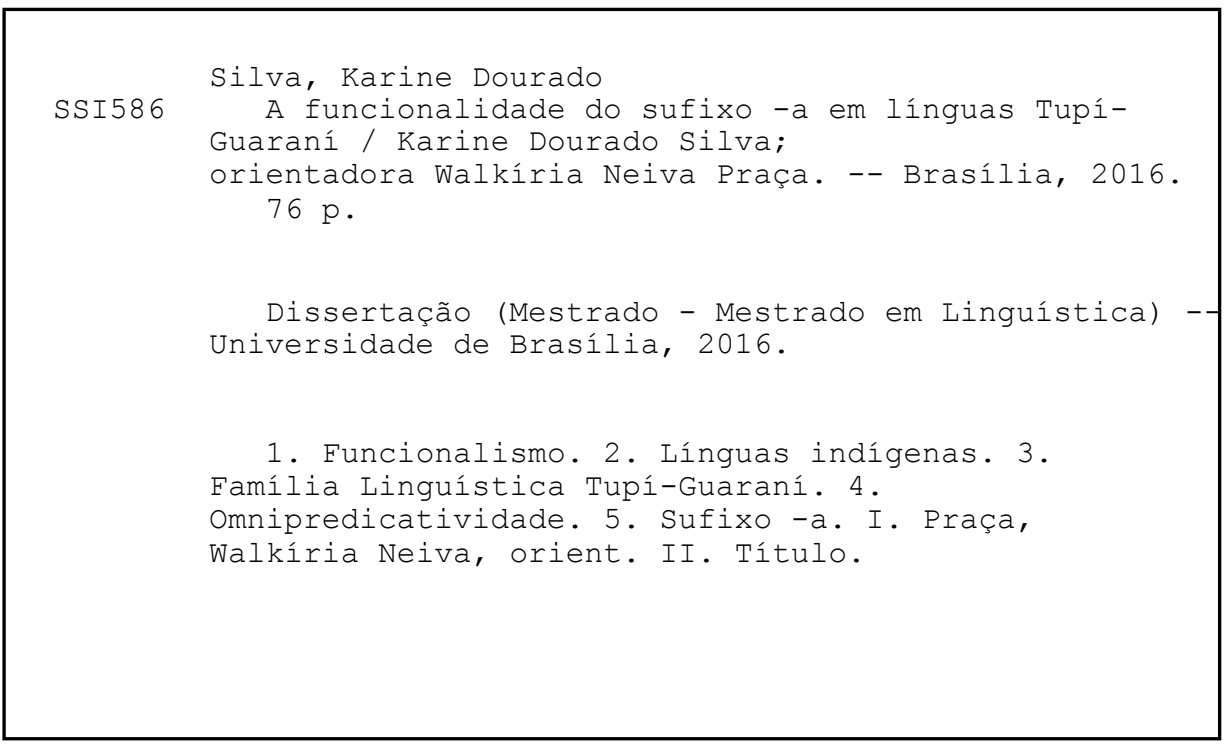




\section{A funcionalidade do sufixo - $a$ em línguas Tupí-Guaraní}

Karine Dourado Silva

Dissertação apresentada ao Programa de Pós-Graduação em Linguística, Departamento de Linguística, Português e Línguas Clássicas, Instituto de Letras, Universidade de Brasília, como requisito parcial para obtenção do título de Mestra em Linguística, área de concentração Teoria e Análise Linguística.

\section{COMISSÃO EXAMINADORA}

Professora Doutora Walkíria Neiva Praça (Orientadora/presidente - UnB)

Professora Doutora Marina Maria Silva Magalhães (Membro efetivo interno - UnB)

Professora Doutora Mônica Veloso Borges (Membro efetivo externo - UnB)

Professora Doutora Flávia de Castro Alves (Membro suplente - UnB) 
Dedico este trabalho às comunidades indígenas do Brasil, exemplos de força $e$ perseverança na luta pela sobrevivência. 
“(...)

Lá fora muitos homens querem esconder a verdadeira força que eu posso ter privando minha mente de evoluir assim fica mais fácil de me distrair."

“Não chore meu amor”, Natiruts. 


\section{Agradecimentos}

À Força Superior, por me possibilitar existir, aprender e compreender que o maior conhecimento vem do estudo de si.

Ao Programa de Pós-Graduação em Linguística - PPGL e à Coordenação de Aperfeiçoamento de Pessoal de Ensino Superior - Capes, pelo investimento acadêmico e financeiro que me foi garantido.

À Universidade de Brasília, por me proporcionar momentos eternamente saudosos.

Aos povos Tapirapé, Guajá, Kamaiurá, entre outros citados neste trabalho, pela generosidade de um dia terem recebido pesquisadores em suas comunidades e, consequentemente, possibilitarem hoje a elaboração desta pesquisa bibliográfica.

À minha orientadora, Prof ${ }^{a}$. Dra . Walkíria Neiva Praça, por ter me iniciado nos estudos das línguas indígenas e ter me auxiliado nesta caminhada de desafios e descobertas.

Aos queridos professores da graduação e da pós-graduação, por me apresentarem as questões de línguas com tanto compromisso e entusiasmo.

Aos professores do NTL, pelos enriquecedores encontros de compartilhamento, aprendizado e apoio.

Aos meus familiares, por serem diferentes uns dos outros e, inclusive, de mim.

Aos meus pais, Maria Rosa da Silva e Robinson Ferreira da Silva, por serem fonte infinita de amor e me ensinarem o valor da fé.

À Cristiane Torido Serra, pela parceria, carinho e respeito.

À Milena Fernandes da Rocha, pelo verdadeiro suporte e por ter me suportado em momentos tão sensíveis, pela fiel cumplicidade e permanência que supera limites. 


\section{RESUMO}

Este trabalho tem como escopo a investigação: das relações estabelecidas entre a dupla oposição nome/verbo e argumento/predicado; da funcionalidade do sufixo $-a$ em línguas da família linguística Tupí-Guaraní (FLTG); e do papel central do parâmetro omnipredicativo na FLTG. O corpus compõe-se de textos produzidos no cenário de estudos em línguas indígenas - mais especificamente, das línguas Tupinambá, Tapirapé, Guajá e Kamaiurá documentando aspectos sócio-históricos e linguísticos de comunidades presentes no território brasileiro. A pesquisa baseia-se nos pressupostos do Funcionalismo, sobretudo nos trabalhos de Givón (1995, 2001), Comrie (1981), Hopper \& Thompson (1984) e DeLancey (2000). Esta pesquisa pressupõe a descrição das línguas, principalmente, como um instrumento de interação social, cujo sistema linguístico está subordinado ao uso da língua; portanto uma maior ocorrência do sufixo - $a$ em uma língua e seu apagamento em outra estão ligados, também, aos efeitos de evolução gramatical sofridos diacronicamente nas interações dos falantes. Busco, entre os resultados, contribuir para as reflexões teóricas empreendidas em torno dos processos morfossintáticos de línguas da FLTG, identificando os possíveis ambientes de ocorrência do sufixo -a e o motivo das variadas terminologias engendradas para se referir a esse sufixo.

Palavras-chave: Funcionalismo. Línguas indígenas. Família Linguística Tupí-Guaraní. Omnipredicatividade. Sufixo -a. 


\begin{abstract}
This work is the result of a research that aims to investigate: the relation established between the dual opposition name/verb and argument/predicate; the functionality of the suffix -a in languages of the Tupí-Guaraní linguistic family (TGLF); and the central role of omnipredicative parameter in TGLF. The corpus consists of texts produced in the scenario of studies about indigenous languages - more specifically, Tupinambá, Tapirapé, Guajá and Kamaiurá - documenting socio-historical and linguistic aspects of some communities in Brazil. The research is based on the assumptions of Functionalism, mainly in the works of Givón (1995, 2001), Comrie (1981), Hopper \& Thompson (1984) and DeLancey (2000). This research presupposes the description of languages mainly as a tool for social interaction, which have a linguistic system subordinated to the use of language; therefore, a greater occurrence of the suffix -a in one language and their deletion in other are also connected to the effects of the diachronic development of grammar in the interactions of speakers. As results, I intend to contribute to the theoretical reflections undertaken around the morphosyntactic processes in languages of TGLF, identifying the possibilities of occurrence of suffix -a and the reason of the varied terminology engineered to refer to this suffix.
\end{abstract}

Keywords: Functionalism. Indigenous languages. Tupí-Guaraní linguistic family. Omnipredicativity. Suffix -a. 


\section{LISTA DE TABELAS}

Tabela 1. Escala de estabilidade temporal de Givón (2001, p. 54) ........................................ 20

Tabela 2. Marcadores de pessoa das séries I e II do Tapirapé (PRAÇA, 2007, p. 96)........... 22

Tabela 3. Tipos semânticos para os adjetivos, propostos por Dixon, aplicados aos adjetivos no Guajá (DIXON, 1977 apud MAGALHÃES, 2007, p. 20)

Tabela 4. Tipos semânticos para os adjetivos, propostos por Dixon, aplicados aos verbos descritivos do Kamaiurá (DIXON, 1977 apud SEKI, 2000, p. 67) .........................................36

Tabela 5. Funções para nomes e verbos do Tapirapé quando marcados com $-a$..................... 70

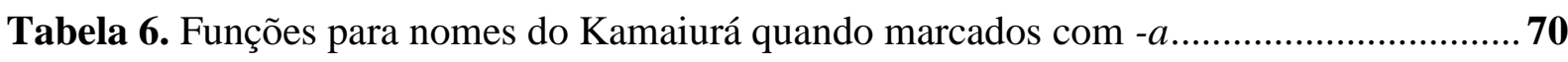

Tabela 7. Funções para nomes do Guajá quando marcados com $-a$..................................... 71 


\section{LISTA DE FIGURAS}

Figura 1. Localização aproximada das línguas da família linguística Tupí-Guaraní .............. 11 


\section{ABREVIATURAS E SÍMBOLOS UTILIZADOS}

\section{Tapirapé}

$\begin{array}{ll}\text { I } & \text { alternância } \\ \text { II } & \text { Serie I } \\ \text { III } & \text { Serie II } \\ \text { R } & \text { Serie III } \\ \text { 1sg } & \text { relacional } \\ \text { 1excl } & \text { primeira pessoa do singular } \\ \text { 1incl } & \text { primeira pessoa do plural exclusiva } \\ \text { 2sg } & \text { primeira pessoa do plural inclusiva } \\ \text { 2pl } & \text { segunda pessoa do singular } \\ 3 & \text { segunda pessoa do plural } \\ \text { ATE } & \text { terceira pessoa } \\ \text { CAUS } & \text { atenuativo } \\ \text { DEM } & \text { causativo } \\ \text { FN } & \text { demonstrativo } \\ \text { GER } & \text { futuro nominal } \\ \text { HAB } & \text { gerúndio } \\ \text { I2 } & \text { aspecto habitual } \\ \text { IMP } & \text { indicativo 2 } \\ \text { INT } & \text { imperativo } \\ \text { LOC } & \text { locativo } \\ \text { N.PROC } & \text { nominalização de instrumento, processo, local } \\ \text { PAS.MED } & \text { passado médio } \\ \text { PAS.REC } & \text { passado recente } \\ \text { PN } & \text { passado nominal } \\ \text { POS } & \text { posposição } \\ \text { REDUP } & \text { reduplicação } \\ \text { REF } & \text { reflexivo } \\ \text { REFER } & \text { referenciante } \\ \text { SG } & \text { singular } \\ \text { SI } & \text { similaridade } \\ \text { VEL } & \text { velho } \\ & \end{array}$

\section{Guajá}

\begin{tabular}{|c|c|}
\hline ATEN & sufixo de atenuação \\
\hline CAUS & morfema causativo \\
\hline CAUS.COM & prefixo causativo-comitativo \\
\hline $\mathrm{COL}$ & sufixo coletivizador \\
\hline COMPL & partícula de aspecto completivo \\
\hline COND & partícula de modalidade deôntica 'seria bom se' \\
\hline CONS & subordinador de consecutividade \\
\hline CTF & partícula direcional centrífuga \\
\hline DEM & demonstrativo \\
\hline FOC & partícula de foco contrastivo \\
\hline
\end{tabular}




$\begin{array}{ll}\text { FREQ } & \text { advérbio que exprime frequência } \\ \text { GER } & \text { subordinador do modo gerúndio } \\ \text { INT } & \text { partícula interrogativa I } \\ \text { INTS } & \text { sufixo de intensidade } \\ \text { INSTR } & \text { posposição instrumental } \\ \text { LOC } & \text { sufixo de caso locativo } \\ \text { MED } & \text { partícula evidencial mediativa } \\ \text { MOSTR } & \text { partícula mostrativa } \\ \text { N } & \text { sufixo nominal } \\ \text { NEG } & \text { negação } \\ \text { NZR } & \text { afixo nominalizador } \\ \text { PERF } & \text { partícula de aspecto perfectivo } \\ \text { PERFT } & \text { partícula de aspecto perfeito } \\ \text { PLU } & \text { partícula pluralizadora de sujeito } \\ \text { POS1 } & \text { partícula posicional 'em movimento' } \\ \text { POSS } & \text { partícula epistêmica de possibilidade } \\ \text { PROIB } & \text { partícula proibitiva } \\ \text { PROJ } & \text { partícula de aspecto projetivo } \\ \text { R1 } & \text { prefixo relacional de referente contíguo } \\ \text { R } & \text { prefixo relacional de referente não-contíguo } \\ \text { REAL } & \text { particular epistêmica de pressuposição } \\ \text { RED } & \text { reduplicação } \\ \text { RETR } & \text { sufixo de atualização nominal retrospectiva } \\ \text { SEME } & \text { sufixo derivative de semelhança } \\ \text { SIMIL } & \text { partícula epistêmica similativa } \\ \text { TRANS } & \text { sufixo de caso translativo } \\ 1 & \text { primeira pessoa singular, 'eu, me' } \\ 12 & \text { primeira pessoa plural inclusiva, 'nós, nos' } \\ 13 & \text { primeira pessoa plural exclusiva, 'nós, nos' } \\ 2 & \text { segunda pessoa singular, 'tu, te' } \\ 23 & \text { segunda pessoa plural, 'vós, vos' } \\ 3 & \text { terceira pessoa, 'ele (a), eles (as)' } \\ 33 & \text { terceira pessoa plural 'eles (as)' } \\ \infty & \text { alternância gramaticalmente ou lexicalmente condicionada } \\ \sim & \text { alternância fonologicamente condicionada } \\ * & \text { agramatical } \\ & \end{array}$

\section{Kamaiurá}

A Sujeito de verbo transitivo

Abl Ablativo

Al Alativo

Aten Atenuativo

Atr Caso Atributivo

Atual Atual

Caus Causativo

Circ Modo circunstancial

Col Coletivo

Comp Comparativo

Compl Completivo 


$\begin{array}{ll}\text { Conc } & \text { Concessivo } \\ \text { Cons } & \text { Consecutivo } \\ \text { Cont } & \text { Continuativo } \\ \text { Cóp } & \text { Cópula } \\ \text { Dem } & \text { Demonstrativo } \\ \text { Excl } & \text { Exclusivo } \\ \text { F } & \text { Foco } \\ \text { FS } & \text { Fim de sentença } \\ \text { Fut } & \text { Futuro } \\ \text { G } & \text { Modo Gerúndio } \\ \text { Hab } & \text { Habitual } \\ \text { Imper } & \text { Imperativo } \\ \text { Instr } & \text { Instrumental } \\ \text { Intens } & \text { Intensivo } \\ \text { Loc } & \text { Caso Locativo } \\ \text { MS } & \text { Falante do sexo masculino } \\ \text { N } & \text { Caso Nuclear } \\ \text { Neg } & \text { Negativo } \\ \text { Nom } & \text { Nominalizador } \\ \text { O } & \text { Objeto direto } \\ \text { Oi } & \text { Objeto indireto } \\ \text { Opin } & \text { Opinativo } \\ \text { Pas } & \text { Passado } \\ \text { Pe } & \text { Pessoa exclusiva } \\ \text { Perf } & \text { Perfectivo } \\ \text { Perm } & \text { Permissivo } \\ \text { Pi } & \text { Pessoa inclusiva } \\ \text { Pl } & \text { Plural } \\ \text { Posp } & \text { Posposição } \\ \text { Pos } & \text { Possessivo } \\ \text { Proib } & \text { Proibitivo } \\ \text { Próx } & \text { Próximo } \\ \text { Q } & \text { Interrogativo } \\ \text { Rec } & \text { Recíproco } \\ \text { Refl } & \text { Reflexivo } \\ \text { Rel } & \text { Prefixo Relacional } \\ \text { S } & \text { Sujeito de V. Intransitivo } \\ \text { Sa } & \text { Sujeito de V. Intransitivo Ativo } \\ \text { Sg } & \text { Singular } \\ \text { So } & \text { Sujeito de V. Descritivo } \\ \text { Subj } & \text { Modo Subjuntivo } \\ \text { V } & \text { Verbo } \\ \text { Vi } & \text { Verbo intransitivo } \\ \text { Voc } & \text { Vocativo } \\ \text { I } & \text { informação contextual } \\ & \end{array}$




\section{Tupinambá}

$\begin{array}{ll}\text { ARG } & \text { sufixo do caso argumentativo } \\ \text { CIRC } & \text { sufixo do modo circunstancial } \\ \text { CONT } & \text { prefixo indicador de determinante contíguo } \\ \text { GER } & \text { sufixo do gerúndio (pred. de oração com o mesmo sujeito que a principal) } \\ \text { HUM } & \text { prefixo indicador de determinante humano } \\ \text { INT } & \text { partícula interrogativa } \\ \text { LOCDF } & \text { sufixo do caso locativo difuso } \\ \text { LOCPT } & \text { sufixo do caso locativo pontual } \\ \text { NCONT } & \text { prefixo indicador de determinante não-contíguo } \\ \text { NEG } & \text { sufixo marcador de negação } \\ \text { OBJ } & \text { prefixo marcador de objeto direto } \\ \text { SUBJ } & \text { sufixo do modo subjuntivo } \\ \text { SUJ } & \text { prefixo marcador de sujeito } \\ \text { TRANSL } & \text { sufixo do caso translativo (também chamado caso predicativo) }\end{array}$


RESUMO

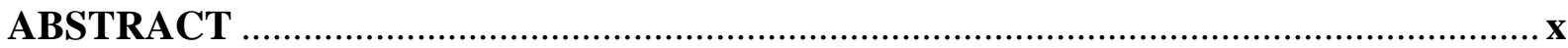

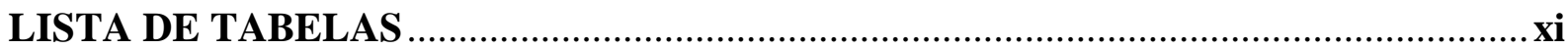

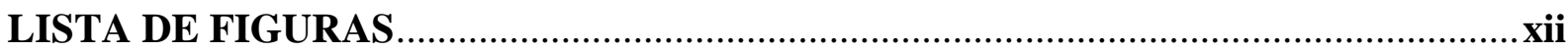

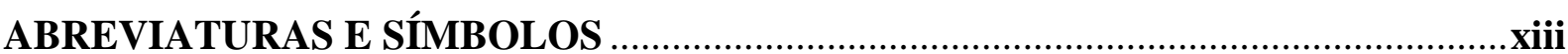

0 - INTRODUÇÃO

0.1 Justificativa

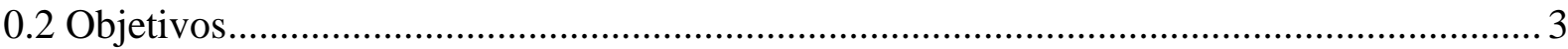

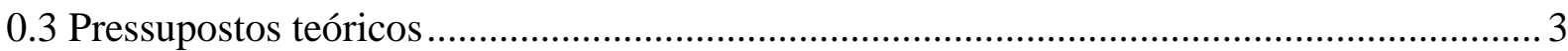

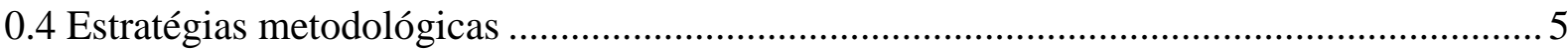

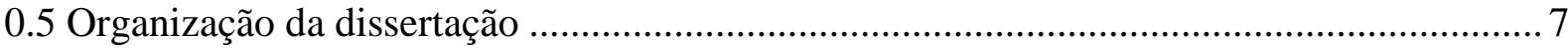

CAPÍTULO 1 - A FAMÍLIA LINGUÍSTICA TUPÍ-GUARANÍ .................................... 8

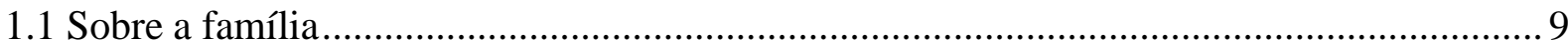

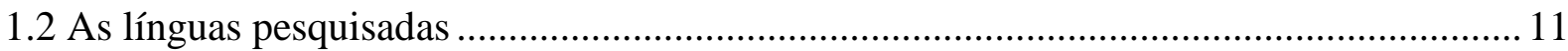

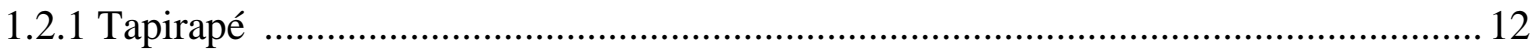

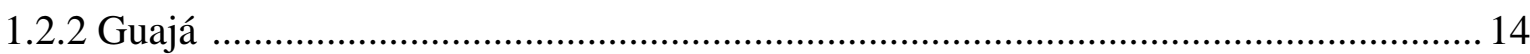

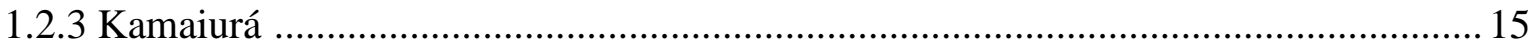

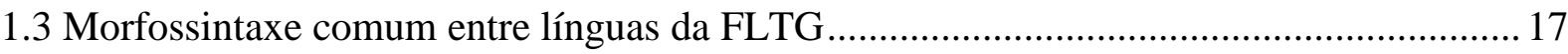

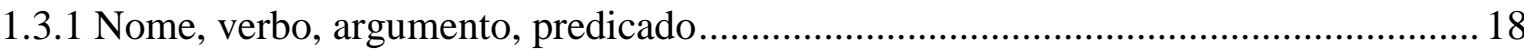

CAPÍTULO 2 - AS CLASSES LEXICAIS NOME E VERBO …............................... 19

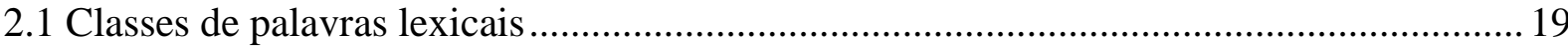

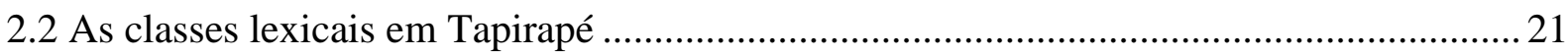

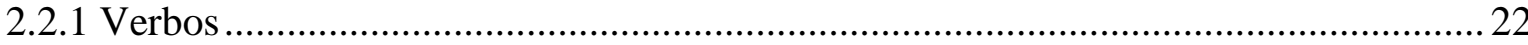

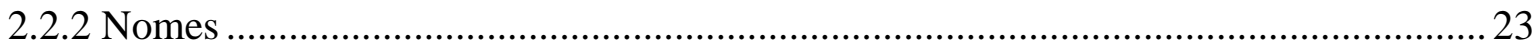

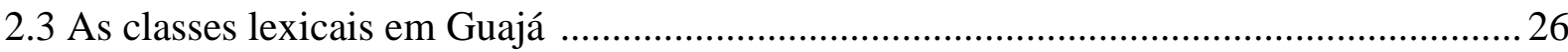

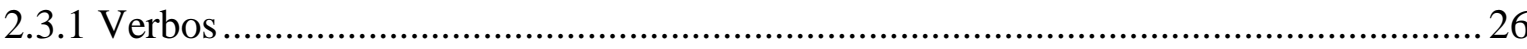

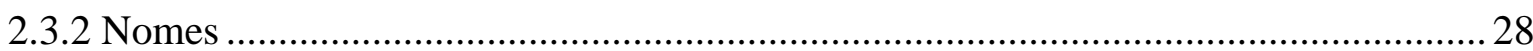

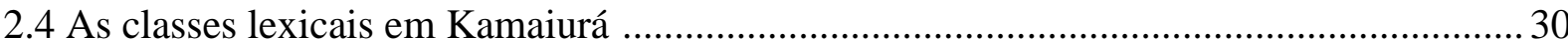

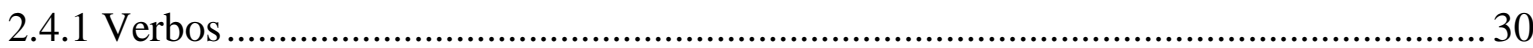

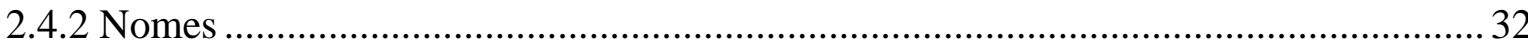

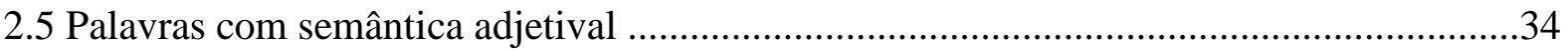

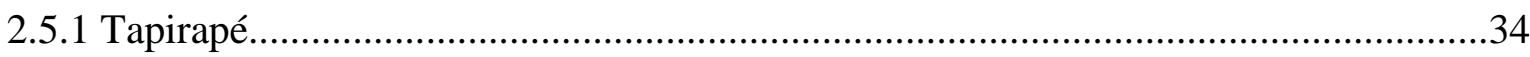

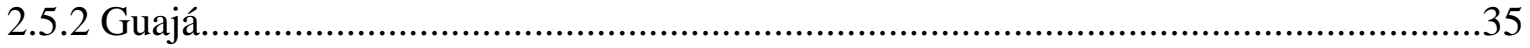

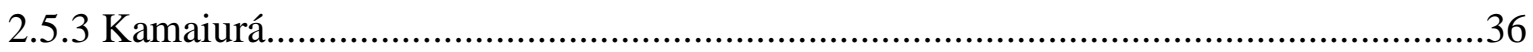

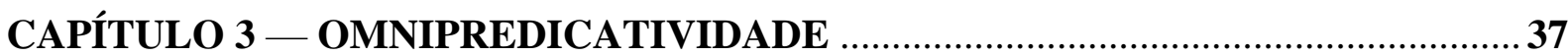

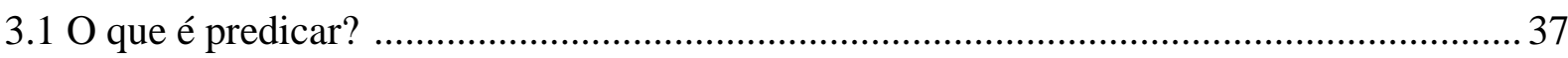




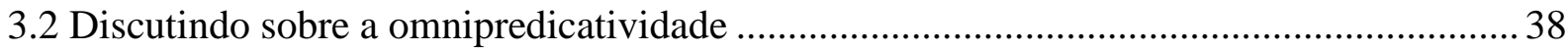

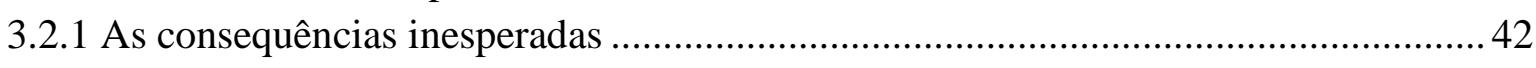

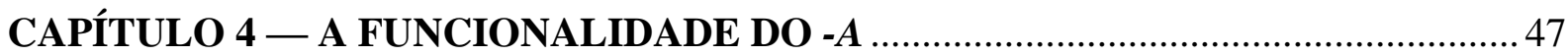

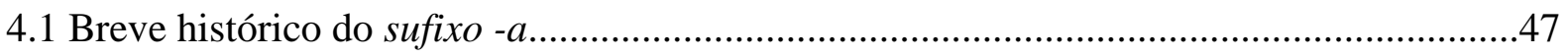

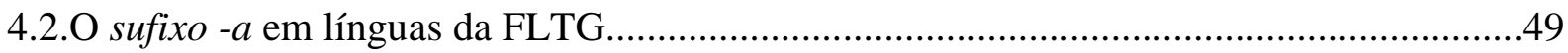

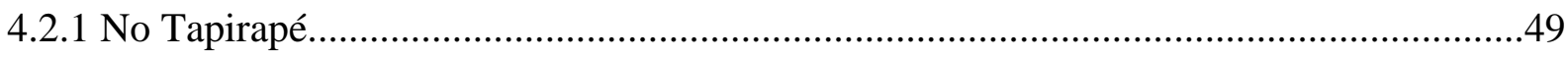

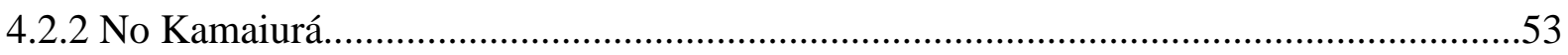

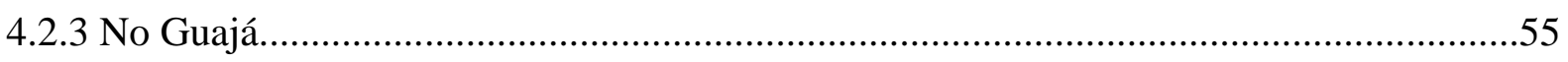

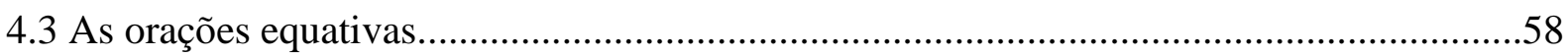

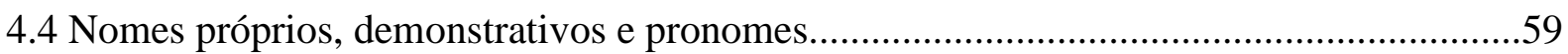

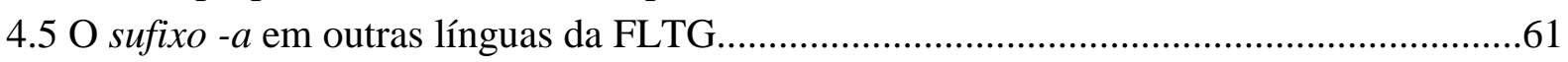

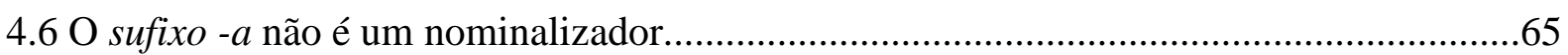

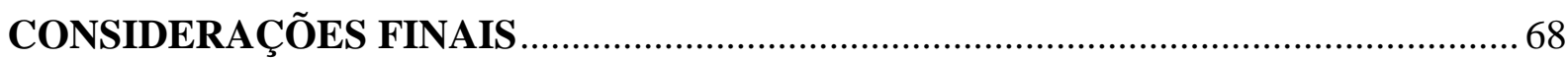

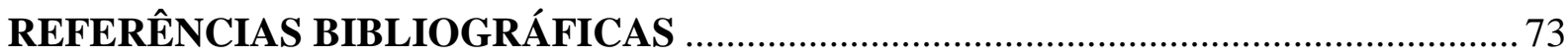




\section{$\mathbf{0}$}

\section{INTRODUÇÃO}

“A distinção verbo-nome não é nítida, pois todo nome pode tornar-se predicativo, e todo verbo no infinitivo é um verdadeiro nome. Os mesmos morfemas parece terem dois 'status': o verbal e o nominal" (BARBOSA, 1956, p. 393).

Uma das propriedades morfossintáticas mais interessantes da família linguística Tupí-Guaraní implica uma relativa independência entre as classes lexicais nome e verbo e os constituintes sintáticos argumento e predicado. Barbosa (1956, p. 393) já afirmava a possibilidade de os mesmos morfemas terem dois status, o verbal e o nominal, porém, na época, não houve grandes estudos sobre esse fenômeno. Há alguns anos, pesquisadores de línguas Tupí-Guaraní,após perceberem que o critério sintático (conforme o qual a função básica do nome é a de ser argumento e a do verbo é a de ser predicado) é irrelevante para distingui-los como duas classes lexicais distintas, motivaram colocações quanto à não existência, nessas línguas, de uma distinção clara entre o nome e o verbo.

Quanto à distinção entre nomes e verbos, nos estudos mais recentes acerca dessas línguas - no Tupi (RODRIGUES, 1953), no Tupinambá (RODRIGUES, 1981; 1996; 2001), no Tapirapé (PRAÇA, 1999; 2006; 2007), no Kamaiurá (SEKI, 1990; 2000; 2001), no Emerillon (ROSE, 2003), no Awá Guajá (MAGALHÃES, 2007), entre outras —, percebemse critérios morfológicos bem delimitados e específicos em cada uma das línguas, no entanto ainda é curioso que tanto nomes quanto verbos possam exercer as funções sintáticas de predicado ou de argumento, sendo a função tipicamente nominal assinalada pelo sufixo - $a$, além de compartilharem outras similaridades morfossintáticas.

Em geral, os linguistas dispõem de quatro níveis de análise linguística para definir as principais classes de palavras de uma língua: o semântico, o morfológico, o sintático e o pragmático. A complexidade da identificação de nomes e verbos nas línguas demonstra que os critérios utilizados para o estabelecimento dessas classes lexicais não são universais; antes, são específicos de cada língua.

Analisando morfossintaticamente nomes e verbos em línguas da família linguística Tupí-Guaraní (doravante FLTG), percebe-se comportamento especialmente interessante na identificação das classes para a função predicativa, tornando-se, inclusive, 
discussão central deste trabalho. Presume-se que as línguas da família seriam descendentes de uma língua em que todas as entradas lexicais tinham como vocação primária a função predicativa (QUEIXALÓS, 2001a, 2001b). Outras línguas atuais e independentes geneticamente foram descritas anteriormente como apresentando esse padrão morfossintático, para o qual Launey cunhou o termo onipredicatividade (LAUNEY, 1986). Para Queixalós (2001), o grau de omnipredicatividade em línguas da FLTG é variável e estaria relacionado a produtividade do sufixo - $a$, discussão que será aprofundada no Capítulo 3.

\subsection{Justificativa}

Sob o ponto de vista social, este estudo pretende reconhecer o valor das especificidades indígenas culturais e, sobretudo, linguísticas. Pretende, também, contribuir com os demais trabalhos documentais já existentes dessas línguas estudadas, principalmente na medida em que os resultados poderão subsidiar ações relacionadas à manutenção da língua e dos valores culturais que elas traduzem e aos programas de educação bilíngue dos ensinos fundamental e médio, já implantados em algumas das comunidades indígenas falantes de línguas Tupí-Guraní.

Sob a perspectiva de sua relevância científico-acadêmica, apesar de os estudos mais recentes esclarecerem, a partir de critérios específicos a cada língua, a diferença morfológica e lexical entre nomes e verbos, o sufixo - $a$ ainda apresenta funções diferentes no plano sintático das línguas. Comum a muitas línguas da FLTG e sendo, normalmente, analisado pelos especialistas de maneira bastante homogênea, tem sido descrito na literatura linguística com denominações variadas, a saber: nominalizante (BARBOSA, 1956); índice nominal (RODRIGUES, 1953; BARBOSA, 1956); caso argumentativo, ou nominal, ou nominativo (RODRIGUES, 1996; 2001; PRAÇA, 1999; MAGALHÃES, 2007), nominal function marker (SEKI, 1990; 2001), caso nuclear (SEKI, 2000), referenciante (QUEIXALÓS, 2006; PRAÇA, 2007), entre outras.

Evidenciando uma forte demanda de pesquisas relacionadas à investigação do sufixo - $a$ e sua função nas línguas da FLTG, este estudo pretende contribuir para as reflexões teóricas empreendidas em torno dos processos morfossintáticos das línguas Tupí-Guaraní e para a harmonização da terminologia engendrada para se referir ao sufixo - $a$. 


\subsection{Objetivos}

Este estudo tem como objetivo principal investigar a ocorrência do sufixo -a em línguas da família linguística Tupí-Guaraní, descrevendo sua funcionalidade e propondo uma reflexão acerca da omnipredicatividade.

Em diálogo com o objetivo principal, são objetivos específicos:

(i) descrever os critérios até então elencados para definir as classes de nomes e verbos em línguas da FLTG;

(ii) propor uma reflexão acerca da omnipredicatividade, apresentando as caraterísticas elencadas por Launey (2004);

(iii) descrever as possibilidades de ocorrência do sufixo - $a$ nas línguas em estudo;

(iv) descrever a estrutura de predicados nominais com e sem a marcação do sufixo - $a$.

\subsection{Pressupostos teóricos}

Partindo do pressuposto de que a linguagem é um instrumento de comunicação, esta pesquisa segue uma abordagem funcionalista, já que nela desenvolve-se um tratamento funcional da própria organização interna da linguagem, isto é, os participantes do enunciado, o momento da enunciação e os demais componentes que formam o contexto enunciativo são fundamentais para a análise das estruturas gramaticais. Como afirma Cunha (2003, p. 29), "segundo a hipótese funcionalista, a estrutura gramatical depende do uso que se faz da língua, ou seja, a estrutura é movida pela situação comunicativa”.

Apesar de haver diversas perspectivas de estudos funcionalistas e todos admitirem o postulado da não autonomia da língua, a gramática não podendo ser entendida de forma isolada, faz-se necessário delimitar a abordagem utilizada nesta pesquisa. Tomando, então, como fundamentação teórica o funcionalismo, trabalhos desenvolvidos por Givón (1995; 2001), Comrie (1981), Hopper \& Thompson (1984), DeLancey (2000) e outros dão suporte teórico para esta pesquisa. A partir dessa abordagem, a gramática de uma língua é vista como um conjunto de regularidades decorrentes de pressões cognitivas e do uso, ou seja, um sistema aberto, fortemente suscetível às mudanças e intensamente afetado pelo emprego que lhe é dado nos momentos de interação, sofrendo influência inclusive da frequência de uso. Como diz Hopper (1987, 1998), a gramática é emergente, variável, nunca está completa.

Para uma descrição que diz respeito à ocorrência do sufixo -a em línguas da família linguística Tupí-Guaraní, faz-se necessário apontar a definição escolhida para esta 
pesquisa em relação aos processos morfológicos. A partir disto, destaca-se a distinção feita por Payne (2006), de base funcionalista, em que o autor elenca parâmetros que caracterizam os fenômenos da morfologia flexional e da morfologia derivacional.

A morfologia flexional se caracteriza por: (i) raramente ocasionar mudança de classes de palavras; (ii) ter forte motivação pelo ambiente sintático, ou seja, corresponder a um processo morfológico quase compulsório, relacionado aos fenômenos de concordância verbal e nominal, por exemplo; (iii) não alterar o significado lexical básico de uma raiz; (iv) possuir paradigmas bem definidos e produtivos quanto à sua ocorrência, potencialmente usados em todas as raízes de uma classe ou subclasse, ocasionando o mesmo efeito cada vez que são aplicados.

Já a morfologia derivacional se caracteriza por: (i) muitas vezes, ocasionar a mudança de classes de palavras; (ii) não possuir um caráter obrigatório no texto, ou seja, não ser fruto obrigatório do ambiente sintático, atendendo, na verdade, às necessidades e intenções do falante; (iii) alterar o significado da raiz; (iv) relativamente, não possuir paradigmas produtivos quanto à aplicação a todas as raízes de uma classe, não tendo esses paradigmas, necessariamente, o mesmo efeito quando aplicados, relacionando-se de forma idiossincrática com outras categorias derivacionais (PAYNE, 2006, p. 39).

Para descrever as classes de palavras das línguas Tupí-Guaraní, convoca-se a proposta de análise de Givón (2001), que apresentou uma descrição das classes lexicais (classes de palavras) na qual está implícito um tratamento semântico lexical. O autor dividiu o vocabulário das línguas em dois tipos gerais: palavras lexicais (de conteúdo) - codificam conceitos estáveis e compartilhados culturalmente ou tipos de experiências - e palavras não lexicais (de função) - codificam funções gramaticais e são representadas por muitas e pequenas classes relativamente fechadas.

Segundo o autor, há quatro classes principais de palavras lexicais nas línguas: nomes, verbos, adjetivos e advérbios, sendo esta última mista em termos tanto de critérios semânticos quanto de critérios morfológicos e sintáticos. Para distinguir os membros de cada uma das classes lexicais, devem ser elencados três critérios: o semântico (que tipo de significado tende a ser codificado por cada classe particular), o morfológico (que tipo de morfemas gramaticais e derivacionais tende a ser afixado numa classe particular) e o sintático (que posições típicas na sentença as palavras de uma classe particular tendem a ocupar) (GIVÓN, 2001). 
Givón (2001) propõe a separação das classes dos nomes, adjetivos e verbos por meio de um conjunto de quatro critérios semânticos estreitamente associados: estabilidade temporal, complexidade, concretude e compacidade espacial. Para os fins desta pesquisa, merecem relevo, por ora, apenas as classes de nomes e verbos. De acordo com o linguista, os nomes, com base em suas características semânticas prototípicas, revelam-se como entidade, tendo configuração espacial e estabilidade corporal; os verbos, com base em suas características semânticas prototípicas, revelam-se como tendo instabilidade temporal e não inscrição no espaço.

Partindo-se da afirmação de Barbosa (1956, p. 393) acerca das línguas TupíGuaraní - “A distinção verbo-nome não é nítida, pois todo nome pode tornar-se predicativo, e todo verbo no infinitivo é um verdadeiro nome. Os mesmos morfemas parece terem dois 'status': o verbal e o nominal" —, torna-se necessário trabalhar com o que Praça (2007) chamou de morfologia transcategorial. Essa morfologia se responsabiliza por analisar e descrever recursos linguísticos presentes em diferentes tipos de constituintes, principalmente nos compostos de nomes e verbos, quando esses sufixos não se mostram exclusivos de uma só classe, comportamento observado com o sufixo $-a$.

Uma das justificativas para essa morfologia transcategorial na FLTG seria o comportamento omnipredicativo, proposto inicialmente por Launey (1986) e, posteriormente, fortalecido nos estudos dos especialistas das línguas Tupí-Guaraní. Esse possível motivo pelo qual é central, em Tupí-Guaraní, a natureza não criterial da função predicativa na identificação das classes é a presunção de que as línguas da família seriam descendentes de uma língua em que todas as entradas lexicais tinham como vocação primária a função predicativa (QUEIXALÓS, 2006).

\subsection{Estratégias metodológicas}

Este estudo baseia-se em um referencial teórico funcional delineado em trabalhos de Seki (1990; 2000; 2001), Praça (1998; 2007), Queixalós (2001; 2006), Magalhães (2007), Cruz (2011) e outros. Utiliza como procedimento técnico a pesquisa bibliográfica, que, segundo Lakatos e Marconi (1991, p. 58), “é um apanhado geral sobre os principais trabalhos já realizados, revestidos de importância, por serem capazes de fornecer dados atuais e relevantes relacionados com o tema". O desenvolvimento da pesquisa baseouse na revisão, na análise e no estudo de publicações primárias e secundárias das línguas 
Tapirapé, Awá Guajá e Kamaiurá: gramáticas, teses, dissertações, artigos e publicações de gêneros diversos acerca da gramática e fonologia dessas línguas.

A partir dessa concepção, a escolha das línguas considerou os seguintes critérios: (i) línguas pertencentes à FLTG; (ii) línguas pertencentes a subconjuntos diferentes; (iii) línguas que disponibilizassem quantidade de material suficiente para análise; (iv) línguas de cuja história linguística o sufixo - a fizesse parte e (v) línguas que apresentassem aspectos diferentes sobre a função do sufixo - $a$. Assim, foram escolhidas as línguas: Tapirapé, Awá Guajá e Kamaiurá.

Para a análise dos dados, alguns dos trabalhos centrais são: (i) as gramáticas $A$ língua Tapirapé (ALMEIDA; IRMÃNZINHAS DE JESUS \& PAULA, 1983) e a Gramática do Kamaiurá (SEKI, 2000); (ii) as teses Sobre a morfologia e a sintaxe da língua Guajá (MAGALHÃES, 2007) e Morfossintaxe da língua Tapirapé (PRAÇA, 2007); (iii) a dissertação A cisão intransitiva em línguas da família Tupí-Guaraní (MATTOS, 2015); e (iv) os trabalhos Sobre a Natureza do Caso Argumentativo (RODRIGUES, 2001), Classes de palavras e categorias sintático-funcionais em Kamaiurá (SEKI, 2001) e A dupla oposição nomelverbo e argumento/predicado em Tapirapé (PRAÇA, 2006). Este corpus foi considerado coerente com os fins desta pesquisa, uma vez que os trabalhos citados foram desenvolvidos por especialistas nas línguas Tupí-Guaraní, reconhecidos no cenário de estudos de línguas indígenas e, de acordo com os autores, os dados disponibilizados por esses trabalhos foram gerados, em sua maioria, em situações reais e espontâneas de fala das comunidades indígenas, documentando a língua em uso.

A análise dos dados seguiu base qualitativa, que, de acordo com Russell (1940 apud MAGALHÃES, 2007, p. 7), pode ser definida como a procura de padrões e de ideias que ajudam a explicar a existência desses padrões, pois, "na medida em que você desenvolve ideias, vai tentando-as com os seus dados; seus dados devem então modificar suas ideias que devem, então, ser testadas novamente e assim por diante".

O termo sufixo - $a$ foi escolhido como a expressão mais genérica para se referir ao que os especialistas da família linguística Tupí-Guaraní, ao se depararem com ele em quase todas as línguas, denominaram de diversas formas. Por fim, é necessário esclarecer que os exemplos citados nesta pesquisa foram apresentados obedecendo as glosas e a disposição utilizada por cada um dos linguistas especialistas dessas línguas, que serão devidamente citados. Para este trabalho foram feitas duas alterações nos exemplos: foram renumerados, para uma apresentação linear condizente com os propósitos da pesquisa e, além disso, 
considerando as várias referências feitas ao morfema, no decorrer do trabalho, em todos os exemplos citados, o sufixo - a será glosado como X para manter a uniformidade, padronizar a referência ao sufixo e economizar em abreviaturas e símbolos.

\subsection{Organização da dissertação}

O Capítulo 1 apresenta como os crimes de genocídio e etnocídio contra as comunidades indígenas se desdobraram na história do Brasil e ainda permanecem, mesmo que de forma mais silenciosa. Apresenta também as informações histórico-geográficas sobre a FLTG e as principais bibliografias consultadas sobre as línguas que embasaram esta pesquisa.

O Capítulo 2, em um nível de análise lexical, fundamenta, a partir da abordagem funcionalista de Givón (2001), a noção de classes lexicais. Descreve os critérios específicos propostos pelos especialistas para as classes de nomes e verbos na FLTG, bem como a existência, ou não, de uma classe de adjetivos.

O Capítulo 3 apresenta o parâmetro da omnipredicatividade, proposto por Launey (1986), conforme o qual todas as entradas lexicais de determinada língua têm como vocação primária a predicação.

O Capítulo 4 exibe as análises empreendidas por cada pesquisador para a ocorrência do sufixo - $a$ nas línguas que estudam: Praça (2007) o descreve como sendo referenciante; Magalhães (2007) o descreve como sendo caso nominativo; e Seki (2000, 2001) o descreve como sendo caso nuclear. Nesse capítulo também serão destacados alguns aspectos específicos que diferenciam a funcionalidade do sufixo em cada uma dessas línguas.

Por fim, na Conclusão, estão as considerações finais decorrentes da pesquisa, implicações que possibilitam maiores investigações e contribuições deste trabalho para as comunidades indígenas e a comunidade acadêmica, apontando para a necessidade de avanço nessas investigações. 


\title{
A FAMília LINGUÍSTICA TUPÍ-GUARANí
}

\begin{abstract}
Atualmente, em toda a América do Sul, os últimos índios livres sucumbem sob a pressão enorme do crescimento econômico, brasileiro em particular. As estradas transcontinentais, cuja construção se acelera, constituem eixos de colonização dos territórios atravessados: azar dos índios com quem a estrada depara! Que importância podem ter alguns milhares de selvagens improdutivos comparada à riqueza em ouro, minérios raros, petróleo, em criação de bovinos, em plantações de café etc.? Produzir ou morrer, é a divisa do Ocidente (CLASTRES, 2004, p. 62-63).
\end{abstract}

As pesquisas científicas em línguas indígenas no Brasil revelam que, desde a chegada dos europeus ao Brasil, elas, as línguas, têm estado continuamente submetidas a um processo de extinção (ou mesmo de exterminação) ${ }^{1}$ de espécies com consequências extremamente graves. Hoje, há, aproximadamente, 240 povos indígenas, dos quais 180 falam línguas indígenas no país e, os demais, falam uma variedade do português, mas essas línguas são apenas $15 \%$ das mais de mil línguas que se calcula terem existido aqui em 1500 (RODRIGUES, 1993a; 1993b), considerando-se, por exemplo, que quase todas as línguas indígenas que se falavam nas regiões nordeste, sudeste e sul do Brasil desapareceram.

Tendo em vista não só a superfície de contato, como também a sobreposição que há entre língua e cultura, essa extinção drástica de línguas pressupõe, reflete e implica, necessariamente, o aniquilamento de culturas milenares e de tudo o que elas representam e constroem em termos de sabedoria, diversidade e pluriculturalidade. Desapareceram, também, as comunidades que faziam uso dessas línguas em suas interações cotidianas, traduzindo em uma enorme perda quantitativa uma perda qualitativa ainda maior. Culturas e línguas com propriedades desconhecidas desapareceram sem deixar vestígios, e provavelmente alguns povos e algumas famílias linguísticas inteiras deixaram de existir.

Pode-se refletir sobre esses desaparecimentos a partir dos conceitos de genocídio e etnocídio, amplamente explorados nas Ciências Sociais (CLASTRES, 2004). Tanto o genocídio quanto o etnocídio traduzem aversão ao outro e ao modus vivendi do outro,

\footnotetext{
${ }^{1}$ Proponho a distinção entre essas duas formas de minimização das culturas indígenas, extinção e exterminação, uma vez que a primeira está ligada ao desaparecimento de comunidades indígenas por questões mais indiretas com relação ao homem não indígena, ou menos motivadas/desejadas por ele. No entanto, a segunda forma, teria um caráter totalmente intencional, sendo, então, um crime de genocídio praticado por grupos de extermínio, tendo como objetivo principal acabar com todo e qualquer vestígio de presença indígena para inviabilizar a demarcação de terras, liberando-as para a apropriação privada, exploração dos recursos naturais, a pecuária e o agronegócio, por exemplo.
} 
pautada por relações étnicas assimétricas que visam à manutenção do poder. O crime de genocídio, com origem anterior aos massacres antissemitas cometidos em nome do nazismo, corresponde à destruição física dos seres humanos. A prática do etnocídio, por sua vez, equivale à alienação dos seres humanos de sua cultura materna, tornando-a invisível à medida que o indivíduo é imerso em outro contexto sociocultural, impondo-se-lhe novos paradigmas e parâmetros de valores e comportamentos ${ }^{2}$.

Por um lado, ao genocídio pode ser atribuído um caráter mais passional, visto que seu objetivo é extinguir a cultura a qualquer custo, inclusive por meio da exterminação de seus "portadores". O genocídio pode pautar-se, ainda, por motivações econômicas, compreendendo o indígena como um obstáculo ao progresso econômico. Por outro lado, o etnocídio possui uma natureza mais estratégica, que extingue a cultura sem exterminar seu portador, deixando-o vivo e livre para ser civilizado por outra cultura. Enquanto a perspectiva genocida não vê valor algum no indígena, a etnocida o enxerga como um diamante não lapidado, um terreno não explorado, uma potencial força de trabalho ou, ao menos, um potencial consumidor. Resumidamente, para Clastres (2004, p. 56), “o genocídio assassina os povos em seu corpo, o etnocídio os mata em seu espírito".

Tanto os crimes de genocídio quanto as práticas de etnocídio contra os indígenas no Brasil não se deram apenas durante o período colonial, mas mantiveram-se durante o período imperial e têm-se mantido no período republicano, às vezes, em certos momentos e em determinadas regiões com maior intensidade. Há grupos indígenas que sofreram uma grande depopulação e um quase aniquilamento social, mas que conseguiram se reerguer como uma comunidade que luta para se manter dentro de seus padrões culturais, preservando viva sua língua.

\subsection{Sobre a família}

A família linguística Tupí-Guaraní é um dos desdobramentos do tronco Tupi, composto de mais nove subdivisões ${ }^{3}$. Avalia-se a profundidade da família Tupí-Guaraní como de 1500 a 2500 e a do tronco Tupi de 4000 a 5000 anos (RODRIGUES, 1999). Apesar de a FLTG ser relativamente nova, a dispersão espacial dos seus povos foi muito mais ampla e rápida do que a das demais famílias do tronco Tupi.

\footnotetext{
2 Não se fala em "destruição da cultura", uma vez que não é conceitualmente concebível um ser humano "aculturado", ou seja, não há uma lacuna isenta de traços culturais entre a alienação da cultura materna e a aquisição de outra cultura.

${ }^{3}$ Famílias com um número pequeno de línguas (Arikém, Juruna, Mondé, Mundurukú Tupari e Ramarama), famílias que hoje consistem de só uma língua, como Aweti, Mawé (Sateré) e Puruborá (RODRIGUES, 1986).
} 
A FLTG possui cerca de trinta e cinco línguas fortemente relacionadas, o agrupamento das línguas em subgrupos foi proposto por Rodrigues (1984-1985), com base em homogeneidades fonológicas, morfológicas e lexicais entre as línguas. Dietrich (2010) propôs um agrupamento alternativo, levando em consideração critérios morfossintáticos. A FLTG apresenta uma distribuição geográfica bastante ampla na América do Sul. Seus extremos atuais são o litoral do Brasil (Leste), as margens do Amazonas na fronteira BrasilPeru (Oeste), sul da Guiana Francesa (Norte) e sul do Brasil, Paraguai e norte da Argentina (Sul). De acordo com Mello (2000), a distância entre esses extremos (Norte-Sul, Leste-Oeste) é de aproximadamente sete mil quilômetros.

A similaridade entre as línguas sugere uma expansão com grande rapidez, principalmente no sul e litoral do Brasil. Segundo Rodrigues (1996, p. 32), as línguas da FLTG estão:

(...) no Maranhão, Pará, Amapá, Amazonas, Mato Grosso e Mato Grosso do Sul, Goiás, São Paulo, Paraná, Santa Catarina, Rio Grande do Sul, Rio de Janeiro e Espírito Santo, assim como, fora do Brasil, na Guiana Francesa, na Venezuela, na Colômbia, no Peru, na Bolívia, no Paraguai e na Argentina.

A localização aproximada dos grupos indígenas Tupí-Guaraní é dada no mapa abaixo, proposto por Mello (2000). Agora extinta, a língua Tupinambá estava presente em três quartos da costa brasileira, da altura do Trópico de Capricórnio até o atual estado do Maranhão. Outras línguas extintas presentes no mapa são o Guarani antigo e o Apiaká. As línguas destacadas serão estudadas mais profundamente neste trabalho, são elas: o Tapirapé, o Guajá e o Kamaiurá. 


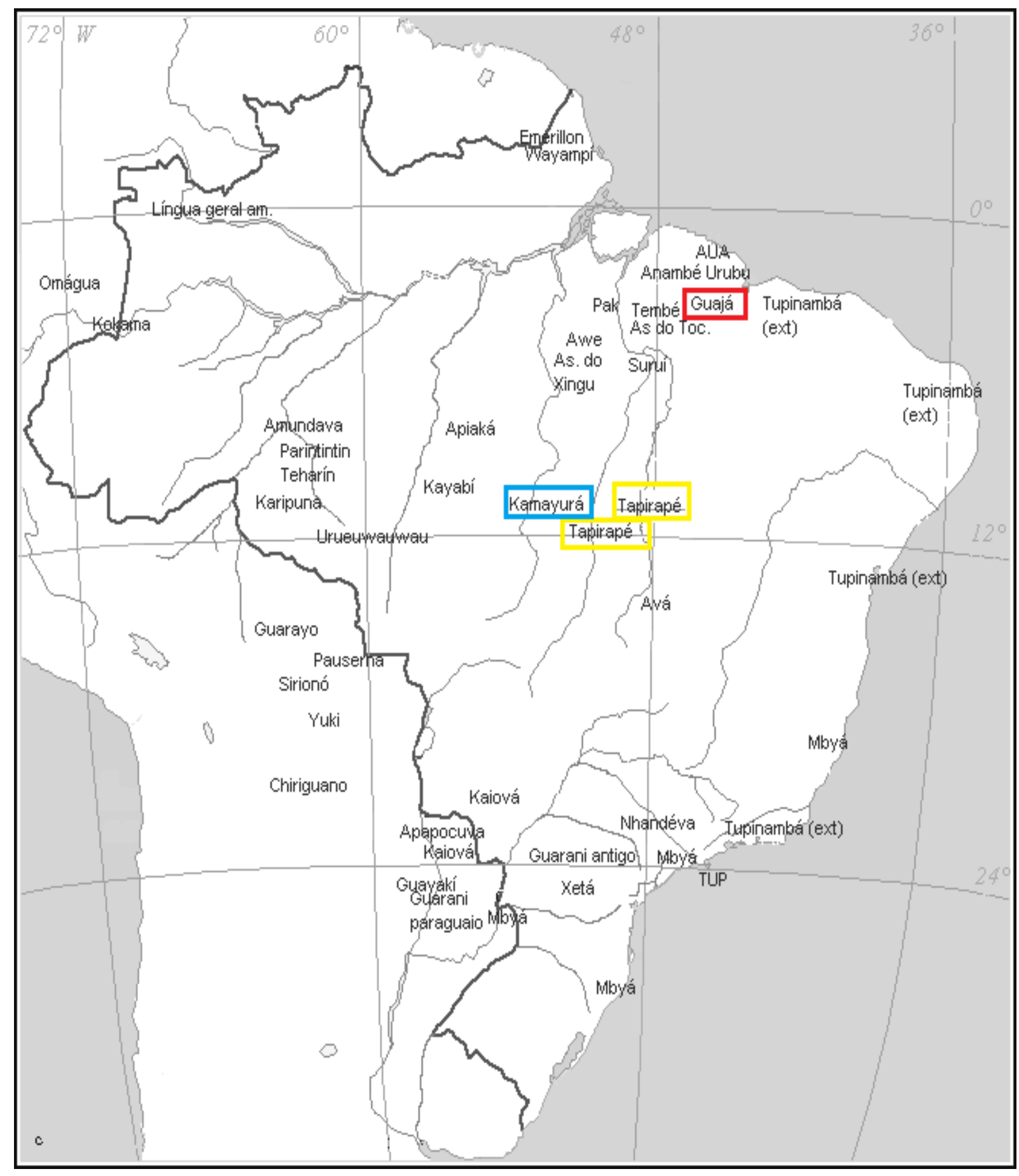

Figura 1. Localização aproximada das línguas da família linguística Tupí-Guaraní (MELLO, 2000, p. $13)$.

\subsection{As línguas pesquisadas}

A partir de trabalhos delineados por pesquisadores de línguas Tupí-Guaraní, percebem-se comunidades e línguas indígenas em situações diversas: alguns povos recémcontatados e com línguas, aparentemente, ainda pouco ameaçadas; povos que, apesar do 
contato de já alguns séculos, mantêm a língua bastante viva, como alguns povos Guarani; e povos que já não têm mais a língua indígena como língua materna ou língua de interações espontâneas.

Deve-se entender que todos os componentes de uma língua — seu sistema de sons, seu sistema morfológico e sintático e seu vocabulário, assim como suas estratégias de construção do discurso - mudam no decorrer do tempo e do espaço, em consequência de reajustes internos desses sistemas. Devido a mudanças na cultura e na organização social do povo que a fala e devido, também, às influências de outras línguas com as quais ela entra em contato em determinadas circunstâncias, os resultados dessas mudanças frequentemente coincidem com fenômenos já existentes em outras línguas, ou, às vezes, constituem inovações.

Essa constatação, acompanhada dos trabalhos desenvolvidos por especialistas da FLTG, entre outros, evidencia o interesse em compreender a funcionalidade do sufixo $-a$, a manutenção do morfema em determinadas línguas e o seu apagamento em outras. Para o desenvolvimento da presente pesquisa, a seguir, apresentar-se-ão informações relevantes — breve contexto histórico, localização territorial, subconjunto da língua, número de falantes, corpus de pesquisa, entre outras - sobre os três povos e suas respectivas línguas estudadas mais profundamente neste trabalho, mas, na medida da necessidade, serão apresentadas outras línguas ${ }^{4}$ da FLTG.

\subsubsection{Tapirapé}

Os tapirapé foram praticamente dizimados no final da década de 40 por doenças infecto-contagiosas adquiridas pelo contato com os não índios e pelos ataques dos Kayapó Metuktire, grupo guerreiro inimigo (PRAÇA, 2007). Em 1950, com o importante auxílio das Irmãzinhas de Jesus, iniciaram um processo de recuperação populacional, da identidade e de suas terras.

De acordo com Praça (2007), os ãpyãwa, como se autodenominam os tapirapé, eram aproximadamente 600 pessoas, atualmente são $950^{5}$, habitando a Terra Indígena Tapirapé/Karajá e a Terra Indígena Urubu Branco, separadas por cerca de $180 \mathrm{~km}$, localizadas nos municípios de Luciara e Santa Terezinha, no Mato Grosso. Apesar de suas terras serem

\footnotetext{
${ }^{4}$ Quando se fizer menção à língua, o nome terá a primeira letra maiúscula (Nheengatú, Tapirapé, Guajá, Kamaiurá, Tupinambá etc.); quando se fizer menção à etnia, o nome terá a primeira letra minúscula (nheengatú, tapirapé, guajá, kamaiurá, tupinambá etc.).

${ }^{5}$ Dado obtido em comunicação pessoal com Praça (2015).

12
} 
homologadas por decretos e terem finalizado o processo de regulamentação fundiária, a pesquisadora afirma que (PRAÇA, 2007, p. 3):

Muitos Tapirapé estão preocupados com o futuro de suas terras e com a presença constante dos tori "não-índios" nas aldeias. (...) Pelejam diariamente para defender suas terras, as quais são frequentemente invadidas por posseiros, e para manterem-se como uma unidade sociocultural distinta. Associam a língua Tapirapé ao próprio sangue e consideram-na elemento vital para a sobrevivência do seu povo.

De acordo com a classificação de Rodrigues (1984-1985), a língua Tapirapé pertence ao subconjunto $\mathrm{IV}^{6}$ da família linguística Tupí-Guaraní, do tronco Tupi. A plena vitalidade da língua pode ser justificada pelas importantes medidas tomadas pela escola, em que, por exemplo, trabalha-se, primeiramente, a alfabetização em língua materna e, posteriormente, inicia-se o português, assim os ãpyãwa, em sua grande maioria, são bilíngues em Tapirapé e português. Além disso, os alunos das séries finais têm noções fundamentais de linguística aplicada à descrição da própria língua e o corpo docente da Escola Indígena Tapirapé é constituído por professores tapirapé, com formação intercultural apropriada para essa modalidade de ensino.

Para esta pesquisa, o corpus de análise da língua Tapirapé constitui-se, principalmente, dos seguintes trabalhos:

(i) a gramática A língua Tapirapé (ALMEIDA; IRMÃZINHAS DE JESUS \& PAULA, 1983), primeira gramática da língua Tapirapé, fruto de anos de convivência entre as Irmãzinhas de Jesus e da sistematização do linguista português Antônio Almeida. O trabalho apresenta os falantes da língua, bem como os aspectos fonológicos, morfológicos, sintáticos e lexicais dessa língua. Os autores afirmam que a gramática não foi feita para linguistas nem com fins teóricos, mas sim como um instrumento que desperte a consciência dos tapirapé como povo com as suas características e tradições próprias.

(ii) a tese Morfossintaxe da língua Tapirapé (PRAÇA, W. N., 2007), que apresenta uma descrição gramatical da língua Tapirapé, com enfoque em sua morfossintaxe. A linguista baseia-se nos preceitos funcional-tipológicos e os dados linguísticos utilizados na pesquisa foram, em sua grande maioria, coletados em trabalhos de campo realizados nas aldeias tapirapé. No Capítulo 1 da tese, A dupla oposição

\footnotetext{
${ }^{6} \mathrm{O}$ subconjunto IV da família Tupí-Guaraní inclui também: Asuriní do Tocantins, o Avá-Canoeiro, o Guajajára, o Parakanã, o Suruí, o Tembé e o Turiwára (RODRIGUES, 1984-1985).
} 
nome/verbo e argumento/predicado, a autora descreve como nome e verbo desempenham as funções sintáticas de predicado e argumento, sem que haja processos derivacionais promovendo mudança de classe e aborda como é realizada a distinção entre nome e verbo; no capítulo 2, Morfologia transcategorial, seção 2.3, $O$ sufixo -a, Praça descreve o alto grau de produtividade desse morfema no Tapirapé.

\subsubsection{Guajá}

Em 1973, iniciou-se o contato permanente com os guajá; nessa época, somavam-se 600 índios, número este reduzido à metade após as enfermidades trazidas nos primeiros contatos com os não índios. Sob pressão de grupos maiores e mais fortes, foram obrigados a adotar o nomadismo, exploravam as matas do Maranhão em grupos pequenos, tornando difícil reconstruir o parentesco distante dos guajá, uma vez que esses indígenas se dispersaram e ficaram reduzidos a meros fragmentos de sua população original.

De acordo com os dados de Magalhães (2007), atualmente, os awá, como se autodenominam os guajá, são aproximadamente 350 a 400 pessoas, incluindo grupos que vivem sem nenhum contato com indígenas e não indígenas. Localizam-se nas Terras Carú, Alto Turiaçú e Araribóia, no noroeste do estado do Maranhão. Como necessidade, a pesquisadora afirma que (MAGALHÃES, 2007, p. 2):

O povo Guajá depende da floresta para continuar a existir e praticar suas atividades nômades. Sem a floresta seu modo de vida torna-se impossível. A constante presença de madeireiros, caçadores e coletores em suas terras tem destruído a fauna e a flora que os cerca e pode comprometer a sua existência.

De acordo com a classificação de Rodrigues (1984-1985), a língua Guajá pertence ao subconjunto VIII ${ }^{7}$ da família linguística Tupí-Guaraní, do tronco Tupi. Os guajá são ainda predominantemente monolíngues. Sobre a compreensão do português e a capacidade de se comunicar nessa língua, poucos têm esse domínio. Atualmente, participantes do Conselho Indigenista Missionário e da Associação Linguística Evangélica Missionária, com o apoio da Secretaria de Educação do estado, têm permanecido algum tempo em Postos

\footnotetext{
${ }^{7} \mathrm{O}$ subconj

unto VIII da família Tupí-Guaraní inclui também: Takunyapé, o Urubu-Ka’apor, o Wayampí, o Wayampipukú, o Emérillon, o Amanayé, o Anambé, o Turiwára e o Zo’é (RODRIGUES, 1984-1985). 
Indígenas com a intenção de aprender o Guajá e alfabetizá-los em sua língua materna, ao mesmo tempo em que os ajudam a familiarizar-se com o português oral.

Para esta pesquisa, o corpus de análise da língua Guajá constitui-se, principalmente, do seguinte trabalho:

(i) a tese Sobre a morfologia e a sintaxe da língua Guajá (MAGALHÃES, M. M. S., 2007). O trabalho teve como objetivo principal registrar dados do Guajá, descrever e analisar esses dados, interpretando-os à luz do funcionalismo, para realizar um estudo mais amplo e aprofundado da morfologia e da sintaxe da língua. No capítulo 1, Classes de palavras lexicais, a autora descreve as classes de palavras da língua Guajá, observando que, morfologicamente, os nomes caracterizam-se por constituírem a única classe lexical que admite flexão, o que ela chamou de sufixo nominal - $a$; além disso, faz, ainda, outras observações sobre o sufixo - a relacionado a verbos, adjetivos, advérbios e numerais.

\subsubsection{Kamaiurá}

Com base nos estudos de Seki (2000), os kamaiurá relatam que, em tempos antigos, viviam com os tapirapé, mas que deles se separaram para fugir dos ataques de outros índios e dos não índios. Por meio do rio Auaiá Missu, chegaram ao rio Xingu e foram subindo por etapas. Na passagem pelo território Suyá, sofreram repetidos ataques desse povo e também dos jurunas. Depois de passar pelo Morená, chegaram ao Jacaré, no baixo Kuluene, onde encontraram o povo indígena waurá, que os convidou a se juntarem a ele. Prosseguiram, juntamente com os waurá, até a margem esquerda da Lagoa de Ipavu, em um lugar chamado Jamutukuri. Algum tempo depois, os waurá migraram para outra região, permanecendo nessa área apenas os kamaiurá, onde viveram por um longo período. Do Jamutukuri, passaram para o outro lado da Lagoa de Ipavu, onde se distribuíram em quatro aldeias, que teriam sido encontradas, em 1887, pelo etnólogo Karl Von den Steinen.

Em 1887, época em que Karl Von den Steinen esteve em contato com esse povo, a população kamaiurá era de aproximadamente 264 indivíduos. Em 1938, a população somava cerca de 240 pessoas e, em 1954, afetados por uma forte epidemia de sarampo, foram reduzidos a 94 indivíduos. Após esses decréscimos, a população kamaiurá iniciou um processo de crescimento demográfico: aumentou para 131 indivíduos, na década de 1970 (JUNQUEIRA, 2004). 
Os dados de 2009 da Fundação Nacional de Saúde (FUNASA) estimam que os apyap, como se autodenominam os kamaiurá, contam com uma população de 523 indivíduos. Atualmente, se localizam na beira da Lagoa de Ipavu, a $15 \mathrm{~km}$ do rio Kuluene, afluente do Alto Xingu, estado do Mato Grosso.

De acordo com a classificação de Rodrigues (1984-1985), a língua Kamaiurá é a única língua pertencente ao subconjunto VII da família linguística Tupí-Guaraní, do tronco Tupi. Quanto às tradições (KAMAIWRÁ ${ }^{8}, 2010$, p. 22):

O povo Kamaiurá vive a tradição dos antigos: falam a língua kamaiurá como primeira língua, seguem os costumes alimentares e os rituais próprios da cultura Kamaiurá e criam seus filhos dentro desses costumes, mesmo indo à cidade e vestindo roupa, quando saem da aldeia, apesar de 120 anos de contato com não índios (KAMAIWRÁ, 2010, p. 22).

Para esta pesquisa, o corpus de análise da língua Kamaiurá constitui-se, principalmente, do seguinte trabalho:

(i) a Gramática do Kamaiurá (SEKI, 2000) — considerada a primeira moderna gramática descritiva abrangente de uma língua indígena do Brasil escrita por um brasileiro. Nesse trabalho, a autora optou por não adotar uma teoria linguística formal particular. A descrição e a análise da língua abrangem desde a fonologia, a morfologia e a sintaxe da língua até alguns aspectos semânticos e lexicais, incluindo, ainda, textos analisados, mapas e fotos. No capítulo 2, Classes de palavras, a autora discute os critérios usados para estabelecer cada uma das classes, apresentando também, os paradigmas de flexão característicos de algumas delas; no capítulo 3, Fenômenos relacionados a subconstituintes da oração, apresenta o sufixo - a como responsável por marcação de caso, denominado por ela como caso nuclear.

(ii) o artigo Classes de palavras e categorias sintático funcionais em Kamaiurá (SEKI, 2001). Nesse trabalho, a linguista discute algumas questões relativas às categorias lexicais da língua Kamaiurá e às relações entre essas categorias e as categorias sintático-funcionais. Seki demonstra que, nessa língua, não há

8 Aisanain Páltu Kamaiwrá concluiu o doutorado em Linguística e recebeu, com louvor, o título de doutor pela Universidade Brasília, no dia de 28 de maio de 2015. Sua tese de doutorado tem como título "O Kwarýp de Kanutari: uma abordagem Linguística e Etnográfica”. 
neutralidade entre o verbo e o nome, pelo contrário, às classes são distintos morfemas próprios e critérios específicos, sendo eles morfológicos.

\subsection{Morfossintaxe comum entre línguas da FLTG}

Duas ou mais línguas são consideradas geneticamente aparentadas quando compartilham propriedades estruturais e lexicais tais e tantas, que, em seu conjunto, não se possam explicar nem como consequências independentes de princípios universais da linguagem, nem como resultado de um processo de aquisição pelos falantes de uma língua em eventual interação social com os falantes de outra (...) (RODRIGUES, 2011, p. 233).

As línguas da família linguística Tupí-Guaraní compartilham um grande número de propriedades, tanto de estrutura como de léxico. Dietrich (2010) destaca que as línguas da FLTG são, em sua maioria, do tipo aglutinante, ou seja, nomes e verbos podem receber um grande número de sufixos e prefixos, e, ainda, também são capazes de "construírem os falantes sintagmas complexos impressionantes, combinando vários sufixos numa ordem bem estabelecida" (DIETRICH, 2010, p. 19).

Rodrigues (2011), interessado em analisar as relações internas na FLTG, seleciona algumas características como diagnóstico não só para efeito de inclusão de uma língua na família, mas também para exclusão de línguas geneticamente aparentadas. Listadas abaixo, as características mais relevantes para esta pesquisa, retiradas de Rodrigues (2011, p. 236):

(a) prefixos marcadores de sujeito comuns aos verbos intransitivos $\mathrm{e}$ transitivos em orações independentes, incluindo formas iguais a, ou deriváveis fonologicamente de: $a$ - "eu", ere- "você", ja- "eu e você", oro"eu e ele", pe- "você e ele", $o$ - "ele, eles" (também "eu, você e ele");

(b) pronomes pessoais exprimindo possuidor, sujeito de verbos descritivos e objeto direto, assim como sujeito de verbos intransitivos em orações dependentes, incluindo formas iguais a, ou deriváveis fonologicamente de: (i) txe "eu", (e) ne "você", jane "eu e você", ore "eu e ele", pe (ẽ) "você e ele" (também atxe "eu, você e ele");

(c) prefixos relacionais incluindo $r$-, que assinala que o determinante da palavra prefixada e a palavra que a precede imediatamente, aplicável a uma classe de palavras que inclui "olho", "rosto", "lábio inferior", "sangue", "corpo", "folha", "casa", "nome"; p. ex., Tupinambá paye r-esa "olho do paje", xe r-esa "meu olho". 
Somando-se a essas características, Mattos (2015) afirma, ainda, que: as línguas da FLTG podem expressar o plural por meio de afixos, partículas, reduplicação; a negação é expressa por morfologia variada, sendo restrita ao nível dos constituintes oracionais ou negando predicados inteiros, sejam eles de núcleo verbal ou nominal; operações de ajustes de valência (incorporações nominais, causativizações, reflexivizações, estruturas aplicativas e nominalização) podem ser encontradas com frequência nessas línguas; são abundantes partículas desempenhando funções variadas; a ordem dos constituintes nas orações é variável.

\subsubsection{Nome, verbo, argumento, predicado}

Entre as línguas da FLTG, uma das propriedades morfossintáticas mais comuns é o fato de a função predicativa não ser exclusiva de verbos. A hipótese de Queixalós (2006) é que as línguas da FLTG apresentam um padrão de organização morfossintática condizente com o que Launey (1994 apud QUEIXALÓS, 2001), descreveu como omnipredicatividade em seus estudos sobre o Nahuatl. As línguas da FLTG parecem descender de uma língua ancestral comum cujas entradas lexicais das principais classes de palavras tinham como função primária a predicação, sendo a função argumental secundária, derivada da primeira. Como regra geral, nessas línguas os nomes podem instituir núcleo de predicado sem intermediação de verbos copulativos e sem necessidade de morfologia derivacional. Assim, ainda que seja possível distinguir nomes e verbos em razão de seu comportamento morfológico (ver Capítulo 2), nem sempre é possível relacionar sintaticamente essas duas classes de palavras às funções exclusivas de argumento e predicado (ver Capítulo 3), respectivamente. 


\section{AS CLASSES LEXICAIS NOME E VERBO}

Neste capítulo, pelo fato de a funcionalidade do sufixo - $a$ estar, normalmente, associada às categorias lexicais de nomes e verbos, apoio-me na perspectiva semântico lexical de Givón (2001), sobre as classes de palavras, para descrevê-las.

\subsection{Classes de palavras lexicais}

Ao definir classes de palavras, Givón (2001, p. 44) divide o vocabulário das línguas em palavras lexicais (de conteúdo) e palavras não lexicais (de função). As palavras lexicais codificam conceitos estáveis e compartilhados no universo físico, cultural e interno, representado em poucas e grandes classes, relativamente abertas, pois, com o decorrer do tempo e do espaço, podem entrar novos participantes nessas classes e participantes velhos podem sair, à medida que palavras novas vão sendo criadas ou as antigas vão sendo ressignificadas. Já as palavras não lexicais não expressam conteúdo propriamente dito, mas trabalham a serviço da articulação do discurso, codificam funções gramaticais e são representadas por muitas e pequenas classes, relativamente fechadas.

Nomes, verbos, adjetivos e advérbios são as quatro classes principais de palavras lexicais nas línguas. Os advérbios não formam uma classe sintática, semântica e morfologicamente homogênea. A partir da noção de protótipo, em oposição ao sistema tradicional de características distintas, Givón (2001) defende que a inclusão de participantes em uma determinada classe depende não apenas, mas também de critérios: (i) semânticos: que tipo de significado tende a ser codificado por cada classe particular (os mais universalmente previsíveis); (ii) morfofonológicos: que tipo de morfemas gramaticais e derivacionais tendem a se unir a uma determinada classe de palavras (os mais variáveis translinguisticamente); (iii) sintáticos: que posições e funções típicas na sentença as palavras de uma classe particular tendem a desempenhar na oração (GIVÓN, 2001, p. 49).

Um conjunto de quatro critérios semânticos, relacionados entre si, é elencado por Givón (2001, p. 50) para separar as classes dos nomes, adjetivos e verbos: estabilidade temporal (nível de modificação de uma entidade ao longo do tempo), complexidade (quantidade de características definidoras), concretude física e compacidade espacial. Esses critérios são representados por uma distribuição sistemática dessas classes através de uma 
dimensão semântica coerente denominada time-stability scale, representada pelo autor da seguinte forma:

most stable.

least stable

tree, green

sad, know

work

shoot

noun adj

adj verb

verb

verb

Tabela 1. Escala de estabilidade temporal de Givón (2001, p. 54).

A análise da escala sugere que experiências ou fenômenos relativamente estáveis, através do tempo, tendem a ser lexicalizados nas línguas como nomes. Assim, no extremo mais estável da escala estão os nomes mais prototípicos, pois denotam entidades concretas, formadas por um conjunto de muitos traços associados entre si, feitas de matéria relativamente durável e compactas em termos espaciais (como tree 'árvore'). No outro extremo da escala, encontram-se os verbos mais prototípicos, que envolvem experiências de curta duração e codificam mudanças rápidas no estado (como shoot 'atirar'), na condição ou na localização espacial de entidades codificadas por nomes.

As classes dos nomes e dos verbos, os dois extremos na escala de estabilidade de Givón (2001), são atestadas nas línguas indígenas Tapirapé, Guajá, Kamaiurá, Tupinambá, Nheengatu, entre outras. No entanto, essa generalização é problemática para a classe dos adjetivos: nas línguas em que se atesta a existência dessa classe de palavras (por meio de características semânticas e morfológicas e por meio de distribuição sintática), ela ocupa, segundo Givón, a parte intermediária da escala, em que costuma abarcar pelo menos as propriedades físicas mais estáveis dos nomes prototípicos, como tamanho, forma, cor, consistência, textura, peso, cheiro e sabor.

Assim, os adjetivos prototípicos são conceitos abstraídos de entidades codificadas como nomes e exprimem as propriedades físicas duráveis destes, ocupando, por um lado, o mesmo extremo estável da escala de estabilidade temporal que eles. No entanto, por outro lado, diferentemente dos nomes, os adjetivos mais prototípicos denotam conceitos simples, o que os torna mais abstratos e com menor estabilidade temporal que aqueles. Do outro lado da escala, os adjetivos menos prototípicos fazem fronteira com os verbos menos prototípicos, abarcando uma grande parte dos fenômenos que denotam estados temporários, como temperatura ou estados de saúde. 
A noção adjetival constitui um conceito lexical, o qual diz respeito à maneira como uma sociedade recorta seu universo experimental em termos de categorização linguística (GIVÓN, 2001). Tal noção pode ser, no entanto, categorizada de diferentes maneiras entre as línguas do mundo. De acordo com Dixon (1977), o adjetivo nem sempre se constitui como categoria lexical independente nas línguas. Segundo o autor, muitas vezes a noção adjetival pode ser expressa por meio de uma categoria nominal, ou mesmo de uma categoria verbal, dependendo do sistema linguístico em questão.

A morfologia gramatical é, segundo Givon (2001), critério igualmente forte para definir o pertencimento de uma raiz a uma determinada classe. A morfologia associada aos nomes inclui marcadores de gênero e classificadores, marcadores de número, artigos, marcas de caso em âmbito semântico (agente, paciente etc.) ou sintático (sujeito, objeto etc.), pronomes possessivos. As características morfológicas mais comumente associadas aos verbos incluem tempo, aspecto e modalidade, negação, pronomes e concordância (com ou sem pronomes) e morfologia de ajustes de valência, entre outras.

Em geral, nas línguas da FLTG, utiliza-se como critério morfológico para distinguir nomes e verbos a observação tipológica de que verbos tendem a receber morfologia aspecto-temporal, enquanto nomes seriam incompatíveis com essas marcas. As especificidades das línguas em análise nesta pesquisa serão exploradas na próxima seção.

\subsection{As classes lexicais em Tapirapé}

Na língua Tapirapé, apesar da semelhança entre essas classes, nomes e verbos podem ser identificados como duas classes lexicais distintas com base em critérios morfológicos. Os verbos (ver seção 2.2.1) podem receber o sufixo -ãw (-ãw -tãw) 'nominalização de processo, instrumento, local', os prefixos de imperativo $e$ - '2sg' e pe'2pl', em orações afirmativas, e também os prefixos de imperativo ere- '2sg' e pexe- '2pl', em orações negativas. Os nomes (ver seção 2.2.2) podem receber os sufixos de 'passado nominal' e 'futuro nominal', -kwer (-kwer -wer -er) ${ }^{9}$ e -rym, e os morfemas -ryn 'similaridade' e ymyn 'velho'.

Em um nível morfossintático, a possibilidade ou não de ocorrência de morfemas específicos de cada classe permite por si só caracterizar nomes e verbos.

\footnotetext{
${ }^{9} \mathrm{O}$ sufixo -kwer, do Tapirapé, compartilha propriedades com a forma -kwera do Nheengatú, que designa qualquer entidade que tenha perdido parte de suas propriedades, podendo funcionar como núcleo do sintagma nominal em função argumental ou em função de predicado nominal. Compartilha também com o sufixo -mi 'caduco', do Baniwa. Essas formas, associadas a um sintagma verbal, -mi e -kwera se referem a uma ação que já não é válida no momento de enunciar (CRUZ, 2011).
} 


\subsubsection{Verbos}

De acordo com Praça (2007), na língua Tapirapé, essa classe é constituída pelos seguintes tipos de verbos: intransitivos ativos, descritivos e transitivos. Os verbos diferenciam-se com base na utilização dos marcadores de pessoa das séries I e II, cujos paradigmas são demonstrados pela autora da seguinte forma:

\begin{tabular}{|l|l|l|}
\hline & Série I & Série II \\
\hline 1 sg & ã- & Xe \\
\hline 1 incl & xi- & Xane \\
\hline 1 excl & ara- & Are \\
\hline 2 sg & ere- & ne \\
\hline $\mathbf{2 p l}$ & pe- & Pe \\
\hline 3 & a- & i- $\sim-\sim$ t- $\sim$ h- \\
\hline
\end{tabular}

Tabela 2. Marcadores de pessoa das séries I e II do Tapirapé (PRAÇA, 2007, p. 96).

A classe geral dos verbos é identificada pela propriedade de seus membros poderem receber o sufixo -ãw (-ãw -tãw) 'nominalização de processo, instrumento, local'. Esse sufixo nominaliza verbos ativos, transitivos e intransitivos, bem como verbos descritivos, ou seja, altera a categoria gramatical de verbo em nome, como pode-se perceber nos exemplos apresentados por Praça (2007, p. 22):

(01) tãxão- $\varnothing \quad$ $\quad$-xokã-ãw-a $\quad$ i-kãto

porcão-X X-matar-N.PROC-X 3.II-ser.bom

'a matança dos porcões foi boa'

(02) ie-Ø ã-ino-patãr i-xe’eg-ãw-a

1sg-X 1sg.I-ouvir-querer 3.II-falar-N.PROC-X

'eu quero ouvir a fala dela (lit. 'eu quero ouvir a falação dela')

(03) ie- $\varnothing \quad n=\tilde{a}-j x a ̃ k-i \quad n e=\varnothing-k a n e ' \tilde{o}-a ̃ w-a$

1sg-X não=1sg.I-ver-NEG 2sg.II=R-ser.cansado-N.PROC-X

'eu não vi seu cansaço' 
Somente aos verbos, também, é dada a possibilidade de receberem os prefixos de imperativo $e$ - '2sg' e pe- '2pl', que ocorrem, de acordo com Praça (2007), em orações afirmativas:

(04) e-par-o

2sg.IMP-sair-INT

'saia rápido'

(05) pe-kyrã

2pl.IMP-ser.gordo

'sejam gordos'

E também os prefixos de imperativo ere- '2sg' e pexe- '2pl', os quais ocorrem, de acordo com Praça (2007), em orações negativas, sendo que a negação é feita pela partícula clítica ewi:

(06) wãkiri, ere-ker=ewi

Walkíria, 2sg.IMP-dormir=NEG

'Walkíria, não durma'

(07) pexex-ary-xaryw=ewi

2pl.IMP-alegria-REDUP=NEG

'não fiquem alegres'

\subsubsection{Nomes}

Os nomes lexicais, em Tapirapé, a partir de suas características morfossintáticas de poderem ou não se combinar com uma expressão referencial, são divididos em três tipos: nomes relativos, autônomos e absolutos.

Para Praça (2007, p. 56-61), os nomes relativos ${ }^{10}$ (08) funcionam como nomes "presos", mantendo uma relação intrínseca com uma expressão referencial, não ocorrendo sem marcadores pessoais ou sintagmas nominais que os modifiquem (ex. membros do corpo, relações de parentesco, conceitos ligados aos seres vivos). Os nomes autônomos (09) admitem

10 "Nomes relativos" também são conhecidos por "nomes inalienavelmente possuídos" (RODRIGUES, 1996; 2001; SEKI, 2001). 
uma expressão referencial como complemento adnominal, entretanto sua ocorrência não é sistematicamente obrigatória como no caso dos nomes relativos (ex. artefatos domésticos, armas, ferramentas e adornos). Já os nomes absolutos não mantêm relação com uma expressão referencial e apenas excepcionalmente admitem a indicação de um possuidor (ex. membros da sociedade, elementos e fenômenos da natureza, formações geográficas, animais, plantas). No exemplo (10) verifica-se que nomes absolutos não humanos podem ser possuídos, apesar de não ser frequente ${ }^{11}$.

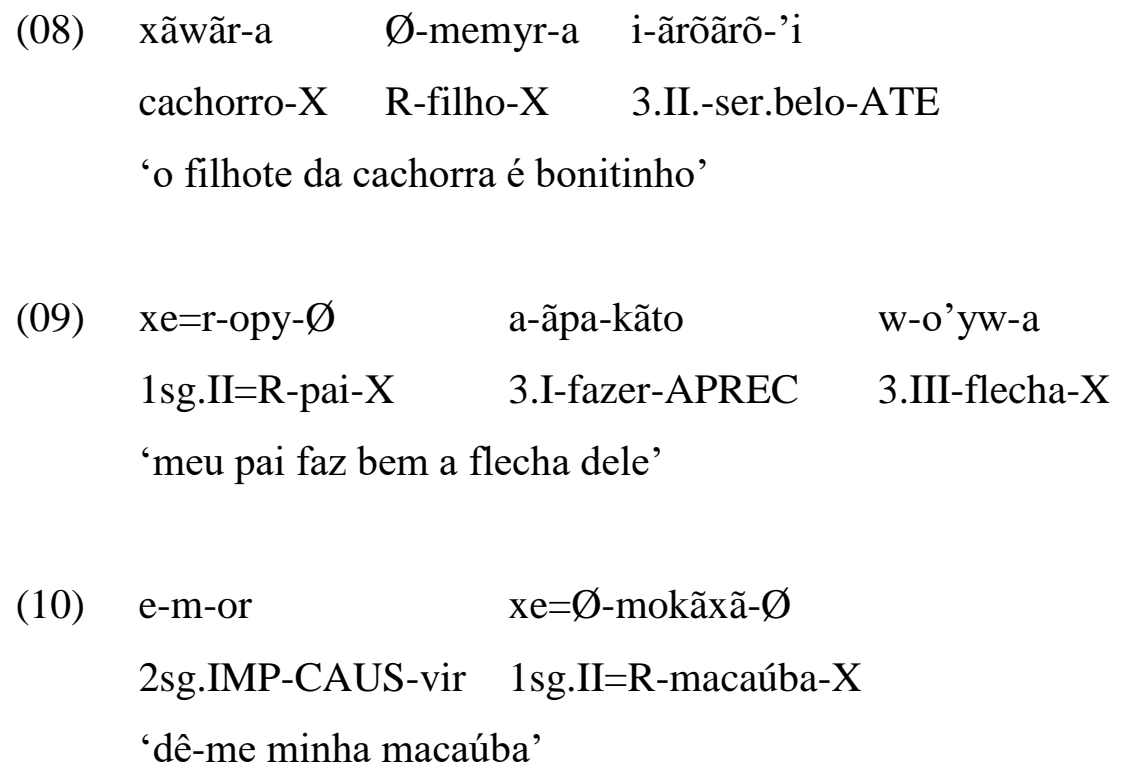

O nome, em Tapirapé, é identificado pela propriedade de receber os sufixos kwer (-kwer -wer -er) e -rym, conhecidos por 'passado nominal' e 'futuro nominal', respectivamente ${ }^{12}$, e pelos morfemas -ryn 'similaridade' e -ymyn 'velho', vetados aos verbos.

O passado nominal (-kwer), a partir da definição de Praça (2007, p. 19), exprime uma ideia de caduquice, de prescrição de uma referida entidade. Do ponto de vista sintático, o nome flexionado com o referido morfema ocorre como núcleo de sintagma nominal ou núcleo do predicado existencial:
$\varnothing$-exã'ẽ-kwer-a
i-ky’ã 'yn-a paej-tãj-pe
3.II-panela-PN-X
3.II-ser sujo
3.sentar-GER-X
lavar-N.PROC-LOC
'a ex-panela dela está suja na pia'

\footnotetext{
${ }^{11}$ Para o exemplo (10), Praça (2007, p. 61) descreve a situação como "uma menina estava comendo um coco (macaúba), neste interim seu irmãozinho mais velho veio correndo e o tomou de sua mão. Imediatamente ela o solicitou de volta:(...)".

12 ALMEIDA; IRMÃZINHAS DE JESUS \& PAULA, 1983. SEKI, 2000; 2001. PRAÇA, 2007. 24
} 
O futuro nominal -rym, de acordo com Praça (2007, p. 20), exprime uma ideia de 'vir a ser', ou melhor, de projeção do que está destinado. Provavelmente por uma questão semântica, a autora afirma que o nome marcado com esse sufixo não institui núcleo de predicado existencial. Sintaticamente, o nome sufixado também exerce a função de núcleo do sintagma nominal:

xe=r-o'-rym-ã a-pen

1sg.II=R-flecha-FN-X 3.I-quebrar

'a minha futura flecha quebrou'

(14) ie- $\varnothing$ rãka ã-pyyk t-yro- $\varnothing \quad$ wex-yro-rym-a

1sg-X PAS.REC 1sg.I-comprar 3.II-invólucro-X 1sg.III-invólucro-FN-X

'eu comprei tecido que será minha roupa'

Semanticamente, o sufixo -ryn denota, de acordo com Praça (2007, p. 21), ideia de similaridade, ou seja, determinada entidade tem qualidade ou caráter de ser similar a outra. Tal sufixo deriva nomes que podem exercer as funções de núcleos de sintagmas nominais e de predicados existenciais:

mãir-a mĩ a-’o xety-ryn-a

não.índio-X HAB 3.I-comer batata.doce-SI-X

'o não-índio sempre come batatinha'

(16)

miã-ryn

veado-SI

'cabra' (lit. '(existe) cabra')

O sufixo -ymyn 'velho' (PRAÇA, 2007, p. 21), que não se aplica a seres humanos, expressa juízo de valor sobre determinada entidade, quanto às suas características antiquadas, obsoletas ou gastas pelo uso. No plano sintático, o nome derivado ocorre como núcleo de sintagma nominal e como núcleo do predicado existencial: 
Ø-'oyw-ymyn-a a-pen

3.II-flecha-VEL-X 3.I-quebrar

'a flecha velha dele quebrou'

(18) xe=r-o’ypepakyxiãw-ymyn

1sg.II-R-tesoura-VEL

'eu tenho tesoura velha' (lit. 'existe minha tesoura velha')

\subsection{As classes lexicais em Guajá}

As classes lexicais dos nomes e dos verbos são diferenciadas no Guajá por meio de critérios semânticos, pela distribuição sintática — pois, apesar de cada uma ter significado próprio, o comportamento de certos lexemas revela uma predisposição para certas funções sintáticas — e também por meio de critérios morfológicos.

Quanto aos critérios morfológicos (MAGALHÃES, 2007), os verbos (ver seção 2.3.1), quando transitivos, recebem sufixo nominalizador de agente, -(a)há(r), prefixo nominalizador de paciente com referência necessária ao agente, imi-, sufixo nominalizador de paciente sem referência ao agente, -(i)pýr, sufixo causativo -(a)ká. e recebem, ainda, prefixos pessoais combinados a pronomes clíticos quando há hierarquia de pessoa. Quando intransitivos, recebem o sufixo nominalizador -ma'á e o prefixo causativo $m i$-. Os nomes (ver seção 2.3.2) caracterizam-se por admitirem flexão com o sufixo nominal $-a$, com o sufixo casual locativo -pe e, também, por receberem os sufixos de atualização nominal, -kér-e -rỹm.

\subsubsection{Verbos}

Os verbos são classificados como transitivos e intransitivos, conforme o número de argumentos que admitem, sendo que cada um desses tipos contém verbos que podem ocorrer com ou sem complementos. Além da valência, as duas subclasses diferenciamse também por meio de processos morfológicos específicos de cada uma.

Os verbos transitivos recebem afixos nominalizadores próprios, de acordo com Magalhães (2007, p. 186), quais sejam: “sufixo nominalizador de agente, -(a)há(r), o prefixo nominalizador de paciente com referência necessária ao agente, imi- e o sufixo nominalizador de paciente sem referência ao agente, -(i)pýr" e recebem, ainda, o sufixo causativo -(a)ká: 
(19) t-ãj Ø-’ók-ahár-a

R4-dente R1-arrancar-NZR-X

'arrancador de dentes/dentista'

(20) Maí r-imi-japo-kér-a

Maíra R1-NZR-fazer/criar-RETR-X

'criatura de Maíra'

(21) iká-pyr-y’ým-a $\quad \varnothing$-wyhý ka’á r-ipí

matar-NZR-NEG-X 3-correr mato R1-por

'o (veado) que não foi matado fugiu pelo mato'

(22)
há=Ø-py’ýr-a
a-xak-aká tá ni=Ø-pé
$1=\mathrm{R} 1$-pulseira- $\mathrm{X}$
1-ver-CAUS PROJ 2=R1-para

'vou mostrar minha pulseira para você'

Os verbos intransitivos diferenciam-se dos transitivos por receberem o sufixo nominalizador -ma'á, que resulta em nomes de agente, e o prefixo causativo $m i^{-13} \sim m o-\sim m$ (MAGALHÃES, 2007, p. 187):

(23) ijã-ma’á

cantar-NZR

'cantor'

(24) a-mi-me'ẽ kamẽ

2/IMP-CAUS-olhar PROIB

'não o acorde!'

Quando há hierarquia de pessoa, os verbos transitivos do Guajá, de acordo com Magalhães (2007, p. 19), podem ser flexionados também por prefixos relacionais combinados a pronomes clíticos, mas constituem a única classe lexical que admite ser flexionada por prefixos pessoais:

${ }^{13}$ Em Tapirapé, o prefixo causativo $m a$ - acrescenta-se a nomes, verbos descritivos e verbos intransitivos ativos. 
(25)

nijã ha=r-ixá

você $1=\mathrm{R}^{1}$-ver

'você me viu'

(26) jahá a-xá

eu 1 -ver

'eu (o) vi'

\subsubsection{Nomes}

Segundo Magalhães (2007, p. 149), no Guajá, os nomes podem ser subdivididos em três tipos: nomes com determinante obrigatório, nomes com determinante facultativo e nomes sem determinante.

Começando pelos nomes com determinante obrigatório, eles são os que designam partes de um todo e membros de um sistema de relações, pressupondo um determinante a que se relacionam necessariamente, sempre acompanhados de prefixos relacionais. Os nomes com determinante obrigatório classificam-se em: qualificadores e dêiticos de posição, como mostram alguns dos exemplos de Magalhães (2007, p. 152-156):

Xa'ahõxiká-mỹn-a $\quad$-inẽ ha-jpá-pe

Xa'ahõxiká-falecido-X 3-permanecer.sentado $\quad \mathrm{R}^{2}$-casa-LOC

'a falecida/antiga Xa'ahõxiká permanecia na casa dela'

(28) kawá-puhú-a a-rukú tá

vasilha-nova-X 1-ter PROJ

'eu quero ter uma vasilha nova'

Os exemplos (27) e (28) apresentam algumas ocorrências dos nomes qualificadores. Além de -mỹn- 'antigo/falecido' e -puhú- 'novo' (para objetos), são também nomes qualificadores: -marér- 'velho' (para objetos), -xa'akér- -xa'áer- 'velho' (para objetos/seres animados), -urý- 'novo' (para seres animados), -ma'akér- 'pequeno', -pý'primeiro', -wahý- 'mulher/fêmea', -wanihã- 'homem/macho'.

Os nomes dêiticos de posição são: -itarỹ 'frente', -meté 'meio', -akwé 'atrás' e -akarỹ 'em direção a': 
Ø-tỹ waxí-a $\quad$ tyrymỹ $\quad$-meté $\quad$ r-ipí

3-plantar milho-X mandioca $\quad \mathrm{R}^{1}$-meio $\quad \mathrm{R}^{1}$-por

'plantou o milho pelo meio da (plantação de) mandioca'

(30) Ø-wẽ $\quad$ h-atá h-akwé $\quad$-kytyrý

3-permanecer deitado $\quad \mathrm{R}^{2}$-fogo $\quad \mathrm{R}^{2}$-trás $\quad \mathrm{R}^{1}$-para

'o fogo dele permaneceu para trás'

O segundo tipo de nomes, os nomes com determinante facultativo, são aqueles que ora admitem determinantes, ora ocorrem sem eles. De acordo com Magalhães (2007, p. 156), no primeiro caso, flexionam-se com os prefixos relacionais, que relacionam o nome ao seu determinante, especificando-o:

(31) a-rú há=Ø-kawá- Ø

2/IMP-trazer $\quad 1=\mathrm{R}^{1}$-vasilha-X

'traga minha vasilha!'

(32) n=a-xak-í i-kanẽ-a

$\mathrm{NEG}=1$-ver-NEG $\quad \mathrm{R}^{2}$-lanterna-X

'não vi a lanterna dele'

Quando ocorrem sem determinantes, não recebem prefixos e referem-se a um termo genérico, que representa uma classe, e não a um objeto específico:

(33) jahá a-jú ka’á r-iá

eu 1-vir mata $\mathrm{R}^{1}-\mathrm{ABL}$

'eu vim da mata'

(34) awá-wahý-ury-hú-a kahá ni=Ø-japó-kwá-j

Guajá-mulher-novo-INTS-X rede NEG=3-fazer-saber-NEG

'a mulher Guajá muito nova não sabe fazer rede'

Por fim, os nomes sem determinante não se flexionam com os prefixos relacionais. Conforme Magalhães (2007, p. 158), “denominam elementos da natureza como plantas (irapa'ý 'pau d'arco', iraro’ý 'andiroba'), animais (tatú 'tatu',jawaruhú 'onça'), 
minerais (itá 'pedra', 'ý 'água'), fenômenos naturais, corpos celestes, acidentes geográficos e, ainda classes de seres humanos".

Morfologicamente, os nomes caracterizam-se por constituírem a única classe lexical que admite flexão com o sufixo nominal $-a$, com o sufixo casual locativo e, também, que recebe os sufixos de atualização nominal, -kér- e -rỹm-, o que os diferencia dos verbos, dos adjetivos e dos numerais.

\subsection{As classes lexicais em Kamaiurá}

As classes lexicais dos nomes e dos verbos são diferenciadas no Kamaiurá por critérios sintáticos e morfológicos, utilizando-se de parâmetros que investigam a possibilidade ou não de ocorrência dos elementos das diferentes classes com certos tipos de afixos. Os verbos (ver seção 2.4.1) se flexionam por meio de elementos pronominais, sufixos que marcam modo e o sufixo nominalizador -tap 'nome de ação'. Os nomes (ver seção 2.4.2) recebem sufixos casuais e o sufixo -het 'passado nominal'.

\subsubsection{Verbos}

Segundo Seki (1997; 2000), o verbo é flexionado por meio de elementos pronominais (prefixos pessoais específicos, prefixos relacionais e pronomes clíticos) e de sufixos que marcam modo. $\mathrm{O}$ verbo se identifica também pela possibilidade de receber o sufixo nominalizador -tap 'nome de ação'. Em Kamaiurá, há uma distinção entre verbos transitivos e intransitivos, e estes últimos se subdividem em ativos e descritivos.

Os verbos transitivos se distinguem morfossintaticamente de outros verbos e de elementos de outras classes de palavras pela capacidade de receberem:

(i) os prefixos da série IV (oro- ' 2 a p. sing.' e opo- ' $2^{\mathrm{a}}$ p. pl.);

(ii) os nominalizadores -tat 'agentivo', -ipyt' 'paciente' e -emi 'paciente/objeto';

(iii) o sufixo -ukat 'causativo'.

Alguns exemplos de verbos transitivos apresentados por Seki (2001, p. 49) são:

-juka

matar

'matar' 
(36)

-juka-tat

matar-Agen.

'o que matou $\mathrm{x}$ '

(37) -juka-pyret

matar-Pac.

'o que foi morto'

(38) -emi-juka

Pac./obj.-matar

'o que x matou'

Os verbos intransitivos ativos marcam a categoria de pessoa com os prefixos pessoais da série I (a- ' $1^{\mathrm{a}}$ p. sing.'; ere- '2 ${ }^{\mathrm{a}}$ p. sing.'; já- ' $1^{\mathrm{a}}$ p. incl.'; oro- ' $1^{\mathrm{a}}$ p. excl..'; pe- '2 $2^{\mathrm{a}}$ p. pl.'; $o$ - ' 3 a p.'), no que se assemelham aos transitivos. No entanto, diferentemente destes:

(i) não são compatíveis com os prefixos da série IV;

(ii) não admitem os pronomes clíticos nos modos independentes;

(iii) no modo gerúndio vêm prefixados com as formas da série II, que somente ocorrem com verbos intransitivos.

(39) kunu'um-a o-jae’o

menino-X 3-chorar

'o menino chora'

Seki (2000) os caracteriza ainda pelo fato de serem nominalizados com os morfemas -ama'e 'atributivo' e -uma'e 'atributivo negativo', não compatíveis com os verbos transitivos.

Essa classe contém predominantemente verbos que implicam volição e controle por parte do participante, como -je'ey 'falar', -jan 'correr', - 'ata 'andar', -karu 'comer', -maraka 'cantar', mas inclui também verbos como -mañ 'morrer', -in 'estar sentado', -kyje ‘ter medo' (SEKI, 2000, p. 66).

Em Kamaiurá, há um verbo - eko 'ser, estar, ficar', que, além de ocorrer como verbo locativo, funciona também como cópula e como auxiliar. O verbo - eko é flexionado em geral como um verbo intransitivo ativo e sofre os mesmos processos derivacionais. Quando é 
verbo locativo, o verbo - eko recebe flexão normal para todas as pessoas, e Seki (2000) afirma que, geralmente, é traduzido para o português como 'estar':

(40) 'am a-ko ikue=we

aqui 1 sg-estar ontem $=$ Retr

'estou aqui desde ontem'

(41) mam tataw-a r-eko-w

onde N.pr-X Rel-estar-Circ

'onde está o Tatap?'

(42) n=o-ko-ite

$\mathrm{Neg}=3$ sg-estar-Neg

'ela não está'

Quando usado como cópula, com o sentido de 'ser', é também flexionado para pessoa como um verbo intransitivo ativo, porém não apresenta a forma regular correspondente à terceira pessoa, marcada com o prefixo $o$-. Em seu lugar, é usado o demonstrativo $a^{\prime} e$, sufixado com -ram 'atributivo':

(43) kara'iw-a a-ko

não-índio-X 1sg-Cóp

'eu sou não-índio

(44) kara'iw-a a'e-ram

kara'iw-X Dem-Atr

'ele é não índio’

\subsubsection{Nomes}

No Kamaiurá (SEKI, 2000), os nomes se identificam morfologicamente pela propriedade de receber sufixos casuais e o sufixo -het 'passado nominal'. Essa classe se subdivide em nomes possuíveis inalienáveis, nomes possuíveis alienáveis e nomes não possuíveis. 
De acordo com Seki (2001, p. 44), os nomes podem ser "inalienavelmente possuídos vêm sempre acompanhados de prefixos relacionais em sua forma normal; os nomes alienavelmente possuídos podem ocorrer ou não com prefixos relacionais e os nomes não possuídos não admitem tais prefixos". Não há marcadores específicos para cada uma dessas subclasses, o contraste entre elas se manifesta no comportamento de seus membros em relação à expressão de posse.

São quatros os prefixos relacionais, cujo uso depende:

(i) da função gramatical que o possuidor tem na locução;

(ii) do tipo de construção;

(iii) do tipo de referência expressa.

O prefixo $o$ - "codifica um possuidor de terceira pessoa correferente ao sujeito da mesma oração ou de uma anterior" (SEKI, 2001, p. 45) Ocorre com nomes possuíveis de qualquer subclasse, realizando-se como $w$ - ao preceder vogal átona:

$$
\begin{aligned}
& \text { w-a'yr-a nite i-jo-w } \\
& \text { 3-filho-X. Com. } 3 \text {-ir-Circ } \\
& \text { 'ele foi com seu (próprio) filho }
\end{aligned}
$$

O prefixo $r$ - ocorre sempre que "o possuidor é codificado por uma expressão referencial posicionada imediatamente antes" (SEKI, 2001, p. 45):

$$
\begin{aligned}
& \text { (46) kunu'um-a r-up } \\
& \text { Menino-X Rel-pai } \\
& \text { 'pai do menino' }
\end{aligned}
$$

O prefixo $i$ - "codifica um possuidor de terceira pessoa especificada, mencionada anteriormente ou que é de alguma forma conhecida pelo contexto e que é não coreferente ao sujeito da oração" (SEKI, 2001, p. 46):

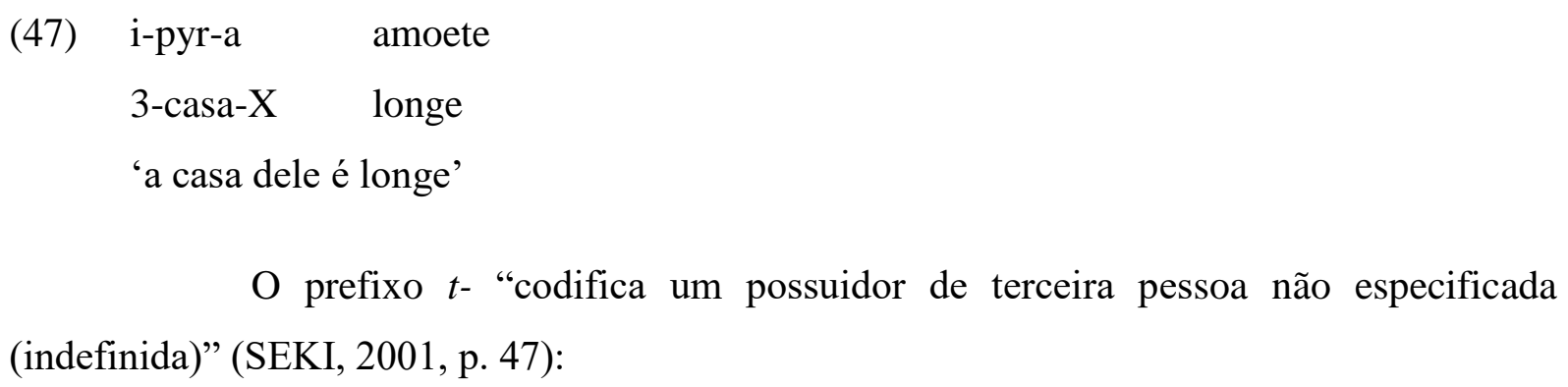


t-er-a i-'arõ-ma'e-a rehe a-ko je=Ø-memyrake-a r-er-am

3i-nome-X 3-bonito-Nzd-X Posp1sg-Cóp 1sg=Rel-filho-X Rel-nome-Atr

'estou em busca de um nome bonito para ser o nome do meu filho'

\subsection{Palavras com semântica adjetival}

São mencionadas na literatura sobre as línguas Tupí-Guaraní ora como "nomes de qualidades" (Rodrigues, 2001a, para o Tupinambá), ora como "substantivos" (Dietrich, 2001, para as línguas da família Tupí-Guaraní), ora como "verbos descritivos" (Seki 2000, para o Kamaiurá e Jensen 1989, para o Wayampi), ora como "classe dos estados", Queixalós 2006, para a família Tupí-Guaraní).

(MAGALHÃES, 2007, p. 20)

A afirmação de Magalhães (2007) pode ser atestada nas línguas Tapirapé, Guajá e Kamaiurá, em que essas raízes lexicais são analisadas e se comportam de maneiras diferentes.

\subsubsection{Tapirapé}

Na língua Tapirapé, Praça (2000) não menciona uma classe de adjetivos para a língua, no entanto apresenta os verbos descritivos, subclasse dos intransitivos, como sendo os que exprimem conceitos que denotam qualidades em geral, incluindo conceitos como: “a) dimensão: ser comprido, ser alto; b) valor: ser bom, ser bonito; c) cores: branco, amarelo, vermelho; d) propriedades físicas: ser duro, ser quente, ser doce; além de sensações psíquicas, como: estar alegre e estar triste" (PRAÇA, 2000, p. 99) ${ }^{14}$.

Essa subclasse indica a categoria de pessoa por meio dos marcadores da série II, (49), podendo ser nominalizados pelo sufixo - $\tilde{a} w$, (50), e receber os prefixos imperativos, (51):

$$
\begin{array}{ll}
\text { tokyn-a } & \text { i-kywer } \\
\text { Tokyna-X } & \text { 3.II.ser. magra }
\end{array}
$$

'Tokyna é magra'

wãkiri ne=Ø-kywe-ãw-a i-ãi-ãiw

Walkíria 2sg.II=R-ser.magro-N.PROC-X 3.I.ser.feio-REDUP

\footnotetext{
${ }^{14}$ Apesar de não fazer referência aos tipos semânticos propostos por Dixon (1977), Praça (2000) sugere alguns conceitos semânticos para a língua Tapirapé semelhantes aos estabelecidos por ele. 
'Walkíria, seu emagrecimento é muito feio'

(51)

ere-xinik=ewi

2sg.IMP-ser.triste=NEG

'não fique triste'

\subsubsection{Guajá}

No Guajá, Magalhães (2007) afirma que a classe dos adjetivos encontra-se numa posição semântica intermediária na escala de estabilidade temporal proposta por Givón (2000) (ver seção 2.1). Já na análise de Dixon (1977, p. 16), que sugere sete tipos semânticos, dentre muitos outros, capazes de compor a classe dos adjetivos para as línguas que justificam a existência dessa classe, a linguista inclui entre os adjetivos temas pertencentes a seis tipos semânticos, não apresentando temas ao tipo semântico 'propensão humana'15.

\begin{tabular}{|c|c|}
\hline Tipos semânticos & Adjetivos em Guajá \\
\hline Dimensão & -amãj 'grande/largo',japa'a 'curto/baixo, -mukú 'comprido/alto' \\
\hline $\begin{array}{l}\text { Propriedade } \\
\text { física }\end{array}$ & 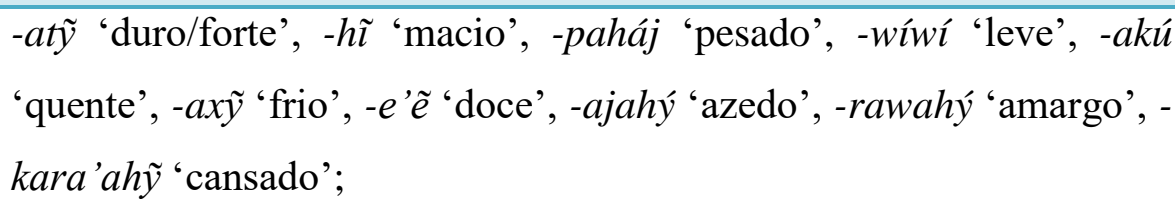 \\
\hline Cor & $\begin{array}{l}\text {-tawahú 'amarelo', -xũ 'branco', -pinuhũ 'preto', -pirỹ 'vermelho', - } \\
\text { awyhú 'azul'; }\end{array}$ \\
\hline Idade & -wajá 'novo/jovem’; \\
\hline Valor & -parahỹ 'bom/perfeito', -manyhỹ 'ruim/imperfeito/estragado'; \\
\hline Velocidade & -apáj ‘rápido’, -mé 'devagar’ \\
\hline
\end{tabular}

Tabela 3. Tipos semânticos para os adjetivos, propostos por Dixon, aplicados aos adjetivos no Guajá (DIXON, 1977 apud MAGALHÃES, 2007, p. 20).

Morfologicamente, a classe dos adjetivos admite flexão relacional, não admitindo flexão pessoal nem flexão com o sufixo - $a$. No Guajá, portanto, os adjetivos compartilham mais características de verbos do que de nomes. Esse fenômeno é confirmado

15 “Temas que são classificados semanticamente por Dixon como 'propensão humana' pertencem todos à classe dos verbos, já que se flexionam com prefixos pessoais, diferindo portanto dos anteriores” (MAGALHÃES, 2007, p. 21). 
em trabalho posterior de Magalhães e Mattos (2014), sobre as classes de palavras no Guajá, cujas autoras descrevem os verbos estativos como os que exprimem conceitos que abarcam desde as propriedades físicas mais estáveis dos nomes, como tamanho, forma, cor, consistência, textura, peso, cheiro e sabor, até uma grande parte dos fenômenos que denotam estados temporários, como temperatura ou estados de saúde.

\subsubsection{Kamaiurá}

Utilizando-se de mesma base de análise, na língua Kamaiurá, Seki (2000) apresenta os sete tipos semânticos propostos por Dixon (1977, p. 16) para a classe adjetivo para exemplificar os verbos descritivos, que trariam, segundo ela, "conceitos que em Português e outras línguas indo-europeias são expressos por adjetivos” (SEKI, 2000, p. 67).

\begin{tabular}{|l|l|}
\hline \multicolumn{1}{|c|}{ Tipos semânticos } & Verbos descritivos em Kamaiurá \\
\hline Dimensão & -atua 'i 'baixo', -je 'ya 'alto', -huku 'comprido'; \\
\hline Propriedade & -akup 'quente', -atã 'duro', -pyw 'macio'; \\
\hline Cor & -jup 'amarelo', -tsiy ‘branco', -pitsun 'preto'; \\
\hline Propensão humana & -oryp 'alegre', -koay 'zangado'; \\
\hline Idade & -myrã 'velho', -pyau 'novo'; \\
\hline Valor & -katu 'bom', -arõ 'bonito, gostoso'; \\
\hline Velocidade & -tykwara'ip 'apressado' \\
\hline
\end{tabular}

Tabela 4. Tipos semânticos para os adjetivos, propostos por Dixon, aplicados aos verbos descritivos do Kamaiurá (DIXON, 1977 apud SEKI, 2000, p. 67).

Mesmo com a exemplificação por ela apresentada, Seki (2000, P. 67) afirma ainda que "em Kamaiurá os descritivos não detêm propriedades morfológicas e sintáticas específicas que justifiquem seu tratamento como uma classe separada 'adjetivos"”.

Além das terminologias, percebe-se nessas línguas interpretações e funcionamentos diferenciados para essa classe cujo objetivo é denotar qualidades em geral. Inclusive, ocorre também o compartilhamento de aspectos morfossintáticos com a classe dos verbos e dos nomes, no entanto, por não ser este o objetivo do trabalho, poderá ser melhor detalhado em outro momento. 


\section{OMNIPREDICATIDADE}

Este capítulo propõe demonstrar que, apesar de nome e verbo serem classes distintas e definidas em cada língua analisada a partir de critérios morfológicos, no plano sintático, a função básica do nome, de ser argumento, e a do verbo, de ser predicado, constitui relativa independência entre as classes lexicais e os constituintes sintáticos. Por essa razão, torna-se necessário discutirmos a omnipredicatividade como questão principal para a vocação predicativa ou não das entradas lexicais e a possibilidade de a função argumental ser derivada da função predicativa.

\subsection{O que é predicar?}

Antes de apresentar a discussão trazida por Launey (1986), faz-se necessário mencionar uma discussão ainda maior e anterior, provinda dos tempos de Platão e Aristóteles, que é a conceituação de predicado. Cavalcante Filho $(2013)^{16}$ relata que o primeiro trabalho da tradição ocidental a referir-se ao tema foi o Sofista, de Platão, no qual ele definia a predicação como uma conjunção de um sujeito e de um predicado. Nesse trabalho, o filósofo exibe, de forma sintética, uma perspectiva sobre o problema da linguagem que afetava os físicos e os sofistas: a relação entre a natureza (phýsis) e o costume (nómos), segundo a qual cada coisa é conhecida e designada.

Baseando-se nas contribuições de Platão, Bagno (2011) descreve que o filósofo propôs distinguir na sentença (logos) duas partes principais: ónoma e rhēma. Para Bagno essa divisão inicial é importante, porque revela, da parte do filósofo, uma lúcida percepção daquela que é a função quase única das línguas humanas: a predicação. O linguista afirma (BAGNO, 2011, p. 406):

Por mais simples ou mais complexo que seja um enunciado linguístico, por mais breve ou mais extenso, a operação primordial que se realiza nele é a predicação, ou seja, a expressão de um argumento e a atribuição de propriedades/qualidades/estados/ações a esse argumento.

\footnotetext{
${ }^{16}$ Francisco de Assis Vale Cavalcante Filho é doutor em Filosofia, defendeu a tese intitulada Os problemas da Opinião Falsa e da Predicação no diálogo Sofista de Platão. Atualmente leciona disciplinas de História da Filosofia Antiga no departamento de Filosofia da Universidade Federal da Paraíba.
} 
Percebe-se, portanto, que a atividade linguística se resume praticamente a predicar, e "predicar seria "falar de" e "dizer que": em Ivo nasceu, estou falando de Ivo e dizendo que ele nasceu" (BAGNO, 2011, p. 406).

A divisão entre ónoma e rhèma inicialmente não distinguia, como estudos linguísticos fazem atualmente, categorias lexicais. Por ser uma análise filosófica, interessada na natureza das palavras, e não na forma delas, a divisão platônica recobria simultaneamente, segundo Bagno (2011), essas duas maneiras de considerar os termos da sentença.

O que atualmente é chamado de adjetivo, para Platão, por exemplo, entrava na categoria do rhèma, do predicado, portanto do verbo. Bagno (2011) comenta que isso ocorre, primeiramente, porque o ato de predicar é exatamente o ato de atribuir qualidade/propriedade ao ónoma, ao nome/sujeito. E, em segundo lugar, porque todo adjetivo traz implícito um verbo, o verbo ser. No enunciado 'mulher encantadora, na verdade, refere-se a 'uma mulher [que é] encantadora'.

Um predicado, portanto, revela uma parte da constituição do ser de algo, ou seja, indica uma forma de que esse algo participa. Podemos dizer, então, que a determinação própria de um ser é resultado de suas relações de participação em outros seres, relações estas que se traduzem discursivamente como predicação.

\subsection{Discutindo sobre a omnipredicatividade}

Launey, entre suas pesquisas e investigações linguísticas, tornou-se referência nos estudos sobre a língua Nahuatl clássico, pertencente à família uto-asteca, usada pelos povos de mesmo nome e falada no território atualmente correspondente à região central do México, desde pelo menos o século VII.

Na língua Nahuatl, Launey (1986; 2004) observou que não haveria uma classe lexical extensa cuja vocação fosse a de ser argumento. Assim, a função predicativa não poderia ser considerada como um critério de demarcação entre as classes de nomes e verbos, bem como nas línguas da FLTG. Mostrou também que, nessa língua, categorias semânticas com manifestação morfológica explícita, como referencialidade-definitude ou aspecto-tempo, constituíam, em última instância, o núcleo duro dos critérios que permitiam identificar duas classes de raízes no léxico.

A partir desse padrão morfossintático observado em Nahuatl, Launey (1986) cunhou o termo omnipredicatividade, cuja consequência mais importante para línguas 
descritas apresentando esse padrão de organização é a não existência de uma verdadeira classe lexical com vocação à função argumental — esta é necessariamente derivada.

Launey (2004), durante seus estudos sobre o Nahuatl, fez a si mesmo a seguinte pergunta: afinal, essa língua é SVO, SOV ou VOS? No entanto, percebeu que estabelecer a ordem configuracional da língua não seria suficiente para explicar comportamentos sintáticos das classes de nomes e verbos. A seguir, exemplos do Nahuatl clássico ${ }^{17}$ propostos e analisados pelo linguista:

Ka $\quad \overline{1}$-ikniw in ki-nōca

ASSERT 3POS-friend DET 3OBJ-call

'Essa é a sua congénere que o chama' 18

(53) Mičin in $\mathrm{ki}-\mathrm{k}^{\mathrm{w}} \mathrm{a}$

Fish DET 3OBJ-eat

'Ele come peixe' 'O que ele come é peixe'19

Nos exemplos acima, apesar de ambos apresentarem nomes ('congénere' e 'peixe') e verbos ('chamar' e 'comer'), são os afixos atribuídos ou não a cada um deles que torna o exemplo (52) somo sendo de ordens sintáticas diferentes. O efeito de foco dado aos nomes seria uma primeira razão para justificar essa ocorrência de estruturas diferentes. $\mathrm{O}$ exemplo (53) não fala sobre o peixe, mas sobre o que um animal come, e diz que é peixe. Já no exemplo (52), o contexto diz que a serpente atrai codornas imitando o seu chamado, assim, o provável raciocínio da codorna seria "Tem um animal a me chamar, e eu posso dizer sobre ele que é da minha espécie" (LAUNEY, 2004, p. 1). Segundo Launey (2004), os nomes estão representando uma nova informação sobre algo dado como certo e expresso pela sequência in $V$. Desse modo, em ambas as frases, o nome seria o centro de informações, o foco, ou, na tradição europeia, o rema.

Launey (2004) demonstra que esse efeito remático ocorre porque as partículas de afirmação e, em alguns casos, explicação, $k a$, de interrogação, $k^{w} i \check{s}$, de opção, $m \bar{a}$, de hipótese, $\lambda \bar{a}$, de testemunho, kil, entre outras pertencem a um paradigma de marcadores aléticos, que não envolvem o controle humano. Estas podem ser combinadas com marcadores de outros paradigmas, nunca sendo usadas para formar uma frase por si só, mas podendo

\footnotetext{
${ }^{17}$ Os exemplos são apresentados tais como o foram pelo autor, no entanto, foram reenumerados.

${ }^{18}$ It is his congener that calls it'

${ }^{19}$ It eats fish' 'What it eats is fish'
} 
ocorrer na posição inicial da frase, antes de verbos, nomes e outros, como revelam os exemplos (LAUNEY, 2004, p. 4):

(54a) Ka ki-nōca'(O fato é que) ele o chama'20

(54b) $K^{w} i \check{s}$ ki-nōca? 'Será que ele realmente o chama?'21

(54c) Kil ki-nōca 'Diz-se que ele o chama'22, etc.

(55a) Ka $\bar{l}$-ikniw 'Ele/ela é (realmente) seu amigo',23

(55b) $K^{w} i$ is $\bar{l}$-ikniw? 'É realmente ele/ela seu amigo?'24

(55c) Kil $\bar{l}$-ikniw 'Diz-se que ele/ela é amigo' ${ }^{25}$, etc.

(56a) Ka Mešiko 'É (realmente) México,26

(56b) K $K^{w} i s ̌$ Meši $k o$ ? 'É realmente o México?'27

(56c) Kil Mešiko 'Diz-se que é o México'28, etc.

(57a) Ka mōs $\lambda a$ 'É (realmente) amanhã (ex. Que algum evento vai acontecer) ${ }^{, 29}$

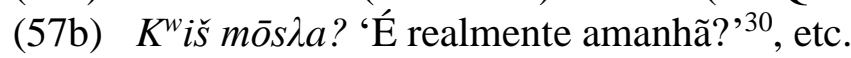

Para Launey (2004), não há nenhuma razão para postular uma regra pro-drop apenas para verbos, então admite-se que as mesmas propriedades predicativas são compartilhadas por verbos (54), nomes (55) e outros tipos de palavras, como topônimos (56) ou advérbios (57): todos representam noções previsíveis. Além disso, nomes e verbos podem tomar os mesmos prefixos pessoais de $1^{\mathrm{a}}$ e $2^{\mathrm{a}}$ pessoa.

Ni-k-nōca, ti-k-nōca 'Eu o chamo', 'Você o chama'31

$N-\bar{l}-i k n i w, t-\bar{l}-i k n i w$ 'Eu sou seu amigo', 'Você é seu amigo,32

Uma razão forte para rejeitar uma análise S-V ou O-V, por exemplo, para (52) e (53) é que o determinante in aparece diretamente antes do verbo (LAUNEY, 2004, p. 3), assim como, em outras frases mais prototípicas, podem aparecer antes do nome:

(60) Ka ki-nōca in ì-ikniw 'A sua congénere o chama'

(61) Ki- $k^{w}$ a in mičin 'Ele come o peixe' ${ }^{33}\left(K i-k^{w} a\right.$ mičin é possível, que significa 'Ele come peixe $^{34}$ )

\footnotetext{
20 '(The fact is that) he calls him'

21 'Does he really call him?'

22 'It is said that he calls him',

23 'It/he is (actually) his friend'

24 'Is it/he really his friend?'

${ }^{25}$ It is said that it/he is friend'

${ }^{26}$ It is (actually) Mexico'

${ }^{27}$ Is it really Mexico?

${ }^{28}$ It is said that it is Mexico'

${ }^{29}$ It is (actually) tomorrow (e.g. that some event will occur)

${ }^{30}$ Is it really tomorrow?

${ }^{31}$ I call him', 'you call him'

${ }^{32}$ I am his friend', 'you are his friend'

40
} 
Uma sequência sintática, segundo Launey (2004), Det $+\mathrm{N}$ pode ser uma frase nominal, mas uma sequência Det $+\mathrm{V}$ não é certamente uma frase verbal, uma vez que, normalmente, não são determinadas.

Admitindo uma mesma estrutura X para todas as frases de (54) a (57), sendo X qualquer classe de palavras, Launey (2004) supõe admitir de mesmo modo que (52) e (53) têm a mesma estrutura que (60) e (61), ou seja, X Det Y. Em (60) e (61), seria uma situação em que: $\mathrm{X}$ é um verbo, $\mathrm{Y}$ é um nome, e Det $\mathrm{Y}$ uma frase nominal que descreve o valor referencial de um argumento na posição do objeto. O linguista sugere manter a caracterização funcional desta última sequência (frase argumental em vez de frase nominal) e ver se ela se encaixa em casos como (52) e (53).

Como mencionado anteriormente, o exemplo (52), trazido por Launey (2004), não fala sobre o "seu congénere", mas sim sobre quem o chama. O linguista descreve a codorna pensando que há um conhecimento prévio de tal entidade, $\phi_{1}-k i_{2}-n \bar{o} c a_{3}$ 'he ${ }_{1}$ calls $\mathrm{s}_{3}$ it ${ }_{2}$ ', e uma informação, ou pelo menos uma opinião sobre essa entidade chamada, expressa por $\phi_{1^{-}}$ $\bar{\imath}_{2}$-ikniw 3 'it $t_{1}$ (is) its 2 congener ${ }_{3}$ ', tal como em (59), o mesmo predicado é aplicado a uma $1^{\mathrm{a}} \mathrm{e}$ $2^{\mathrm{a}}$ pessoa. Se o contexto é suficiente, $(\mathrm{Ka}) \phi-\bar{l}-i k n i w$ pode perfeitamente formar uma frase inteira, porque tem propriedades remáticas e uma estrutura de argumento totalmente desenvolvida. Assim, teríamos que admitir que, em (52), $\phi$-ī-ikniw é um nome predicativo, mas também que in ki-nōca descreve o valor referencial do sujeito de $\phi$-ī-ikniw, de modo que é o objeto do predicado nominal. Em outras palavras: em (52) o nome não é sujeito, mas predicado, e o sujeito é expresso por uma frase que tem como parte lexical um verbo.

Assim, a estrutura de (52) não é S-V, mas Pred-S e uma melhor tradução seria algo como 'Aquele que o chama é a sua congénere'. Pode-se postular a mesma estrutura para (53), em que o nome está em posição de predicado e $\mathrm{V}$ em uma frase sujeito ('O que ele come é peixe'). Launey (2004, p. 3) afirma ainda que essa estrutura geral Pred-S também é válida para frases mais prototípicas, como (60).

Predicados que não são verbos, como de (55) a (57), sem cópula, certamente são comuns entre as línguas do mundo. Incomum, porém, são frases argumentais contendo um verbo e construídos apenas da mesma forma, com o mesmo determinante, como sintagmas nominais. A partir dessa constatação, Launey (2004) segue sua análise fazendo testes com o inglês e o Nahuatl, podendo-se resumir os resultados na afirmação de cinco princípios para esta língua:

\footnotetext{
33 'It eats the fish'

34 'Its congener calls it'
} 
i) todos os itens lexicais podem ser usados como predicados;

ii) frases argumentais são predicados subordinados, que designam uma entidade, descrevendo o valor referencial de um termo;

iii) essa subordinação é possível se e somente se existir um coindexador entre um lugar argumental no predicado principal e no predicado subordinado;

iv) a previsibilidade é uma condição para a designação — você pode se referir a uma entidade como o peixe se e somente se é admitido anteriormente que é um peixe;

v) a tradução correta de um nome como mičin não é 'peixe', mas 'ser peixe', e uma frase como in mičin deve ser anotado como 'aquele que é o peixe'.

\subsubsection{As consequências inesperadas}

Launey (2004) chama de omnipredicativas línguas cuja morfossintaxe dá dicas não só para o princípio (i), apresentado acima, mas também para os princípios de (ii) a (v). Para esse padrão omnipredicativo, o linguista examina três consequências, apresentadas a seguir.

a) O parâmetro pro-drop é sem sentido.

A ideia do parâmetro pro-drop apareceu no início dos anos 80 para explicar línguas em que a posição de sujeito poderia ser deixada vazia de qualquer frase nominal ou pronome . Por exemplo, em espanhol tem-se tanto (62a) e (62b):

(62a) Su amigo llama 'Seu amigo está chamando'35

(62b) Llama 'Ele está chamando,36

As traduções em Nahuatl seriam (LAUNEY, 2004, p. 6):

(63a) Tē-nōca in $\bar{\imath}-i k n i w$

(63b) $T \bar{e}-n \bar{o} c a$

Launey (2004) sugere que Nahuatl seria uma língua pro-drop, como o espanhol. Mas, se $\bar{l}$-ikniw é um predicado subordinado, tem-se que reescrever (63a -b) como (64a-b):

\footnotetext{
${ }_{35}$ 'His friend is calling'

${ }^{36}$ 'He is calling'

42
} 
(64a) $\phi_{i}$-tēe-nōca in $\emptyset_{i}-\bar{l}-i k n i w$

(64b) $\phi-t \bar{e}-n \bar{o} c a$

Em seguida, $\phi_{i-\bar{l}-i k n i w}$ também é um predicado com uma frase de sujeito vazio. Lembrando que não há um $\mathrm{V}$ naturalmente predicativo e um $\mathrm{N}$ naturalmente designativo, mas dois predicados, $\phi-t \bar{e}-n \bar{o} c a$ e $\phi-\bar{l}-i k n i w$, cada um deles com sua própria estrutura argumental, cada um deles estando apto para formar uma frase por si só, e cada um deles estando apto a subordinar ou estar subordinado ao outro: a condição para que haja um coindexador de um lugar argumental em ambos. Assim, a fim de expressar o valor referencial de uma discussão, usa-se um predicado dos quais um argumento é coindexado ao argumento do predicado principal.

O que é problemático, segundo Launey (2004), não é a falta de expressão de sujeito em (63b), que representa a estrutura básica. Não se deve interpretar que (63a) se transforma em (63b), eliminando qualquer coisa, mas sim, começar a partir de (63b) e transformá-lo em (63a) por meio da adição de alguma coisa, porque, por algum motivo, é preciso expressar o valor referencial. Em outras palavras, não existe uma regra pro-drop, mas sim o que se pode chamar de uma regra NP-add, que funciona ao contrário.

b) Não há respostas elípticas.

Launey (2004) confirma que, pelas mesmas razões expostas acima, as respostas de uma só palavra também constituem frases de pleno direito, supondo que se tenha, em inglês, as seguintes respostas para as perguntas entre parênteses:

(65a) (O que ele faz com o peixe?) - Ele come ${ }^{37}$

(65b) (O que ele come?) - Peixe ${ }^{38}$

Não há nenhum problema quanto ao estatuto sentencial da resposta em (65a), mas a maioria das gramáticas, senão todas, serão relutantes em considerar a resposta em (65b) como uma sentença (LAUNEY, 2004, p. 5). Se perguntado a um linguista sobre o status gramatical de "peixe", nesse caso, a resposta provavelmente será: o peixe é o objeto NP em uma frase elíptica que pode ser restaurado como:

(65c) [Ele come] peixe ${ }^{39}$

\footnotetext{
${ }^{37}$ (What does it do with the fish?) - He eats it

${ }^{38}$ (What does it eat?) - Fish
} 
Não há nada do tipo em Nahuatl, onde as respostas são:

(66a) $K i-k^{w} a\left(=\phi-k i-k^{w} a\right)$

(66b) Mičin (=ф-mičin)

Em uma língua omnipredicativa, a resposta-palavra em (66b), como em (66a), é um predicado na $3^{a}$ pessoa do sujeito, que é remático (que representa uma informação) e saturado: o valor de seu único argumento é óbvio a partir do contexto de pergunta-resposta, 'a coisa de tal forma que (in) ele come $(O-k i-k w a)$ '. Portanto, segundo Launey (2004), não há necessidade de restaurar, como na interpretação mais comum para o inglês, algo como:

(66c) $\left[K i-k^{w} a\right]$ mičin

c) Não há movimentos-QU.

O mais forte desafio teórico da omnipredicatividade, para Launey (2004), diz respeito, provavelmente, ao estado da palavra interrogativa. Nos dados cedidos pelo linguista, encontram-se palavras escritas āquin para 'quem' e tlein para 'o que', em frases como:

(67a) Āquin tēnōtza? 'Quem está a chamar?'40

(67b) Tlein quicua? 'O que ele come?'41

Uma vez que exprime uma busca de informações, uma palavra QU-pergunta é, por definição, a parte remática da sentença que a contém. De acordo com essa análise, um script fonológico de (67a-b) não só irá usar símbolos únicos para cada fonema, mas também dividir as palavras interrogativas em dois elementos, como em (68a-b) (LAUNEY, 2004, p. 8):

(68a) $\bar{A} k$ in $t \bar{e}-n \bar{o} c a ?$

(68b) $\lambda e /$ in $k i-k^{w} a ?$

Contudo, não há necessidade de postular algo como um movimento-QU, como sugere Launey (2004), e extrair uma palavra interrogativa como 'quem' ou 'o que' fora de uma posição de sujeito ou objeto e movê-la para o início da frase. A realidade é que as

\footnotetext{
39 '[He eats] fish'

${ }^{40}$ 'Who is calling ?'

${ }^{41}$ 'What does he eat?'

44
} 
palavras interrogativas, como qualquer outra palavra da língua, são predicativas, mas elas têm uma peculiaridade: no caso de pares de predicados como tê-nōca 'chamar assim' ou $\bar{l}-i k n i w$ 'ser seu amigo' pode-se usar qualquer um deles como uma frase predicativa e a outra como frase de sujeito subordinado; entretanto, se um dos predicados é $\bar{a} k$ 'ser quem' ou $\lambda e / /$ 'ser o que', que são necessariamente remáticos, a única possibilidade é usá-los como frase predicativas, como (68a-b), e (69a-b), que são agramaticais:

(69a) *Té-nōca in $\bar{a} k$

(69b) *Ki-k $k^{w}$ in $\lambda e /$

Para Launey (2004), não há nenhum estágio na derivação de (68a-b), em que $\bar{a} k$ '(ser) quem' e $\lambda e^{\prime}$ '(ser) o que' seria, respectivamente, objeto de nōca 'call' e objeto de $k^{w} a$ 'comer'. O que acontece é que eles são necessariamente predicados, e que o seguinte na sentença X é a frase argumental desses predicados. Então, é possível reescrever novamente essas frases como (70a-b) e parafraseá-las como (71a-b):

(70a) $\phi_{i}-\bar{a} k$ in $\emptyset_{i}-t \bar{e}-n \bar{o} c a ?$ 'Aquele que ele chama é quem?'42

(70b) $\phi_{i}$ - $\lambda e / i n \phi_{i^{-}} k i-k^{w} a$ ? 'Aquilo que ele come é o quê?'43

Além do Nahuatl clássico, outras línguas, independentes geneticamente, tais como as línguas Salish e as línguas filipinas têm sido descritas como línguas omnipredicativas. Para algumas das línguas da FLTG, estudos linguísticos também indicam este padrão omnipredicativo, consequentemente, a função argumental é derivada da predicativa (QUEIXALÓS, 2001). Seguindo este raciocínio, a função predicativa não necessitaria de morfologia para ser expressa, já que o item lexical é gerado no léxico como predicado, ou seja, a função é imanente a ele. Entretanto, a função argumental necessitaria de material gramatical complementar para ser expressa, sendo, então, o sufixo - $a$. Naturalmente, esta é secundária em relação à função predicativa.

Para Queixalós (2001), o grau de omnipredicatividade em línguas da FLTG é variável e parece ser possível relacionar maior ou menor omnipredicatividade à maior ou

\footnotetext{
${ }^{42}$ 'The one such he calls is who?'

${ }^{43}$ 'The thing such that he eats it is what?'
} 
menor produtividade do sufixo - $a$, cuja função parece ir além da de atribuir referência a temas predicativos, designando entidades e, por conseguinte, a de ser argumento. 


\section{4}

\section{A FUNCIONALIDADE DO -A}

A discussão acerca do sufixo - $a$ está relacionada à maneira como os nomes, quando não especificados por esse morfema, funcionam como predicado ou vocativo, e os verbos, quando especificados por esse morfema, funcionam como argumento. Essa situação implica uma relativa independência entre as classes nomes e verbos e os constituintes sintáticos argumento e predicado.

Serão analisadas, a seguir, as descrições sobre o sufixo - $a$ empreendidas por cada pesquisador nas línguas da FLTG estudadas nessa pesquisa, pontos relevantes que diferem ou assemelham a funcionalidade do sufixo nessas línguas e, de forma breve, a ocorrência do - $a$ em outras línguas da FLTG.

\subsection{Breve histórico do sufixo $-a$}

Segundo Queixalós (2006), dentro do padrão omnipredicativo, há uma notável uniformidade interlinguística na classe das designações: estas são geralmente compostas de elementos de base dêitica e, às vezes, de nomes. O maior grau de omnipredicatividade de uma língua se revela na exiguidade da classe das designações. O Tupí-Guaraní teria um grau de omnipredicatividade forte, comparável ao do Nahuatl: sua classe de designações se reduz a alguns dêiticos. Assim, a omnipredicatividade forte não pode ser atribuída ao Tupí-Guaraní como família linguística, porque as línguas descritas nesta pesquisa apresentam graus variados de exiguidade da classe das designações.

Conforme Queixalós (2006, p. 267):

Em seu estudo de 1999, Jersen afirma que, no proto-Tupí-Guaraní, o nome pode atuar como predicado, tomando-se a ausência de -a como a única pista da derivação. Em seu trabalho de 1998, Jersen afirma que, em Kayabi, o -a se espalhou para raízes que terminam em uma vogal. A mesma autora retoma o espírito dessa declaração em sua obra de 1999, na qual ela menciona a extensão desse morfema a todos os nomes em Assurini Tocantins ${ }^{44}$.

Queixalós (2006) assume que, ao contrário, esse sufixo nunca se propagou de um contexto a outro, e sim que ele era onipresente em uma época dada e, desde então, só fez

\footnotetext{
44 Tradução livre do original: "In his 1999 study, Jersen states that in proto-Tupi-Gurani the noun can fuction as a predicate, taking as the only clue of the derivation the absence of $-a$. In his 1998 work, Jersen states that in Kayabi the $-a$ has spread to roots ending in a vowel. The same writer takes up again the spirit of this statement in his 1999 work, in which she mentions the extension of this morpheme to all the nouns in Tocantins Assurini".
} 
regredir até desaparecer totalmente em algumas línguas - o linguista chama essa época de estágio inicial. Cabral (2001 apud QUEIXALÓS, 2006) demonstra que o sufixo já estava presente no proto-Tupí-Guaraní. O mesma autora traz à tona fortes indícios de que o que Queixalós chamou de estágio inicial se situaria além do proto-Tupí-Guaraní.

Sobre a pronúncia (articulação lenta ou rápida, gerações coexistentes no tempo, testemunhos com alguns decênios ou séculos de distância, variedades próximas de uma mesma língua), as observações relatadas no trabalho de Cabral (2001), supracitado, são eloquentes a respeito do sentido da evolução e indicam que, em certos casos, essa evolução está acontecendo sob nossos olhos. Pode ser apresentada como exemplo a variedade Wayampi, visitada por Coudreau no fim do século XIX, que tinha ainda o sufixo - a bem presente e, atualmente, não mais o possui.

Para esse estágio inicial, sugerido por Queixalós (2006, p. 268), o linguista apresenta as seguintes caraterísticas:

i) como propriedade básica, todas ou quase todas as raízes lexicais são predicativas;

ii) o sufixo - $a$ deriva designações a partir dessas raízes;

iii) existe uma pequena classe lexical de designações e ela nunca se combina com o sufixo $-a$

iv) todo o constituinte nas funções de: predicado equativo, sujeito, objeto, complemento adnominal, complemento circunstancial e que não pertencer à classe de designações, ocorre obrigatoriamente combinado com o sufixo $-a$.

As línguas documentadas são testemunhas dos estágios diferentes que a fragmentação do sistema inicial tem atingido. Cada lacuna na suposta distribuição inicial do sufixo - $a$ deve ser vista como sintoma de um único e mesmo processo: a perda da omnipredicatividade como princípio básico de organização do sistema gramatical. Queixalós (2006, p. 269) discute que é importante distinguir dois fatores independentes de evolução que, de certa forma, se conjugam para produzir o mesmo resultado. O primeiro é estritamente gramatical: a perda da omnipredicatividade acarreta a perda de funcionalidade do sufixo $-a$, fazendo com que ele suma ou perca seu estatuto de morfema. O segundo ultrapassa os limites da gramática: pela sua posição na palavra e pela sua constituição fonológica, o sufixo - $a$ seria fraco e seu desgaste fonológico acabaria facilmente com sua existência. Naturalmente, ele só deixa de existir fonologicamente, porque o seu papel gramatical se tornou obsoleto. 
Alguns desses fatores de evolução sobre o funcionamento do sufixo - $a$ em línguas da FLTG, tanto gramaticais quanto fonológicos, serão mais bem discutidos no próximo capítulo, que também inclui apresentação dos dados das línguas propostas para esta pesquisa.

\subsection{O sufixo -a em línguas da FLTG}

Na literatura da família Tupí-Guaraní, ele vem recebendo diversas denominações, tais como: índice nominal (Rodrigues, 1953; Lemos Barbosa, 1956), caso nominal (Rodrigues, 1981; Jensen, 1989), nominalizador (Almeida; Irmãzinhas de Jesus Paul, 1983; Vieira, 1993), caso argumentativo (Rodrigues, 1996, 2001; Praça, 1999); caso nuclear (Seki, 2000; Borges, 2006) e morfema referenciante (Queixalós, 2006).

(PRAÇA, 2007, p. 41)

Além de receber terminologias variadas, o sufixo - $a$ é analisado de maneiras diferentes quanto ao seu funcionamento.

\subsubsection{No Tapirapé}

Em Tapirapé, o sufixo - $a$ pertence ao que que Praça (2007) chamou de "morfologia transcategorial" da língua Tapirapé, isso por ele ser onipresente em diferentes tipos de constituintes, principalmente naqueles compostos de nomes e verbos, mas também pode aparecer nos constituídos de posposições e advérbios.

De acordo com os dados apresentados por Praça (2007), qualquer item lexical, tanto nomes quanto verbos, pode exercer as funções sintáticas de predicado ou de argumento, além de compartilhar outras similaridades morfossintáticas:

(71) marare- $\varnothing \quad$ i-memyr

vaca-X 3.II.filho

'a vaca tem filhote (lit. 'a vaca filhote dela (existe)')'

(72) xãwar

cachorro

'é cachorro' 
Em (71) e (72), percebe-se que, em Tapirapé, qualquer item lexical que possa ser identificado como nome com base em suas características semânticas prototípicas, como ser entidade, ter configuração espacial e estabilidade corporal (GIVÓN, 2001), pode instituir núcleo de predicado sem que haja cópula ou morfologia que indique mudança de classe gramatical.

Por sua vez, o mesmo nome pode servir de argumento. Para isso, precisa receber o - $a(-\mathrm{a} \sim-\varnothing)$ :

i-memyr-a a-xaj'a

3.II-filho-X 3.I.chorar

'o filho dela chorou'

(74)

$\begin{array}{lll}\text { xe=r-opy- } \varnothing & \text { a-xokã } & \text { xãwãr-a } \\ \text { 1sg.II=R-pai-X } & \text { 3.I.matar } & \text { cachorro-X } \\ \text { 'meu pai matou um cachorro' } & \end{array}$

No exemplo (71), memyr 'filho do ego feminino' é núcleo de predicado existencial possessivo e, em (73), é utilizado como sujeito. Em (72), xãwãr 'cachorro' é um predicado existencial 'absoluto' (PRAÇA, 1999), enquanto, em (74), é usado como objeto.

Já em (75) e (76), percebe-se que, em Tapirapé, os temas identificados com características semânticas prototípicas de verbos, como ter instabilidade temporal e não inscrição no espaço (GIVÓN, 2001), ou seja, descrevendo acontecimentos, são predicados:
(75) a-hyj
3.I-correu
'ele corre'

\begin{tabular}{|c|c|c|c|}
\hline ka'i- $\varnothing$ & a-ka-wo & 'ywyrã- $\varnothing$ & r-e \\
\hline macaco-X 3.I-falar & 3.III-estar-GER & árvore-X & R-POS \\
\hline
\end{tabular}

Entretanto, de maneira similar ao nome, ao receberem o sufixo - $a$, os temas identificados com características semânticas prototípicas de verbos funcionam como argumento: 
ne= $\varnothing-$ hyj-a i-kãto

2sg.II=R-correr-X 3.II-ser.bom

'sua corrida foi boa'

$(78)$

ã-inow $\quad$ i-xe'eg-a
1sg.I-ouvir $\quad$ 3.II-falar-X
'eu escuto a fala dela'

Nos exemplos acima, como se pode observar, os "verbos" prototípicos (75) hyj ‘correr' e (76) xe'eg ‘falar’ são utilizados como núcleos de predicado. Já em (77) e (78), são empregados como argumentos, sendo que em (77) hyj é sujeito e em (78)xe'eg é objeto.

Praça (2007, p. 40) afirma que o alomorfe (-a) varia em [ã] e [a]. Sendo que, na fala dos mais velhos, observa-se uma maior ocorrência da variedade [ã] e, na fala dos mais jovens, ocorre a variante [a], que em determinadas falas é quase inaudível. Foneticamente, esse morfema ocorre nos seguintes contextos: o alomorfe $(-a)$, em temas terminados em consoantes (79) e o alomorfe $(-\varnothing)$, em temas terminados em vogal (80):

$$
\begin{array}{ll}
\text { t-amõj-a } & \text { a-ãpa o’yw-a } \\
\text { 3.II-avô-X } & \text { 3.I-fazer flecha-X }
\end{array}
$$

'o avô dele fez flecha'

$\begin{array}{llll}\text { ’ãwãxi- } \varnothing \quad \text { mĩ } & \text { a-kytyk } \quad \text { xe= } \varnothing-y-\varnothing \\ \text { Milho-X } & & \text { HAB } & \text { 3.I-ralar } \quad \text { 1sg.II=R-mãe-X }\end{array}$

'minha mãe sempre rala milho'

Nomes — incluindo nomes próprios —, verbos e, também, as classes fechadas de pronomes e demonstrativos podem receber esse morfema. Os nomes marcados com - $a$, portanto, ocorrem como: sujeito e objeto de verbos transitivos (81); argumento único de intransitivos (82) e (83); complemento de posposição (84); e em orações nominais equativas/inclusivas (85):

(81) xãwãr-a a-o’o konomĩ-

cachorro-X 3.I-morder menino-X

'o cachorro mordeu o menino' 
(82)

miãr-a mĩ a-yj kã'ã-pe

veado-X HAB 3.I-correr mata-LOC

'o veado sempre corre na mata'

(83) $\quad$ xe $=\varnothing$-memyr-a i-xinyk

1sg.II=R-filho-X 3-ser.triste

'meu filho está triste'

(84) i-men-a $\quad$ xe=r-ãpe- $\varnothing \quad$ r-opi a-a

3.II-marido-X 1sg.II=R-caminho-X R-POS 3.I-ir

'o marido dela vai no meu caminho'

(85) $\quad$ xe=Ø-kywyr-a kãpitãw-a

1 sg.II=R=irmão- $X$ capitão- $X$

'meu irmão é capitão (cacique)'

Os verbos, por sua vez, podem receber o sufixo $-a$ nos seguintes ambientes sintáticos: argumento único de verbo descritivo e objeto de transitivo, como em (86) e (87):

$\begin{array}{lll}\text { xe=Ø-xe'eg-a } & \text { mĩ } & \text { i-ãrõãrõ } \\ \text { 1sg.II=R-falar-X } & \text { HAB } & \text { 3.II-ser.bonito }\end{array}$

'minha fala sempre é bonita'

(87) ie-Ø ã-ixã-matar ne=Ø-porããj-a

1sg-X 1sg.I-ver-querer 2sg.II=R-dançar-X

'eu quero ver sua dança'

Em Tapirapé, nomes próprios em função vocativa, ou seja, fora do contexto sintático não recebem o sufixo - $a$, como no exemplo (88), citado por Praça (2007, p. 43).

(88) kãtowyg e-xar ãpy

Kãtowyg 2sg.IMP-vir antes

'Kãtowtg, venha, por favor' 
$\mathrm{Na}$ descrição da funcionalidade do sufixo - $a$ para a relação predicado e argumento, Praça (2007, p. 43) afirma que:

o morfema $\{$-a $\}$ age no campo sintático. A ocorrência deste sufixo em itens lexicais plenos, como nomes e verbos, bem como em demonstrativos, pronomes e nomes próprios, assinala uma derivação de função sintática. Entretanto, pode-se considera-la como uma função secundária à de construir referência em raízes de natureza predicativa, pois, ao se tornar capaz de referir, um item lexical nominal ou verbal torna-se disponível à função argumental.

Em Tapirapé, o nome tem maior ocorrência como núcleo de argumento que como predicado; e o verbo, por sua vez, tem maior ocorrência como núcleo de predicado que como argumento. Apesar disso, observa-se o mesmo comportamento morfossintático entre eles ao instituírem as funções de predicado e argumento. A função predicativa não é marcada e a função argumentativa é assinalada pelo sufixo - $a$. Assim sendo, o sufixo - $a$, denominado referenciante por Queixalós (2006) e adotado por Praça (2007), constrói designações a partir de raízes lexicais predicativas, já que enquanto predicado tais raízes não remetem a nenhuma entidade.

\subsubsection{No Kamaiurá}

No Kamaiurá, o sufixo - a pertence ao que Seki (2000, p. 106) chamou de "fenômenos relacionados a subconstituintes da oração", como exposto abaixo (SEKI, 2000, p. 107):

Ao figurarem como elementos de construções sintáticas, os nomes (e seus equivalentes sintáticos) vêm acompanhados de diferentes sufixos, mutuamente exclusivos, que ocorrem como elementos terminais da palavra gramatical, assinalando distintos papéis sintático-semânticos dos nomes nas construções. Esses sufixos são interpretados como constituindo um sistema de flexão casual (...).

Em Kamaiurá, para a marcação de caso, são três termos marcados — nuclear \{a\}, locativo $\{$-ip $\}$ e atributivo $\{$-ram $\}-$ e um não marcado - Ø. Os nomes marcados com os diferentes sufixos casuais podem ocorrer como predicado; os nomes no caso não marcado (ausência do sufixo - $a$ e demais sufixos) são usados como vocativos, constituintes deslocados e também como forma citacional, correspondendo, nesta última situação, a predicados que identificam objetos no mundo. 
O sufixo - $a$, no Kamaiurá (SEKI, 2000), opera em diferentes níveis sintáticos, relacionando o nome a outro elemento da locução, ou ao predicado, na oração: "O sufixo de caso 'nuclear' tem também a função de indexar, isto é, de identificar o radical como nome" (SEKI, 2000, p. 107). É usado para marcar funções tipicamente nominais, como: sujeito de predicados verbais e não verbais (89), (90) e (91); objeto de verbos e posposições (92) e (93); modificador (possuidor) na locução genitiva (94); complemento de cópula (95); predicado nominal (96); e um nome núcleo modificado por outro nome não possuível, ou possuído prefixado com marcador de possuidor indefinido de terceira pessoa (97) e (98):

(89) kunu'um-a tete rak o-ho ko'yt

menino-X somente At 3-ir FS

'somente o menino foi'

(90) i-'ajur-a i-huku

3-pescoço-X 3-comprido

'o pescoço dele é comprido'

(91) pe-a morerekwat

aquele-X chefe

'aquele é chefe'

(92) kunu'um-a h-uwaj-a w-ekyj

menino-X 3-rabo-X 3-puxar

'o menino está puxando o rabo dele'

(93) je=r-uw-a nite

$1 \mathrm{sg}=$ Rel-pai-X com

'com meu pai'

(94) jawar-a r-a'yt

onça-XRel-filho

'filho(te) de onça'

(95) kara'iw-a pe-ko

não-índio-X 2pl-Cóp

'vocês são não-índios' 
(96)

waniwani-a $=$ te $=j e=$ 'na $\quad$ i-'atywahaw-a ko=wa

N.pr.-X=F=Rep=Próx3-primo-X $\quad F S=M S$

'waniwani era o primo dele'

(97) jawar-a kujã

onça-Xmulher

'onça fêmea'

(98) jawar-a t-a'yt

onça-X3-filho(te)

'a onça tem filhote'

Seki (2001, p. 56) indica que uma característica do sufixo - $a$ é que ele é usado para marcar nominais em função de sujeito de transitivos e intransitivos e também em função de objeto. Essas funções se distinguem por outros meios, como a ordem e a presença de distintas séries de elementos pronominais no verbo.

$\mathrm{Na}$ fala, principalmente rápida, o sufixo não se realiza foneticamente, quando acrescentado a radicais terminados em 'a' tônico e quando é imediatamente seguido por palavras iniciadas em vogal átona:
(99) ywyrá (-a) o-kaj
árvore-X 3-queimar
'a árvore está queimando'
(100) jawár (-a) o-juka
onça-X3-matar
'ele matou a onça'

\subsubsection{No Guajá}

No Guajá, de acordo com Magalhães (2007, p. 141), o sufixo - a ocorre em nomes com função de sujeito de predicados verbais (101), adjetivais (102) ou nominais (primeiro nome do 103) e objeto de predicados verbais (104). Ocorre também em nomes que apenas se referem aos argumentos nucleares, mas que exercem funções não argumentais, como aqueles em que o sufixo - $a$ aparece afixado a um sintagma nominal externo, isto é, 
deslocado da oração (105), em nomes com função de aposto explicativo (106) e em nomes com função de núcleos de predicados equativos (segundo nome do exemplo 103):

(101) tapi'ír-a $\quad$-wyhý ahá ka’á r-ipí

anta-X 3-correr CTF mato $\mathrm{R}^{1}$-por

'a anta corre (indo) pelo mato'

(102) i-mymýr-a h-ahý

$\mathrm{R}^{1}$-filho-X $\quad \mathrm{R}^{2}$-doente

'o filho dela está doente'

(103) Itaxĩ-a pĩ=Ø-tamỹ-a?

Itaxĩ-X $\quad 23=\mathrm{R}^{1}$-chefe-N

'Itaxĩ é (o) chefe de vocês?'

(104) jahá akwixí-a a-xá

eu cotia-X 1-ver

'eu vi a cotia'

(105) a'é $\varnothing$-wehẽ, há=Ø-mymýr-a

DEM 3-nascer $\quad 1=\mathrm{R}^{1}$-filho-X

'ele nasceu, o meu filho'

(106) Xa'ahõxiká Ø-mỹ n-imá- $\varnothing, \quad$ kaí-a, karaí-a $\varnothing$-xá

Xa'ahõxiká $\quad \mathrm{R}^{1}$-antiga $\quad \mathrm{R}^{1}$-animal.de.criação-X macaco-prego-X não.índio-X 3ver

'o bicho de estimação da falecida/antiga Xa'ahõxiká, um macaco-prego, viu o nãoíndio'

O alomorfe $-\varnothing$ ocorre em temas terminados por vogal central baixa oral ou nasal e o alomorfe - $a$ em temas terminados por consoante ou por outras vogais.

(107) amã- $\varnothing \quad$ ha=Ø-pí

zangão-X $1=\mathrm{R}^{1}$-picar

'o zangão me picou'

(108) jakaré-a pirá- $\varnothing \quad$ u-'ú 
jacaré-X peixe-X 3-comer

'o jacaré comeu o peixe'

Magalhães (2007) afirma que é comum que, em fala rápida, o sufixo - a não se realize foneticamente quando o tema por ele flexionado é seguido por uma vogal átona inicial, como em ka'l' 'macaco-prego' no exemplo a seguir:

(109) ka'í(-a) inajã- $\varnothing \quad$ u-’ú iká waté

(macaco.prego-X inajá-X 3-comer POS1 no.alto)

'o macaco-prego comia inajá no alto'

O sufixo - $a$ não marca os argumentos circunstanciais, ou seja, os nomes que ocorrem como determinantes num sintagma posposicional (110) ou num sintagma genitivo (111):

(110) a-n-ehẽ wý r-iá

(1-CAUS.COM-sair terra $\mathrm{R}^{1}$-de)

'tirei da terra'

(111) ka’í Ø-pó-a

(macaco-prego $\quad \mathrm{R}^{1}$-mão-X)

'a mão do macaco-prego'

Com exceção dos determinantes de sintagmas posposicionais e genitivos citados acima, os temas nominais não marcados com o sufixo - $a$ constituem predicados existenciais:

(112) tapi'í ka’á-pe

(anta mato-LOC)

'tem anta no mato' (lit. 'anta (existe) no mato')

(113) i-ký

( $\mathrm{R}^{2}$-piolho)

'(ele) tem piolho' (lit. 'piolho dele (existe)') 


\subsection{As orações equativas}

Segundo Praça (2007), as orações equativas/inclusivas do Tapirapé têm estrutura sintática diferente das demais orações, uma vez que têm um nome marcado com o sufixo - $a$ como predicado ((114) equativa e (115) inclusiva).

(114) xywãeri-Ø kãpitãw-a

Xywãeri-X capitão-X

'Xywãeri é o cacique (capitão)'

(115) ãrãr-a koxỹ-Ø r-eymãw-a

arara-X mulher-X $\quad \mathrm{R}$-animal.doméstico-X

'arara é animal doméstico da mulher'

O mesmo fenômeno percebe-se também no Guajá, ou seja, os nomes também podem ocorrer como predicados em construções equativas recebendo o sufixo - $a$ :
(116) karaí-a jahá
não-índio-X eu
'eu sou não-índio'

Segundo Seki (2000), o núcleo do predicado das equativas no Kamaiurá também recebe o sufixo - $a$. Assim "o nominal predicado é fonologicamente marcado pelo deslocamento do acento do radical para o sufixo de caso" (SEKI, 2000, p. 161):

(117) je=Ø-tutyt-a morerekwar-á

$1 \mathrm{sg}=$ Rel-tio- $\mathrm{X}$ chefe- $\mathrm{N}$

'meu tio é o chefe'

Contudo, no Kamaiurá, os núcleos do predicado nominal das orações classificadoras não recebem o referido morfema e "identificam o referente do nominal sujeito como pertencente à classe designada pelo nominal predicado" (SEKI, 2000, p. 162):

(118) je=Ø-tuty-a Morerekwat

$1 \mathrm{sg}=$ Rel-tio- $X \quad$ chefe

'meu tio é chefe' 
A presença ou a ausência do sufixo - $a$ no predicado faz a diferença entre dois tipos de predicação. A função básica dessa marca, portanto, não pode ser a de transformar um predicado em argumento, ou seja, a de subordinar um predicado a outro predicado (QUEIXALÓS, 2006). A diferença entre as estruturas (117) e (118) reside nas propriedades do termo predicativo em relação à referência: 'chefe' em (118) não refere, pois ele não remete a nenhuma entidade dada como existente; ele só remete a uma classe de elementos definida, em compreensão, por uma determinada propriedade, "ser chefe".

A relação entre o sujeito e o predicado em (118) é inclusiva, o que equivale dizer que o referente do sujeito se identifica a um elemento qualquer da classe delimitada pela expressão em função de predicado. Por sua vez, 'chefe'- $a$ em (117) refere de fato: ele remete a uma classe definida extensionalmente pelo seu elemento único, dado como entidade existente e individualmente identificável. Em (117), a relação entre o sujeito e o predicado é equativa: o referente do sujeito se identifica ao elemento único da classe delimitada pela expressão em função de predicado.

Percebe-se, portanto, que o predicado das orações equativas/inclusivas no Tapirapé e no Guajá se assemelham por terem o sufixo - $a$, talvez ligado ao que Queixalós (2006) chamou de referenciação. Já no Kamaiurá, o nome está na função de predicado, sem o sufixo $-a$.

\subsection{Nomes próprios, demonstrativos e pronomes}

Segundo Queixalós (2001), o sufixo - $a$ institui uma expressão capaz de construir referência em temas que, por si só, não são capazes de referir, por serem primariamente predicado. Assim sendo, o - $a$ construiria designações a partir de raízes lexicais predicativas, já que enquanto predicado tais raízes não remetem a nenhuma entidade. Essa análise seria conveniente se o sufixo - $a$ fosse apenas marcado em nomes e verbos, no entanto observam-se dados como os seguintes no Tapirapé (119), no Guajá (120) e no Kamaiurá (121):

$\begin{array}{lllll}\text { kãtowyg-a } & \text { rãka } & \text { a-mor } & \text { xe=Ø-we } & \text { mayg-a } \\ \text { Kãtowyga-X } & \text { PAS.REC } & \text { 3.I-dar } & \text { 1sg.II=R-POS } & \text { remédio-X } \\ \text { 'foi Kãtowyga que me deu remédio' } & & \end{array}$


(120)

o-hó Kamairú-a

3-ir Kamairú-X

'Kamairú foi embora?'

(121)
waniwani- $\mathrm{a}=\mathrm{te}=\mathrm{je}=$ 'na
i-'atywahaw-a
ko=wa
N.pr.-X=F=Rep=Próx3-primo- $\mathrm{X} \quad \mathrm{FS}=\mathrm{MS}$
'waniwani era o primo dele'

Nos exemplos (119), (120) e (121), percebe-se o sufixo -a marcando nomes próprios. Nos exemplos seguintes, (122) e $(123)^{45}$, a marcação ocorre em demonstrativos do Tapirapé e do Guajá, respectivamente:
ã'ẽ $=g a ̃-e ' y m-a$
mĩ a-enow
ne= $\varnothing$-mãrãkã- $\varnothing$
$\mathrm{DEM}=\mathrm{SG}-\mathrm{NEG}-\mathrm{X}$
HAB 3.I-escutar
2sg.II=R-cantar-X

'não é ele que sempre escuta seu canto'

(123)

$\begin{array}{llll}\text { i-puhú-a } & \text { papé } & \varnothing \text {-japó-há- } & \text { kú-a } \\ \text { R-novo-X } & \text { papel } & \text { R-fazer-NZR-X } & \text { aqui (sem.movimento)-X }\end{array}$

'este lápis é novo'

Ainda no Tapirapé, percebe-se o sufixo - $a$ podendo marcar também pronomes (124), comportamento não possível no Guajá:
(124)
ie-e’ym-a kwee ã-tym 'ãwãxi- $\varnothing \quad$ ka-pe
1sg-NEG-X PAS.MED 1sg.I-plantar milho-X
roça-LOC
'não fui eu quem plantou milho na roça'

No entanto, no Guajá, os pronomes independentes terminam em -á, o que pode ser interpretado como um indício de que houve um sufixo - $a$ ali e que se gramaticalizou.

Como explicar a marcação em nomes próprios, demonstrativos e pronomes, que são expressões referenciantes por natureza? Esse fato difere essas línguas daquelas que também apresentam um comportamento omnipredicativo, em que as designações não recebem morfemas cuja função seja a de ser capaz de referir.

\footnotetext{
${ }^{45}$ De acordo com Magalhães (2007, p. 69) o demonstrativo kó 'aqui', ao receber o sufixo -a, muda para kú-a e significa 'este', o demonstrativo kwý 'aí', muda para kwí-a e significa 'esse' e kwáe 'lá' muda para kwáj-a e significa 'aquele'.

60
} 
Quanto aos nomes próprios em função vocativa, ou seja, fora do contexto sintático, no Tapirapé, no Guajá e no Kamaiurá, não haverá marcação com o sufixo - $a$. Praça (2007, p. 43) sugere essa ocorrência por ser o vocativo "uma das manifestações por excelência da função conativa da linguagem. O falante, neste caso, está interessado em envolver o ouvinte, diretamente, no processo comunicativo". Como pode ser atestado nos exemplos do Guajá, (125), e do Tapirapé, (126).

(125) Jamakwaré, mõ po-hó tá mĩ-pe Jamakwaré INT 23-ir PROJ para.onde

'Jamakwaré, para onde vocês estão indo?'

(126)

$\begin{array}{lcc}\text { kãtowyg } & \text { e-xar } & \text { ãpy } \\ \text { Kãtowyg } & \text { 2sg.IMP-vir antes } \\ \text { 'Kãtowyg, venha, por favor' }\end{array}$

\subsection{O sufixo - a em outras línguas da FLTG}

O Tupinambá é uma língua indígena da família linguística Tupí-Guaraní, falada em grande parte da costa atlântica do Brasil, a qual foi amplamente documentada nos séculos XVI e XVII, mas que foi deixando de ser falada, principalmente devido ao extermínio de sua população, num processo que praticamente se concluiu na primeira metade do século XVIII. Nessa língua, o sufixo - a se mostrava bastante produtivo, sendo chamado de caso argumentativo por Rodrigues (1996).

Rodrigues, ao descrever a língua Tupinambá, referiu-se a esse morfema como “caso argumentativo" (RODRIGUES, 1996), interpretando-o como parte de um paradigma casual junto com os casos locativos pontual, locativo difuso, locativo situacional e translativo. O autor descreveu a função do sufixo - $a$ no Tupinambá e dos casos em geral.

No Tupinambá, os nomes podiam receber o sufixo - a compreendendo todas as principais funções gramaticais, como as de sujeito de verbos intransitivos e transitivos, de objeto direto, de possuidor e de objeto de posposição (RODRIGUES, 1996). Os exemplos abaixo ilustram alguns desses casos na língua:

$$
\begin{array}{ll}
\text { tapiPír-a o-só } & \text { ók-a } \varnothing \text {-koti } \\
\text { vaca-X3SUJ-ir } & \text { casa-X } \quad \text { CONT-para.o.lado.de }
\end{array}
$$

'as vacas foram para a banda das casas' 
(128)

sjé $\quad r$-úß-a t-oßajár-a já-Ø-Pú

eu CONT-pai-X HUM-adversário-X 3SUJ-3OBJ-comer

'os contrários comeram meu pai'

$(129)$

kwesé pajé-Ø maPéasißór-a $\varnothing$-sußán-i

ontem pajé-X o.doente-X CONT-chupar.ritualmente-CIRC

'ontem o feiticeiro chupou ao enfermo'

(130) aßá- $\varnothing$ pe erima?é ikó Pár-a o-j-moján

pessoa-X INT antigamente este mundo-X 3SUJ-3OBJ-fazer

'quem antigamente fez este mundo?

(131)

o-si- $\varnothing \quad$ Ø-posépitán-a $\quad r-u ́(\beta)-i$

3COR-mãe-X CONT-deitado.com.criança-X CONT-estar.deitado-CIRC

'com sua mãe está deitada a criança'

Segundo Rodrigues (1996, p. 61-62), os nomes possuíveis ${ }^{46}$, sem os sufixos casuais, podem ser núcleos de predicados possessivos, os quais apresentam o mesmo comportamento gramatical que os predicados que têm por núcleos os verbos intransitivos, (132) a (133). Ou seja, nessa língua, um predicado intransitivo pode ter por núcleo tanto um verbo intransitivo, quanto um nome possuível sem marcadores casuais.

(132) né r-ér

você CONT-nome

'você tem nome'

(133) na né r-ér-i

não você CONT-nome-NEG

'você não tem nome'

(134) né r-ér-eme

você CONT.-nome-SUBJ

'se/quando você tiver nome'

(135) né r-ér-e?í-me

46 "São os que denominam partes de um todo, atributos e membros de um sistema de relações, bem como os artefatos humanos, aí incluídas as plantas cultivadas" (RODRIGUES, 1996, p. 61). Rodrigues (1996) também considera os nomes de qualidades e estados como nomes possuíveis. 


\section{você CONT.-nome-NEG-SUBJ}

'se/quando você não tiver nome'

Por outro lado, todos os verbos do Tupinambá, tanto intransitivos como transitivos, podem ser usados como argumentos, ou seja, como núcleos de sintagmas nominais. Nessa situação, Rodrigues (1996) indica que eles se comportam como nomes possuíveis e recebem marcadores de caso. Enquanto nomes possuíveis ou intransitivos têm como determinante (dependente ou possuidor) o seu sujeito, o determinante dos transitivos é o seu objeto direto. Vejam-se os exemplos seguintes:

(136) a-j-potar né $\varnothing$-só- $\varnothing$

1SUJ-3OBJ-querer você CONT-ir-X

'quero que vás'

(137) sjé r-orí $\beta$ né $\varnothing$-só- $\varnothing \quad$ r-esé

eu CONT-alegria você CONT-ir-X CONT-por

'folgo que vás', lit: 'eu estou alegre pela ida de você'

(138) sjé r-orí-kaú né r-úr-a Ø-rí

eu CONT-alegria-bondade você CONT-vir-X CONT-por

'eu me alegro muito pela vinda de você (ou: por você ter vindo, ou: porque você veio)

(139) né r-úr-a sjé $\emptyset$-mo-orí $\beta$

você CONT-vir-X eu CONT-CAUS-alegria

'a vinda de você me alegrou'

(140) sjé Ø-ma?enwár né r-úr-a r-esé

eu CONT-lembrança você CONT-vir-X CONT-por

'bem me lembro de vossa vinda', lit: 'eu tenho lembrança a vinda de você'

(141) n(a) a-j-potár-i né sjé r-ú $\beta$ - $a$ Ø-juká- $\varnothing$

não 1SUJ-3OBJ-querer-NEG você eu CONT-pai-X CONT-

matar-X

'não quero que tu mates a meu pai', lit: 'não quero a sua ação de matar o meu pai'

(142) ma?é-Ø amõ né $\varnothing$-kér-ipe ere-s-epják

coisa/animal-X algum você CONT-dormir-LOC 2SUJ-3OBJ-ver 
'você viu alguma coisa no seu sonho', lit: 'no dormir de você'

Conforme Rodrigues (1996, p. 65), em Tupinambá, há, portanto,

o emprego de nomes como predicados e o emprego de verbos como argumentos, e o processo morfológico em ambos os casos é a marcação de caso: com marcador casual, tanto nomes quanto verbos funcionam como argumentos; sem marcador casual, uns e outros funcionam como predicados. Embora o caso locativo pontual ocorra também com argumentos de base verbal, o caso mais geral para a marcação de argumentos é o que chamamos de caso argumental, comum a todas as principais funções argumentais: sujeito de verbo intransitivo, sujeito de verbo transitivo, objeto de verbo transitivo, possuidor, objeto de posposição.

O Tupinambá é, pois, uma língua cuja organização sintática repousa diretamente na distinção, por meio da marcação de caso, entre argumento e predicado.

A língua Nheengatú, variedade moderna da língua geral amazônica, teria se desenvolvido a partir do Tupinambá, língua da família Tupí-Guaraní, do subconjunto III. Atualmente, é falada no Alto rio Negro no noroeste da Amazônia do Brasil, por Baré, Baniwa e Werekena, povos que substituíram suas línguas tradicionais do grupo Arawak do norte pelo Nheengatú (CRUZ, 2011).

No Nheengatú, o sufixo - a já não possui mais valor morfológico (CRUZ, 2011, p. 115). No entanto, em trabalho desenvolvido por Cruz e Santos (2015), sobre os empréstimos lexicais do português para a Língua Geral, a análise dos dados sugere que o sufixo - $a$ ainda possuía valor morfológico (ou ainda não o perdera) em Língua Geral Brasílica (LGB).

Assim, Cruz e Santos (2015) sugerem que se pode pensar que as alterações e a epêntese $^{47}$, para a reestruturação silábica, da vogal /a/ no final dos vocábulos, não foram por acaso, mas, sim, possuem valor morfológico. O sufixo $-a$, portanto, foi inserido nos empréstimos de duas maneiras: (143) substituição de uma vogal do português e (144) epêntese em palavras que terminavam com sílabas com coda, ou seja, sílabas terminadas por consoante.

De acordo com as autoras, não pode passar despercebido o fato de que o exemplo <funil>, apresentado no exemplo em (144), que vira $\langle$ funir-a $>$, foi assim registrado no Dicionário Brasílico Português; mas foi registrado como <funil> no Vocabulário Português Brasílico. Outro vocábulo desse tipo é <tambor> que vira <tambor-a>, registrado

\footnotetext{
${ }^{47}$ Processo linguístico que consiste no acréscimo de fonemas a um vocábulo (CRUZ E SANTOS, 2015, p. 12). 64
} 
assim na primeira versão do Dicionário Português Brasílico, mas que permanece <tambor> no Vocabulário Português Brasílico:

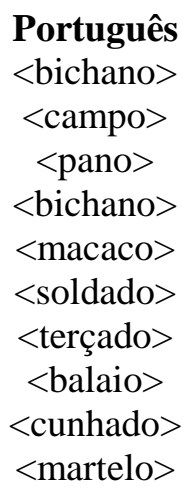

\section{LGB}

$\langle$ bixan-a>

$\langle$ kapin-a $>$

$\langle$ pan-a>

$\langle$ pixan-a>

$\langle$ macac-a $\rangle$

$\langle$ sorar-a>

$\langle$ traçar-a $>$

$\langle$ varai-a $>$

$<$ conhar-a $>$

$<$ marter-a $>$

(144)

$$
\begin{gathered}
\text { Português } \\
\text { <mãe> } \\
\text { <pai> } \\
\text { <altar> } \\
\text { <rei> } \\
\text { <cruz> } \\
\text { <papel> } \\
\text { <quintal> } \\
\text { <altar> } \\
\text { <funil> } \\
\text { <jantar> } \\
\text { <merendar> } \\
\text { <almoçar> } \\
\text { <tambor> }
\end{gathered}
$$

\subsection{O sufixo - $a$ não é um nominalizador}

Além do Nheengatu, em muitas outras línguas da FLTG o sufixo -a desapareceu completamente, ou ele permaneceu apenas associados à raiz. No entanto, no Tapirapé, no Guajá e no Tupinambá, a ocorrência desse sufixo é muito produtiva, o que pode estar relacionado com a forte omnipredicatividade dessas línguas.

Rodrigues (1953), Barbosa (1956) e Almeida, Irmãzinhas de Jesus e Paula (1983) analisaram o - $a$ como sendo um "nominalizador". Observando os exemplos de Rodrigues (1996), (145) e (146), percebe-se o sufixo - $a$ ocorrendo com nomes e verbos, uma vez que todas as entradas lexicais precisam recebê-lo para funcionarem como argumento:
(145) $x e=\varnothing-k y p y ' y r-a$
a-xaj'a
h-a-re
1SG.II=R-irmã-X 
'minha irmã chorou depois que ele foi embora'

(146)
xe= $\varnothing-x e^{\prime}$ eg-a mĩ i-ãrõãrõ
1SG.II=R-falar-X HAB 3.II-ser.bonita

'minha fala é sempre bonita'

É interessante perceber ainda que o mesmo verbo que ocorre como argumento, em (146), após receber o sufixo $-a$, pode também receber o sufixo nominalizador $\{-\tilde{a} w\}$ do Tapirapé, (147). Ao receber o - $\tilde{w} w$ uma ideia a mais, de "aspecto contínuo", agrega-se ao verbo, assim o que é traduzido como 'seu ato de falar' poderia ser compreendido também como 'sua falação':

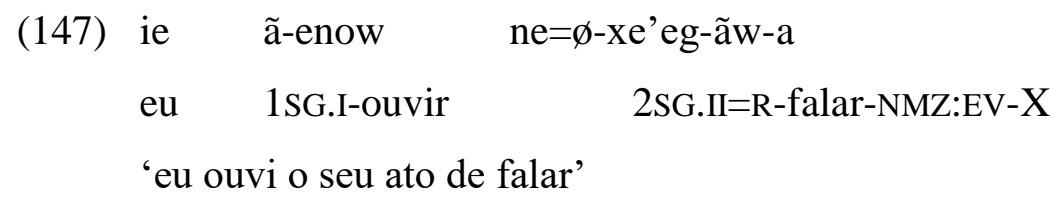

É possível sugerir, portanto, que verbos nominalizados também podem receber o sufixo - $a$. Se o receberem, vão funcionar como argumento; se não, funcionarão como predicado, assim sendo, percebe-se que o $-a$ age no campo sintático, não sendo um nominalizador. Por exemplo, em (148), a forma nominalizada $x e=r$-o'y-pepa-kyxi-ãw ocorre como um predicado existencial, que poderia ser traduzido como 'minha tesoura (existe)'. Pondendo receber ainda o receber o sufixo $-a$, tal como consta em (149):

(148) xe=r-o’y-pepa-kyxi-ãw

1SG.II=R-flecha-asa-cortar-NMZ:EV

'eu tenho uma tesoura' (lit. 'minha tesoura (existe)')

\footnotetext{
e-m-or=ãpy

ne=r-o'y-pepa-kyxi-ãw-ã

2SG.IMP-CAUS-vir=primeiro 1SG.II=R-flecha-asa-cortar-NMZ:EV-X

'me empresta sua tesoura, por favor'
}

Os dados revelam que nominalização, em Tapirapé, segue o conceito morfológico tradicional de transformar um verbo em um nome, entretanto a nominalização parece ser mais do que o resultado de processos morfológicos que possibilitam estruturas em 
que um verbo não caberia sintaticamente. Poderia ser um fenômeno léxico-gramatical, com implicações semânticas.

A nominalização estabeleceria ligação semântica com o verbo que lhe deu origem e características semânticas adicionais a fim de criar nomes para designar eventos, agentes, resultados, pacientes, instrumentos e assim por diante. Ou seja, em línguas como o Tapirapé, por exemplo, para colocar uma raiz verbal em posição argumental é necessário apenas um elemento do tipo - $a$; já quando se trata de acrescentar traços semânticos, precisa de morfologia adicional.

Tupinambá e Tapirapé são omnipredicativas, o que significa que todas as entradas lexicais são originalmente predicados. Nelas, portanto, o sufixo - a tem que ser combinado com uma entrada lexical para torná-lo capaz de referir e, assim, ocorrer como argumento, por exemplo. Por outro lado, o Nheengatú perdeu propriedades omnipredicativas, desse modo a separação entre nomes e verbos seria mais fácil de ser reconhecida: nomes são a única classe de palavras que podem ocorrer como argumentos, recebendo o $-a$, enquanto verbos seriam a classe de palavras com função de predicado, sem a marcação do $-a$. $\mathrm{O}$ fato de que os nomes também podem ocorrer como predicado é um vestígio do antigo padrão da língua.

Sugere-se que nominalizadores em línguas omnipredicativas têm uma função mais restrita: eles são usados para criar novas entradas lexicais que podem ocorrer como argumento ou predicado nominal. Essas são algumas evidências iniciais que possibilitam uma discussão interessante e, certamente, oportunizam futuras outras pesquisas. 


\section{CONSIDERAÇÕES FINAIS}

Nesta dissertação tive como objetivo apresentar a funcionalidade do sufixo - $a$ nas línguas Tapirapé, Guajá e Kamaiurá, da família linguística Tupí-Guaraní, e refletir acerca da relação nome/verbo-argumento/predicado e da omnipredicatividade. O estudo realizado sugere algumas constatações, no entanto aponta principalmente para a demanda de se realizarem outras pesquisas que investiguem fenômenos também interessantes entre línguas da FLTG.

A produção de pesquisas e a documentação de línguas da FLTG são reconhecidas na tradição histórica dos estudos linguísticos sobre línguas indígenas. Entretanto, após realizar uma pesquisa de cunho bibliográfico, constato que os trabalhos disponíveis são, em sua maioria, descrições morfossintáticas abrangentes que constituem praticamente o único inventário documental dessas línguas, restritas, muitas vezes, aos mesmos autores. Desse modo, devemos incentivar outros estudos, reconhecendo as especificidades indígenas, uma vez que poderão fomentar iniciativas de manutenção da língua e dos valores culturais desses povos, sobretudo nas escolas indígenas já existentes em algumas das comunidades.

Ao longo da pesquisa, percebeu-se que o sufixo - $a$ e suas funções tem sido descrito de diferentes maneiras nos estudos sobre as línguas da FLTG, sendo este o X da questão.

Rodrigues (2001) referiu-se ao sufixo - $a$ como "caso argumentativo", isso porque a função de habilitar lexemas como nomes não pode ser atribuída ao - $a$ nesta língua já que ele não ocorre em temas não-nominais e, mesmo um nome sem tal sufixo, funcionando como predicado ou vocativo, continua sendo um nome. Porém, considerando os dados do Guajá, essa não seria a melhor designação. Neste outra língua, os dados de Magalhães (2007) revelam um relação oposta, em que apenas as palavras lexicais identificadas como nomes é que podem receber o sufixo, outras não. Sem o sufixo, esses nomes exercem "função sintática de vocativo, complementos circunstanciais ou núcleos de predicados existenciais" (MAGALHÃES, 2007, p. 145). Também não se pode caracterizá-lo como um sufixo cuja função é a de habilitar um nome como argumento, pois há argumentos que não ocorrem marcados por este morfema e ele ocorre também em nomes que estão em função não argumental.

"Sufixo nominal" (BARBOSA, 1956) ou "caso nominal” (MAGALHÃES, 2007) não seriam também as designações mais adequadas para o sufixo $-a$, visto que no 68 
Tapirapé os verbos também podem receber o $-a$, desempenhando as funções de argumento único de verbo descritivo ou intransitivo e podendo ser objeto de transitivos. A denominação “caso nuclear" (SEKI, 2001) talvez não seja a que melhor descreve as funções deste sufixo no Kamaiurá, já que ele ocorre também associado a nomes que não funcionam como núcleo, como os objetos das posposições, por exemplo.

Observando os dados, considero que a interpretação mais adequada para denominar o sufixo - a seria a de Queixalós (2006) que o interpreta como um sufixo capaz de atribuir à raiz a que se liga a capacidade de criar referência, e o denomina "referenciante". A função básica deste marcador não é a de transformar um predicado em argumento, ou de subordinar um predicado a outro, mas de construir um referente em uma raiz que por si só seria incapaz de referir, dada sua natureza predicativa.

No Capítulo 1, percebemos comunidades e línguas indígenas em situações diversas: algumas muito vivas e promovendo ações protetoras dos aspectos culturais e linguísticos de seu povo, até o outro extremo, povos que não têm mais a língua indígena como língua materna ou língua de interações espontâneas. Vimos que as práticas de etnocídio e genocídio são seriamente responsáveis pelo desaparecimento de centenas de comunidades indígenas, e que, infelizmente, essas práticas persistem ainda hoje, em certos momentos e em determinadas regiões com maior intensidade.

No Capítulo 2, constata-se que a identificação das classes de nomes e verbos nas línguas pesquisadas constitui-se a partir de critérios morfológicos bem delimitados e específicos para cada uma delas. De modo geral, são utilizados critérios morfológicos, como a possibilidade de receber afixos, como prefixos de tempo e aspecto, prefixos pessoais, sufixos de nominalização, sufixos casuais, entre outros.

Ainda no Capítulo 2, percebe-se que a classe dos adjetivos é analisada e se comporta de maneiras diferentes na literatura da FLTG: no Tapirapé, os verbos descritivos são os responsáveis por exprimir conceitos que denotam qualidades; no Guajá, identifica-se a classe dos adjetivos, sendo que esta compartilha mais características de verbos do que de nomes; e, no Kamaiurá, os verbos descritivos assim são tratados por não deterem propriedades morfológicas e sintáticas específicas que justifiquem seu tratamento como uma classe separada "adjetivos".

No Capítulo 3, discutiu-se o quão importante é a predicação, pois é por meio dela que se expressa um argumento e se atribuem propriedades, qualidades, estados e ações a ele. Desse modo, foi possível compreender que o adjetivo, originalmente, entrava na categoria 
do predicado, portanto do verbo. No estudo da omnipredicatividade, dados da língua Nahuatl demonstraram que, nela, a função predicativa não é exclusiva de verbos, assim a função predicativa não poderia ser considerada como um critério de demarcação entre as classes de nomes e verbos. Esse comportamento também pôde ser observado em línguas da FLTG, em que se percebeu o sufixo - $a$ como sendo o responsável por expressar a função predicativa, quando não expresso, e a função argumental, quando expresso — sendo esta última uma função secundária. Tendo apresentado alguns pontos relevantes sobre o histórico do sufixo - $a$, considera-se que ele era onipresente em uma dada época além do proto-Tupí-Guaraní e, desde então, só fez regredir até desaparecer totalmente em algumas línguas.

No Capítulo 4, constatou-se que:

(i) apesar de ter um comportamento homogêneo, o sufixo - a é nomeado de maneiras diferentes pelos especialistas de cada língua;

(ii) no Tapirapé, nomes e verbos podem receber o sufixo - $a$. Quando essas raízes o recebem, podem desempenhar as funções expostas na Tabela 5;

\begin{tabular}{|c|c|}
\hline Nomes marcados com o sufixo $-a$ & Verbos marcados com o sufixo - $a$ \\
\hline Sujeito e objeto de verbo transitivo & \multirow{2}{*}{$\begin{array}{l}\text { Argumento único de verbo descritivo } \\
\text { ou intransitivo }\end{array}$} \\
\hline Argumento único de intransitivo & \\
\hline Complemento de posposição & \multirow[b]{2}{*}{ Objeto de transitivo } \\
\hline $\begin{array}{l}\text { Ocorrem como núcleo de predicados } \\
\text { em orações nominais } \\
\text { equativas/inclusivas }\end{array}$ & \\
\hline
\end{tabular}

Tabela 5. Funções para nomes e verbos do Tapirapé quando marcados com - $a$.

(iii) no Kamaiurá, nomes podem receber o sufixo - $a$. Quando essa raiz o recebe, pode desempenhar as funções expostas na Tabela 6;

\begin{tabular}{|l|}
\hline \multicolumn{1}{|c|}{ Nomes marcados com o sufixo $-\boldsymbol{a}$} \\
\hline Sujeito de predicados verbais e não verbais \\
\hline Objeto de verbos e posposições \\
\hline Modificador (possuidor) na locução genitiva \\
\hline Complemento de cópula \\
\hline Predicado nominal \\
\hline Nome núcleo modificado por outro nome não possível \\
\hline Possuído prefixado com marcador de possuidor indefinido de terceira pessoa \\
\hline
\end{tabular}


Tabela 6. Funções para nomes do Kamaiurá quando marcados com - $a$.

(iv) no Guajá, nomes podem receber o sufixo - $a$. Quando essa raiz o recebe, pode desempenhar as funções dispostas na Tabela 7;

\begin{tabular}{|l|}
\hline \multicolumn{1}{|c|}{ Nomes marcados com o sufixo $-\boldsymbol{a}$} \\
\hline Sujeito de predicados verbais \\
\hline Sujeito de predicados adjetivais \\
\hline Sujeito de predicados nominais \\
\hline Objeto de predicados verbais \\
\hline $\begin{array}{l}\text { Nomes que se referem aos argumentos nucleares, mas que exercem funções } \\
\text { não argumentais }\end{array}$ \\
\hline Nomes com função de aposto explicativo \\
\hline Nomes com função de núcleos de predicados equativos \\
\hline
\end{tabular}

Tabela 7. Funções para nomes do Guajá quando marcados com - $a$.

(v) o sufixo - $a$ não promove mudança de classe lexical, já que nomes e verbos podem ser combinados a ele;

(vi) no Tapirapé, observa-se uma maior ocorrência da variedade [ã] na fala dos mais velhos e, na fala dos mais jovens, ocorre a variante [a], que em determinadas falas é quase inaudível. No Kamaiurá, na fala, principalmente quando mais rápida, o sufixo não se realiza foneticamente, quando acrescentado a radicais terminados em 'a' tônico e quando é imediatamente seguido por palavras iniciadas em vogal átona. No Guajá, em fala rápida, o sufixo - $a$ não se realiza foneticamente quando o tema por ele flexionado é seguido por uma vogal átona inicial;

(vii) no Tapirapé, no Kamaiurá e no Guajá, vocativos não recebem o sufixo - $a$;

(viii) analisando dados das orações equativas/inclusivas, percebem-se indícios da existência de dois tipos de predicação, com e sem a marcação do sufixo - $a$. Tapirapé e Guajá se assemelham, por terem nome marcado pelo - $a$ como um possível referenciante. Já no Kamaiurá, o nome está na função de predicado, sem o sufixo $-a$;

(ix) o sufixo - $a$ estabelece uma expressão que pode constituir referências em raízes que não podem referir-se por si mesmas, uma vez que são essencialmente predicativas; 
(x) no Tapirapé, no Kamaiurá e no Guajá, dados revelam o sufixo -a marcando nomes próprios, demonstrativos e pronomes. Esse fenômeno é curioso, pois são expressões naturalmente referenciantes. Assim, ainda são necessárias maiores investigações para buscar evidências que expliquem essa possibilidade de ocorrência do sufixo $-a$;

(xi) no Tupinambá, o $-a$ se mostrava bastante produtivo, podendo nomes e verbos recebê-lo para funcionarem como argumento e, quando não o recebem, funcionam como predicados. No Nheengatú, o sufixo - a não é mais produtivo, deixando, no entanto, evidências de sua existência nos empréstimos lexicais do português;

(xii) o sufixo - $a$ não seria um nominalizador, uma vez que verbos no Tapirapé, por exemplo, com o sufixo nominalizador - $\tilde{w} w$, também podem receber o sufixo - $a$. Os processos de nominalização são inerentemente predicados.

Essas constatações, na verdade, não são considerações finais, mas, sim, iniciais de um futuro percurso maior e ainda cheio de possibilidades de análises e descobertas. Há a necessidade de aprofundar os estudos sobre o percurso histórico do sufixo - $a$, coletar mais dados para a investigação de sua funcionalidade quanto às orações equativas e sua marcação em nomes referenciantes por natureza e expandir a quantidade de línguas analisadas. Esses são alguns próximos passos interessantes na continuação dos estudos da morfossintaxe da FLTG. 


\section{REFERÊNCIAS BIBLIOGRÁFICAS}

ALMEIDA, A.; IRMÃNZINHAS DE JESUS \& PAULA, L. G. A língua Tapirapé. Rio de Janeiro: Xerox do Brasil, 1983.

ANCHIETA, J. de. Arte de Gramática da Língua mais usada na costa do Brasil. Coimbra: Antônio de Mariz. Disponível em: http://biblio.etnolinguistica.org/anchieta-1595-arte, 1595. Acesso em: 12 jun. 2016.

BARBOSA, Pe. A. Lemos. Curso de Tupi Antigo. Gramática, Exercícios, Textos. Rio de Janeiro: Livraria São José, 1956.

BENVENISTE, E. Problemas de Linguística Geral I. 4. ed., Campinas: Pontes, 1995.

BORGES, M. V. Aspectos fonológicos e morfossintáticos do Avá-Canoeiro (Tupi-Guaraní). 2006. Tese (Doutorado em Linguística) - Instituto de Estudos da Linguagem, Universidade Estadual de Campinas, Campinas, 2006.

CABRAL, A. S. A. C. Observações sobre a história do morfema -a da família. In QUEIXALÓS, F. (ed), Des noms et des verbes en Tupi-Guarani: état de la question. Muechen: Lincom Europa, Lincom Studies in Native American Linguistics 37, p. 33-62, 2001.

CAVALCANTE FILHO, F. de A. V. Os problemas da opinião falsa e da predicação no diálogo sofista de Platão. 2013. Tese (Doutorado em Filosofia) - Programa Interinstitucional de Doutorado em Filosofia (PIDFIL), Universidade Federal da Paraíba, João Pessoa, 2013.

CLASTRES, P. Arqueologia da violência: pesquisas de antropologia política. São Paulo: Editora Cosac \& Naify, 2004.

COMRIE, B. Language Universals and Linguistic Typology (Syntax and Morphology). Chicago: University of Chicago Press, 1981.

CORRÊA DA SILVA, B. C. Mawé/Awentí/Tupí-Guaraní: Relações linguísticas e implicações históricas. 2010. Tese (Doutorado em Linguística) - Instituto de Letras, Universidade de Brasília, Brasília, 2010.

CRUZ, A. A Fonologia e Gramática do Nheengatú: A língua geral falada pelos povos Baré, Warekena e Baniwa. Tese de Doutorado, Vrije Universiteit, Amsterdam, 2011.

CUNHA, M. A. F. da. et. al. Pressupostos teóricos fundamentais. IN: CUNHA. M. A. F da et. al. Linguística funcional: teoria e prática. Rio de Janeiro: DP \& A, p. 29 - 55, 2003

CURI, M. V. Antropologia Jurídica: um estudo do direito Kamaiurá. 2011. Tese (Doutorado em Ciências Sociais) - Pontifícia Universidade Católica de São Paulo, São Paulo, 2011.

DELANCEY, S. Lectures on Functional Syntax. [S/1]: University of Oregon, 2000.

DIETRICH, W. O tronco tupí e as suas famílias de línguas: Classificação e esboço tipológico. In: NOLL, V.; DIETRICH, W. (Org.). O Português e o Tupí no Brasil. São Paulo: Contexto, cap. 1, p. 23, 2010. 
DILLINGER, M. Forma e função na Linguística. DELTA, v. 7, n. 1, p. 397-407, São Paulo, 1991.

DIXON, R. Where have all adjectives gone? Studies in Language, vol 1., ed. 1., p. 1-80, 1977.

FERNANDES, F. A organização social dos Tupinambá. São Paulo: Instituto Progresso Editorial, 1948.

FERREIRA DA COSTA, F. V. Revitalização e ensino de língua indígena: interação entre sociedade e gramática. 2013. Tese (Doutorado em Linguística) - Faculdade de Ciências e Letras, Universidade Estadual Paulista, São Paulo, 2013.

GIVÓN, T. Functionalism and Grammar. Amsterdam/Filadélfia: John Benjamins Publishing Company, 1995.

. Syntax: a functional-typological introduction. Vol. I e II. Amsterdam/Philadelphia: John Benjamins Publishing Company, 2001.

GOMES, D. Estudo morfológico e sintático da língua Mundurukú (Tupí). 2006. Tese

(Doutorado em Linguística) - Instituto de Letras, Universidade de Brasília, Brasília, 2006.

HOPPER, P. J. Emergent Grammar. Berkeley Linguistic Society, 1987.

. Emergent Grammar and the Apriori Grammar Postulate. In: D. Tannen (ed.).

Linguistic in Context: Connecting Observation and Understanding. Norwood: Ablex, p. 117134, 1988.

HOPPER, P.J. \& THOMPSON, S.A. The discourse basis for lexical categories in universal grammar. Language, p. 703-752, 1984.

JENSEN, C. O desenvolvimento histórico da língua Wayampi. Série Línguas Indígenas. Campinas: Editora da Unicamp, 1989.

JUNQUEIRA, C. Dinâmica Cultural. In: Revista de Estudos e Pesquisas, Ministério da Justiça, Fundação Nacional do Índio, Coordenação Geral de Estudos e Pesquisas, v. 1, n. 1, Brasília, jul. de 2004.

KAMAIWRÁ, A. P. Uma análise linguístico-antropológico de exemplares de dois gêneros discursivos kamaiurá. 2010. Dissertação (Mestrado em Linguística) - Instituto de Letras, Universidade de Brasília, Brasília, 2010.

LAKATOS, E. M.; MARCONI, M. A. Fundamentos de metodologia científica. 3. ed. revisada e ampliada. São Paulo, Atlas: 1991.

LAUNEY, M. Catégories et opérations dans la gramaire nahuatl. Thèse d'Etat, Paris: Université de Paris IV, 1986.

2004.

The features of omnipredicativity in Classical Nahuatl. STUF, n. 57, vol. I. Berlin, 
MAGALHÃES, M. M. S. Sobre a morfologia e a sintaxe da língua Guajá (Família TupíGuaraní). 2007. Tese (Doutorado em Linguística) - Instituto de Letras, Universidade de Brasília, Brasília, 2007.

MATTOS, A. C. R. A cisão intransitiva em línguas da família Tupi-Guarani. 2015. Dissertação (Mestrado em Linguística) - Instituto de Letras, Universidade de Brasília, Brasília, 2015.

MELLO, A. A. S. Estudo Histórico da Família Lingüística Tupi-Guarani: aspectos fonológicos e lexicais. 2000. Tese de Doutorado. Santa Catarina, UFSC, 2000.

MONTSERRAT, T. M. F. Línguas Indígenas no Brasil Contemporâneo. In: GRUPIONI, L. D. B. Índios no Brasil (org). 4ed. São Paulo: lobal, Brasília: MEC, 2000.

MUSSALIN, F.; BENTES, A. C. (orgs.) Introdução à linguística: fundamentos epistemológicos, v. 3. São Paulo: Cortez, 2004.

NOELLI, F.S.. As hipóteses sobre o centro de origem e rotas de expansão dos Tupí. Revista de Antropologia. v. 39, p. 7-56. São Paulo, 1996.

PAYNE, T. E. Exploring Language Structure. . Cambridge: Cambridge University Press, 2006.

PRAÇA, W. N. A dupla oposição nome/verbo e argumento/predicado em Tapirapé. Universidade Católica de Brasília (UCB). Brasília, 2006. UnB, 1999.

Nomes como predicados na língua Tapirapé. Dissertação de Mestrado. Brasília, Morfossintaxe da língua Tapirapé. Tese de Doutorado. Brasília, UnB, 2007.

QUEIXALÓS, F. Des noms et des verbes en Tuoi-Guarani: état de la question. Munique: Lincom Europa, 2001a.

. Le suffixe référentiant en émérillon\| in Queixalós, F. (resp.), p. 117-132, 2001b. 422, 1998.

Nom, Verbe et Prédicat en Sikuani (Colombie). Paris: Éditions Peeters/SELAF., p.

The primacy and fate of predicativity in Tupi-Guarani. In LOIS, X. \&

VAPNARSKY, V. (eds.). Root classes and lexical categories in Amerindian languages, p. 249-287. Vienne, Peter Lang, 2006.

RODRIGUES, A. D. A categoria de voz em Tupi. Logos 6, p. 50-53. Curitiba, 1947.

A originalidade das línguas indígenas brasileiras [conferência realizada na inauguração do Laboratório de Línguas Indígenas da Universidade de Brasília, em 08 de julho de 1999]. Brasília, DF: Laboratório de Línguas Indígenas, 1999. Disponível em: http://www.laliunb.com.br. Acesso em: 16 de novembro de 2014

Argumento e predicado em Tupinambá. Abralin - Boletim da Associação Brasileira de Linguística 19, p.57-66. Maceió, 1996. 
As Línguas Gerais Sul-Americanas in Papia, Revista de Crioulos de Base Ibérica, vol 4, no. 2. Brasília, 1996.

Estrutura do Tupinambá. Notas do curso dado na Universidade Estadual de Campinas (UNICAMP). Inédito, 1981.

. Evolução e expansão das variedades Tupí no Brasil: O Tupí, o Tupinambá e o Português do Brasil, UnB. Brasília 2010.

. Línguas Brasileiras. Para o Conhecimento das Línguas Indígenas, Ed. Loyola, São Paulo, 1986.

. Línguas indígenas: 500 anos de descobertas e perdas. D.E.L.T.A. 91:83-103. São

Paulo, 1993a.

. Línguas indígenas: 500 anos de descobertas e perdas. Ciência Hoje. 95:20-26. Rio de Janeiro, 1993b.

. Morfologia do verbo Tupi. Letras, p.121-152, Brasil, 1953.

. Relações internas na família linguística Tupi-Guarani. Revista Brasileira de Antropologia. v. 27/28, São Paulo: USP, p. 33-53, 1984/1985.

. Relações internas na família linguística Tupi-Guarani. Revista Brasileira de Linguística Antropológica. v. 3, nº 2, Dezembro, 2011.

. Sobre a Natureza do Caso Argumentativo. In QUEIXALÓS, F. (ed) Des noms et des verbes en Tupi-Guarani: état de la question. Muniqe: Lincom Europa, p. 103 - 114, 2001.

ROSE, F. Morphosyntaxe de L'Emerillon: Langue tupi-guarani de Guyane française. Tese de doutorado. Universidade Lumière Lyon 2, 2003.

SCHACHTER, P. Parts-of-speech systems. In SHOPEN, T. (ed.). Language typology and syntactic description, vol. I: Clause Structure. Cambridge: Cambridge University Press, 1985.

SEKI, L. Gramática do Kamaiurá São Paulo, Editora de Unicamp. São Paulo, 2000.

. Kamaiurá (Tupí-Guaraní) as an Active-Stative Language, in Payne, E. (ed.), Amazonian Linguistics, Studies in Lowland South American Languages Austin U. of Texas Press, p. 367 - 391, 1990.

SOUZA, E. C. de. A teoria das formas de Platão. Temas \& Matizes, v. 4, p. 82- 88, 2005

STADEN, H. Duas viagens ao Brasil. Tradução de Angel Bojadsen. Porto Alegre, RS: L\&PM, 2009.

VIEIRA, M. D. O problema da configuracionalidade na língua Asurini: uma consequência da projeção dos argumentos do predicado verbal. Tese de Doutorado, Campinas:

UNICAMP/IEL, 1993. 